University of Nebraska - Lincoln

DigitalCommons@University of Nebraska - Lincoln

September 2002

REVISION OF THE SOUTHERN SOUTH AMERICAN ENDEMIC GENUS AULACOPALPUS Guérin-Méneville WITH PHYLOGENETIC AND BIOGEOGRAPHIC ANALYSES OF THE SUBTRIBE BRACHYSTERNINA (COLEOPTERA: SCARABAEIDAE: RUTELINAE: ANOPLOGNATHINI)

Andrew Smith

asmith@unl.edu

Follow this and additional works at: https://digitalcommons.unl.edu/entomologypapers

Part of the Entomology Commons

Smith, Andrew, "REVISION OF THE SOUTHERN SOUTH AMERICAN ENDEMIC GENUS AULACOPALPUS Guérin-Méneville WITH PHYLOGENETIC AND BIOGEOGRAPHIC ANALYSES OF THE SUBTRIBE BRACHYSTERNINA (COLEOPTERA: SCARABAEIDAE: RUTELINAE: ANOPLOGNATHINI)" (2002). Papers in Entomology. 17.

https://digitalcommons.unl.edu/entomologypapers/17

This Article is brought to you for free and open access by the Museum, University of Nebraska State at DigitalCommons@University of Nebraska - Lincoln. It has been accepted for inclusion in Papers in Entomology by an authorized administrator of DigitalCommons@University of Nebraska - Lincoln. 


\title{
Revision of the Southern South American Endemic Genus aulacopalpus Guérin-Méneville with Phylogenetic and Biogeographic Analyses of the Subtribe Brachysternina (Coleoptera: Scarabaeidae: Rutelinae: Anoplognathini)
}

\author{
ANDREW B. T. SMITH \\ W436 Nebraska Hall \\ Division of Entomology \\ University of Nebraska State Museum \\ Lincoln, NE 68588-0514, U.S.A. \\ asmith@unlserve.unl.edu
}

\begin{abstract}
Phylogenetic analyses were performed on the 17 taxa in the subtribe Brachysternina (Coleoptera: Scarabaeidae: Rutelinae: Anoplognathini) as a means of resolving classification conflicts and of identifying monophyletic groups. Results demonstrated that the subtribe is monophyletic and is composed of three monophyletic genera: Aulacopalpus Guérin-Méneville (nine species), Brachysternus Guérin-Méneville (seven species), and Hylamorpha Arrow (one species). Characters that define the genera are discussed, and the biogeography of the group is discussed.

The genus Aulacopalpus is revised and now includes A. aconcaguensis new species, A. castaneus (Laporte), A. ciliatus (Solier), A. clypealis Ohaus, A. pilicollis (Fairmaire), A. punctatus (Fairmaire and Germain), A. pygidialis Ohaus, A. valdiviensis new species, and A. viridis Guérin-Méneville. The generic name Tribostethes Curtis is placed in synonymy with the valid name Aulacopalpus Guérin-Méneville; the species name Aulacopalpus fulvovirens Ohaus is placed in synonymy with the valid name Aulacopalpus castaneus (Laporte); the species name Amblyterus variabilis Philippi is placed in synonymy with the valid name Aulacopalpus punctatus (Fairmaire and Germain); and the species name Aegolasia michaelseni Kolbe is placed in synonymy with the valid name Aulacopalpus pilicollis (Fairmaire). Aulacopalpus viridis Guérin-Méneville is designated as the type species for the generic name Amblyterodes Germain. Phytholaema herrmanni herrmanni Germain is designated as the type species for the generic name Melicurus Germain, and the genus is transferred from the Brachysternina to the tribe Xylonychini (Scarabaeidae: Melolonthinae) as a junior synonym of the genus Phytholaema Blanchard. A lectotype is designated for each of the following names: Amblyterus variabilis Philippi, Aulacopalpus clypealis Ohaus, Aulacopalpus fulvovirens Ohaus, Aulacopalpus pygidialis Ohaus, Bembegeneius fulvescens Solier, Tribostethes ciliatus Solier, and Tribostethes pilicollis Fairmaire. A neotype is designated for Aegolasia michaelseni Kolbe, Aulacopalpus viridis Guérin-Méneville, Brachysternus castaneus Laporte, Tribostethes punctatus Fairmaire and Germain, and Tribostethes virens Philippi and Philippi. Descriptions of all species are included. A key to the genera of Neotropical Anoplognathini and species in the genus Aulacopalpus is provided.
\end{abstract}

\section{Resúmen}

Se presenta un análisis filogenético de los 17 taxa de la subtribu Brachysternina (Coleoptera: Scarabaeidae: Rutelinae: Anoplognathini). Este estudio se desarrolló con el fin de resolver los conflictos de clasificación de la subtribu, y para la identificación de grupos monofiléticos. Los resultados demuestran que la subtribu es monofilética, y que está compuesta de tres géneros monofiléticos: Aulacopalpus Guérin-Méneville (nueve especies), Brachysternus Guérin-Méneville (siete especies), e Hylamorpha Arrow (una especie). Los caracteres que definen los géneros y la biogeografía del grupo son discutidos en este artículo.

Se revisa el género Aulacopalpus, que ahora incluye las siguientes especies: A. acon- 
caguensis nueva especie, A. castaneus (Laporte), A. ciliatus (Solier), A. clypealis Ohaus, A. pilicollis (Fairmaire), A. punctatus (Fairmaire and Germain), A. pygidialis Ohaus, A. valdiviensis nueva especie, y A. viridis Guérin-Méneville. El nombre genérico Tribostethes Curtis se reconoce como sinónimo del nombre válido Aulacopalpus Guérin-Méneville; el nombre específico Aulacopalpus fulvovirens Ohaus es puesto en sinonimia con el nombre válido Aulacopalpus castaneus (Laporte); el nombre específico Amblyterus variabilis Philippi es puesto en sinonimia con el nombre válido Aulacopalpus punctatus (Fairmaire y Germain); y el nombre específico Aegolasia michaelseni Kolbe se reconoce como sinónimo de Aulacopalpus pilicollis (Fairmaire). Se designa a Aulacopalpus viridis Guérin-Méneville como la especie tipo para el nombre genérico Amblyterodes Germain. Phytholaema herrmanni herrmanni Germain es designada como especie tipo para el nombre genérico Melicurus Germain; y este género es transferido de Brachysternina a la tribu Xylonychini (Scarabaeidae: Melolonthinae) como sinónimo junior del género Phytholaema Blanchard. Se designa lectotipo para cada uno de los siguientes nombres: Amblyterus variabilis Philippi, Aulacopalpus clypealis Ohaus, Aulacopalpus fulvovirens Ohaus, Aulacopalpus pygidialis Ohaus, Bembegeneius fulvescens Solier, Tribostethes ciliatus Solier, y Tribostethes pilicollis Fairmaire. Se designa neotipo para Aegolasia michaelseni Kolbe, Aulacopalpus viridis Guérin-Méneville, Brachysternus castaneus Laporte, Tribostethes punctatus Fairmaire y Germain, y Tribostethes virens Philippi y Philippi. Se incluyen descripciones de todas las especies. Se presenta una clave para los géneros neotropicales de Anoplognathini, y para las especies del género Aulacopalpus.

The Anoplognathini is one of six tribes (Rutelini, Anomalini, Spodochlamyini, Geniatini, Adoretini, and Anoplognathini) in the subfamily Rutelinae (Coleoptera: Scarabaeidae). Anoplognathini contains five subtribes: Anoplognathina and Schizognathina occur in Australia and New Guinea, and Phalangogoniina, Platycoeliina, and Brachysternina occur in the Neotropics. The subtribe Brachysternina is endemic to southern South America, ranging from the Chilean province of Coquimbo south through Chile and Argentina to Tierra del Fuego. There are three genera in the Brachysternina (Fig. 1): Aulacopalpus Guérin-Méneville (nine species), Brachysternus Guérin-Méneville (seven species), and Hylamorpha Arrow (one species). Phylogenetic analyses of the Brachysternina will help to resolve classification conflicts, identified monophyletic groups, and identified sister groups. The Brachysternina is a neglected group with poorly defined genera that have not been treated taxonomically in almost a century. As a result, there is no reliable means of identification for the species and many synonymous names are currently used. The main purpose of this paper is to revise the genus Aulacopalpus and present a cladistic analysis, biogeographic analysis, and catalog of the subtribe Brachysternina.

This paper is the third in a series of three in this issue of the Coleopterists Bulletin that revises the subtribe Brachysternina. The first part is a revision of Brachysternus by Jameson and Smith (2002). The second is a revision of Hylamorpha by Ratcliffe and Ocampo (2002).

\section{Phylogenetic Analysis of the Brachysternina}

Reconstruction of the phylogeny of the Brachysternina was performed using 45 adult morphological characters. I examined characters from different parts of the body to minimize the significance or bias of any one region. The character matrix used in the phylogenetic analysis is constructed using MacClade version 4.0 (Maddison and Maddison 2000) and analyzed using PAUP* version 4.0 (Swofford 2000). Species from the two other genera of Neotropical Ano- 
plognathini are used as outgroups: Phalangogonia sperata Sharp, Platycoelia lutescens Blanchard, and Platycoelia humeralis Bates. These genera are closely related to the Brachysternina and share many character states relative to other Rutelinae and Anoplognathini. The characters and character states used in the analyses are discussed below. See appendix 1 for the character matrix.

\section{Adult Morphological Characters}

\section{Mouthparts}

1. Mandibular molar region with lamellae well developed (0) or reduced (1).

2. Maxilla with toothed ridge at apex reduced (0), with one ridge (1), with two ridges (2), or with three ridges (3).

3. Terminal segment of maxillary palpus parallel sided (0) or widest near base (1).

4. Terminal segment of maxillary palpus with sulcus elongated (0) or suboval (1).

5. Mentum with apex reduced and truncate $(0)$ or elongated and reflexed into oral cavity (1).

\section{Head}

6. Clypeal apex rounded (Figs. 3-5) (0) or rectangular (1)

7. Clypeal margin reflexed (0) or not reflexed (1)

8. Head densely punctate (0), moderately punctate (1), or sparsely punctate (2) (see Methods and Materials: Taxonomic Characters for definitions).

9. Head densely setose (0), sparsely setose (1), or glabrous (2).

10. Interocular width in males greater than two eye-widths $(0)$ or less than two eye-widths (1).

11. Head between base and eye (see Jameson and Smith [2002] for illustration) glabrous (0), with hair-like setae (1), or with scale-like setae (2).

12. Antennal club length in males shorter (Fig. 5) (0) or subequal to head length (Fig. 4) (1).

\section{Pronotum}

13. Color light brown (0), greenish brown (1), chestnut brown (2), green (3), or cream (4).

14. Surface densely punctate (0), moderately punctate (1), or sparsely punctate (2) (see Methods and Materials: Taxonomic Characters for definitions).

15. Surface densely setose (0), sparsely setose (1), or glabrous (2).

\section{Elytron}

16. Color light brown (0), greenish brown (1), chestnut brown (2), green (3), cream (4).

17. Surface densely setose (0), sparsely setose (1), or glabrous (2).

18. Striae indistinct (0), punctate (1), or impressed (2).

19. Margin membranous (0) or not membranous (1).

\section{Hind Wing}

20. Setae along apical half of leading edge absent (0) or present (1).

21. Vein $\mathrm{AA}_{1+2}$ (see Jameson 1998 for illustration) short (0) or elongated (1). 

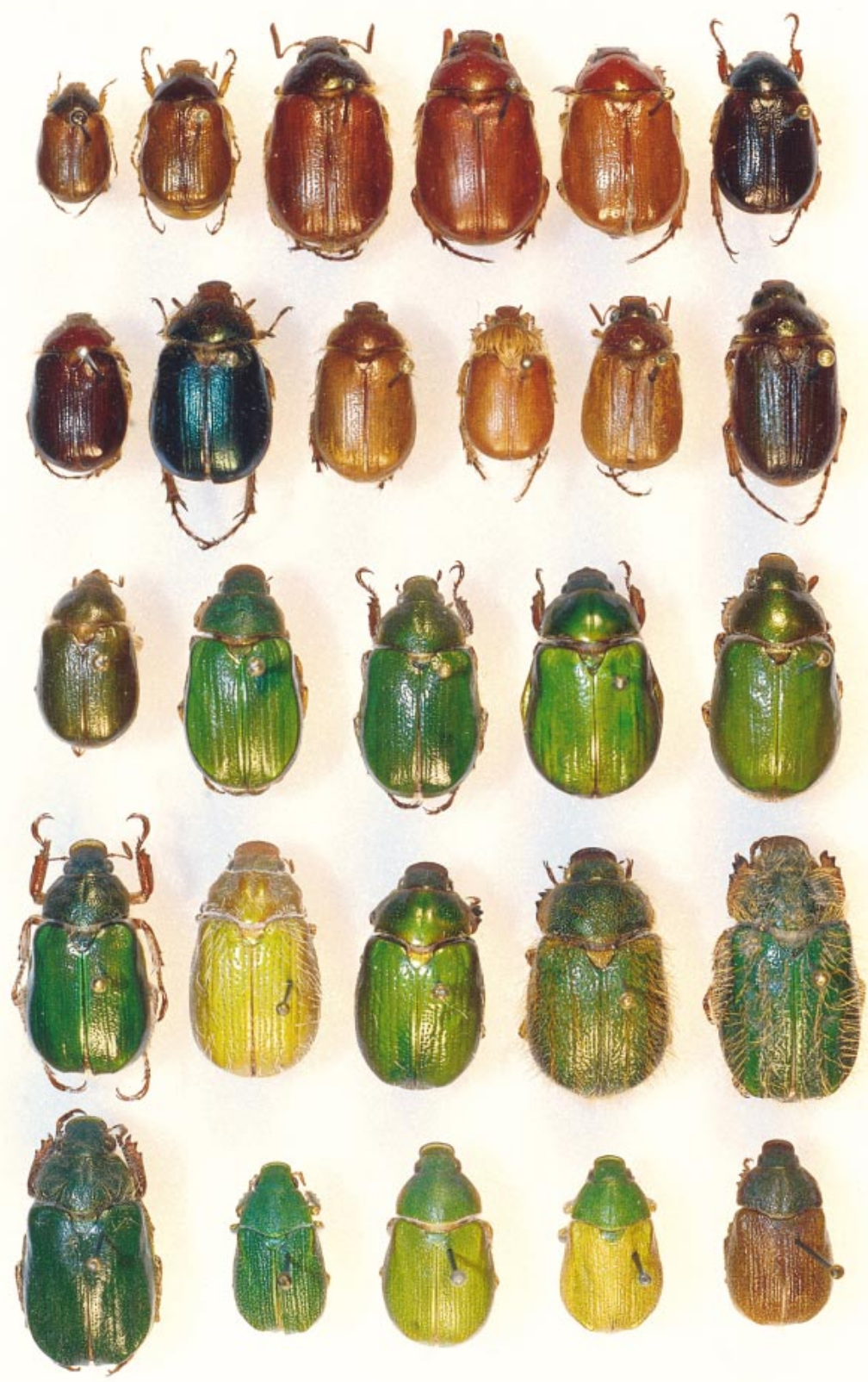

Fig. 1. The Brachysternina. First row: Aulacopalpus aconcaguensis (male paratype), A. aconcaguensis (male paratype), A. castaneus (male), A. castaneus (male), A. castaneus (male), A. punctatus (male). Second row: A. ciliatus (male), A. clypealis (male), 


\section{Pygidium}

22. Surface with hair-like setae (0), scale-like setae (1), glabrous (2), or thickened setae (3).

23. Surface in females convex (0), indented (1), or flattened (2).

\section{Venter}

24. Metathoracic process barely produced (0), elongated to procoxae (1), or absent (2).

25. Abdonimal sternites with setae indistinct (0) thickened setae (1), scalelike setae (2), or hair-like setae (3).

26. Terminal spiracle with longitudinal groove on ventral side $(0)$ or without longitudinal groove on ventral side (1).

27. Terminal abdominal sternite with apex in females evenly rounded (0), flattened (1), strongly emarginate (2), weakly emarginate (3).

Legs

28. Protibia with inner, apical spur (0) or without spur (1).

29. Metatibia of males widest at middle and apex (0), widest at middle (1), or widest at apex (2).

30. Tarsomere 4 with spines straight (0) or recurved at their apices (1).

31. Metatarsomere 4 with enlarged medial spine (0) or without enlarged medial spine at apex (1).

32. Protarsomere 5 in males without medio-ventral tooth $(0)$ or with tooth (1).

33. Mesotarsomere 5 in males with medio-ventral tooth $(0)$ or without tooth (1).

34. Metatarsomere 5 in males with medio-ventral tooth (0) or without tooth (1).

35. Unguitractor plate with apical setae (0) or with apical and preapical setae (1).

36. Modified claw on mesotarsus in males thickened and bifurcate (Figs. 67) (0), simple (1), or with a ventral tooth (Fig. 8) (2).

37. Modified claw on metatarsus in males thickened and bifurcate (Figs. 6-7) (0), simple (1), or with a ventral tooth (Fig. 8) (2).

\section{Genitalia}

38. Paramere length greater than width (0) or subequal to width (1).

39. Parameres with apices close together (0) or widely separated (1).

40. Parameres with baso-lateral sclerite (see Jameson and Smith [2002] for illustration) undeveloped (0) or well-developed (1).

41. Parameres with baso-lateral sclerite apically undeveloped (0), projecting outward (1), or attached to paramere (2).

A. pilicollis (male), A. pilicollis (male), A. pygidialis (male), A. valdiviensis (male paratype). Third row: A. viridis (male), Brachysternus angustus (female), B. germaini (male neotype), B. marginatus (female), B. olivaceus (male). Fourth row: B. patagoniensis (male paratype). B. prasinus (female), B. prasinus (female), B. prasinus (female). B. spectabilis (female). Fifth row: B. spectabilis (male). Hylamorpha elegans (male), $H$. elegans (female), H. elegans (male), H. elegans (female). 
42. Parameres with baso-ventral sclerite (see Jameson and Smith [2002] for illustration) undeveloped (0) or developed (1).

43. Parameres with baso-ventral sclerite medially undeveloped (0), thickened (1), or not thickened (2).

44. Parameres with baso-ventral sclerite shape (see Jameson and Smith for illustration) absent (0), inverted " $V$ " (1), inverted " $U$ " (2), or inverted "Y."

45. Parameres basally with broad, medial furrow present (Figs. 12-15) (0) or absent (Figs. 16-20) (1).

Phylogenetic Methods. Initially, all characters used were unordered, of equal weight, and parsimony-informative. The character matrix is small enough to effectively do a parsimony analysis using a branch-and-bound search. This method ensures that the shortest possible trees are found. The analysis was performed in PAUP* (Swofford 2000) using the following settings: initial upper bound - compute via stepwise, keep-minimal trees only, save all optimal trees, and addition sequence-furthest. The initial branch-and-bound search found 290 shortest trees with a length of 129 , consistency index 0.574 , retention index 0.771, and rescaled consistency index 0.442 . The consistency index is a measure of homoplasy (rate of character convergence) on a scale of 0 to 1 ; the retention index is a measure of synapomorphic characters supporting monophyletic groups which is on a scale of 0 to 1 ; and the rescaled consistency index is a product of the other two indices (Maddison and Maddison 2000).

After an initial branch-and-bound search, the characters are re-weighted in PAUP* using the consistency index, maximum value (best fit), and base weight $=1$. This technique is called successive weighting (Farris 1969) and uses the results of the first analysis to reweight each character based on homoplasy. After the characters are re-weighted; a new branch-and-bound search was performed. Stability was reached after one iteration (further character reweighting yielded the same eight trees). The successive weighting did not alter the topography of the tree but provided more resolution within the genus Brachysternus and among the outgroup taxa. The successive weighting yielded eight equally parsimonious trees with a length of 80.4 , consistency index of 0.682 , retention index of 0.841 , and rescaled consistency index of 0.574 . The consistency index of 0.682 for this tree is reasonable for a matrix of this size (Meier et al. 1991). This indicates that homoplasy is not a major concern with the matrix and character weights used in the final analysis. The retention index of 0.841 for this tree is consistent with a matrix of this size and suggests that the characters in general support monophyletic clades. The trees were evaluated using a bootstrap method with full heuristic search with 1,000 replicates. A strict consensus tree based on the eight equally parsimonious, phylogenetic trees with the bootstrap support values for the clades is shown in Figure. 2.

The results of the phylogenetic analyses demonstrate, with high support, that the genera Aulacopalpus (97\% bootstrap support), Brachysternus (100\% bootstrap support), and Hylamorpha and the subtribe Brachysternina (100\% bootstrap support) are monophyletic clades. Character states that are synapomorphic within the Brachysternina clade include head densely punctate (character 8); elytral striae distinct (character 18); elytron border membranous (character 19); pygidium bearing setae (character 22); females with apex of terminal abdominal sternite flattened or emarginate (character 27); protibia without inner, apical spur (character 28); and paramere length approximately equal to width (character 38). 


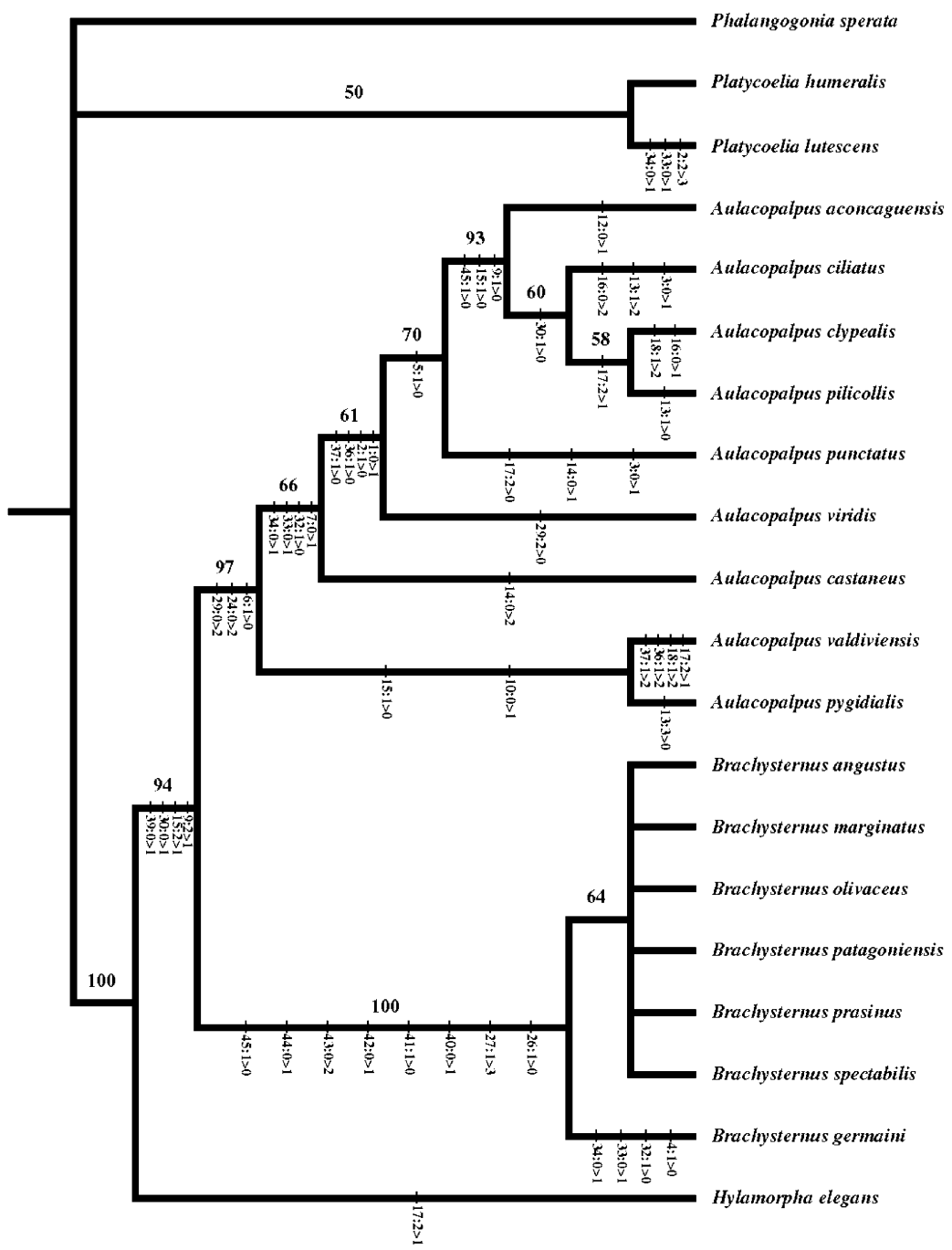

Fig. 2. Strict consensus tree of the Brachysternina based on eight equally parsimonious trees with bootstrap support values for the clades. Unambiguous character state changes are indicated on branches.

The clade that comprises the genus Aulacopalpus is highly resolved (97\% bootstrap support). Character states defining the Aulacopalpus clade include clypeal apex rounded (character 6); pygidial setae hair-like (character 22); metathoracic process absent (character 24); and metatibia of males widest at apex (character 29). The A. valdiviensis Smith + A. pygidialis Ohaus clade is most basal within the genus. The main synapomorphic characters for this clade are the large eyes (interocular width less than two eye widths, character 10) and tarsomere five with a ventromedial tooth (characters 32, 33, and 34). Large 
eyes are unique to these two species, and the ventromedial tooth on tarsomere five is a primitive character state in the genus because it is shared with the sister group, Brachysternus. The clade apical to A. valdiviensis + A. pygidialis consists of the seven remaining species of Aulacopalpus. All species share the loss of the ventromedial tooth on tarsomere five. The basal species within this clade is $A$. castaneus (Laporte). The remaining six species (A. viridis [GuérinMéneville], A. punctatus [Fairmaire and Germain] A. aconcaguensis Smith, $A$. ciliatus [Solier], A. clypealis Ohaus, and A. pilicollis [Fairmaire]) share the great reduction of mouthparts (mandibles, maxilla, and mentum; characters 1 , 2 , and 5 respectively), the males have all claws with one claw thickened and bifurcate (character 36 and 37), and the females have all claws with a ventral tooth on the modified claw.

The reconstructed phylogeny demonstrates excellent support for the Brachysternus clade (100\% bootstrap support). The Brachysternus clade shares the character states of abdominal sternites with thickened, hair-like or scalelike setae (character 25); terminal spiracle with longitudinal groove on ventral side (character 26); apex of female terminal abdominal sternite emarginate (character 27); parameres with baso-lateral sclerite well developed (character 40); and parameres with baso-ventral sclerite well developed (character 42). Within this clade, B. germaini (Ohaus) (transferred from Aulacopalpus to Brachysternus by Jameson and Smith 2002) is the basal taxon and possesses some characters reversals relative to other species within the clade (characters 4, 32, 33, 34, 36, and 37). The remaining six species of Brachysternus are poorly resolved. This is likely due to the extreme interspecific and intraspecific variation of characters in this genus (particularly $B$. olivaceus Philippi and Philippi, B. prasinus Guérin-Méneville, and B. spectabilis Erichson) that makes determination of relationships difficult.

Aulacopalpus and Brachysternus are sister taxa in the Brachysternina clade and the Aulacopalpus + Brachysternus clade is the sister group to the monotypic genus Hylamorpha. The species Hylamorpha elegans (Burmeister) has autapomorphic characters that distinguishes it from the rest of the Brachysternina, but these characters are not parsimony-informative and are not included in the phylogenetic analysis. These characters include the multisetose unguitractor plate and elytron bearing scale-like setae.

\section{Biogeography and Distribution of the Brachysternina}

Species of Brachysternina occur from Central Chile to Tierra del Fuego (Map 4) in the Central Chilean and Subantarctic subregions of the Andean biogeographical region (Morrone 1999). The highest diversity of the group occurs in Central Chile. The Central Chilean biogeographical subregion is remarkable for its high percentage of endemic taxa. Morrone et al. (1997) conducted a biogeographical analysis of Central Chile and concluded that this region was most closely related to the Subantarctic subregion. They divided the Central Chilean subregion into areas of endemism and found that southern areas of endemism within Central Chile (Curicó and Nuble) had more affinities with the Subantarctic subregion than with the northern areas of endemism (Coquimbo and Santiago). This pattern is not evident in the Brachysternina reconstructed phylogeny (see Fig. 2) perhaps due to the wide distribution of several species over several areas of endemism. It is interesting to note that the basal species in the genus Aulacopalpus are mainly found in the southern Central Chilean subregion areas of endemism (including A. pygidialis, A. val- 
diviensis, and A. punctatus). The species of Brachysternina found in the Subantarctic subregion are generally more derived species in the reconstructed phylogeny (Brachysternus patagoniensis Jameson and Smith and A. pilicollis). Taxa closely related to Brachysternina occur in montane Latin America and Australia. Neotropical Anoplognathini are generally restricted to cool temperate and montane climates and so climate seems to be an important factor influencing distribution.

The vegetational zones in the Central Chile and Subantarctic subregions are mainly mixed Nothofagus forest (Nothofagaceae), coastal Nothofagus rainforests, moorland, and tundra. Based on my research, the most likely mechanism that explains the current distribution of Anoplognathini may be similar to that described for Nothofagus species, a genus of trees that occurs in southern South America, Australia, New Zealand, and Papua New Guinea. It was hypothesized that Nothofagus originated in southern South America or Australia during the late Cretaceous (see Hill and Dettmann 1996). The phylogeny of the genus Nothofagus (Linder and Crisp 1995, Swenson et al. 2001) suggests that at least three separate, common ancestors of the modern species dispersed between South America and Australia (a pattern also observed in staphylinid beetles by Thayer [1985]). Dispersal probably occurred through Antarctica during the late Cretaceous and early Tertiary (because fossil pollen occurs in Antarctica and is absent from the northern continents [Hill and Dettmann 1996]). Nothofagus is not the only taxon with a southern hemispheric geographical distribution. This pattern has been documented for hundreds of taxa. Howden (1981) gave an overview of the Coleoptera with southern hemispheric distributions including many Scarabaeoidea taxa.

The radiation and diversification of the mainly phytophagous "pleurostict" clade of Scarabaeidae occurred as a result of the radiation and diversification of angiosperms as the dominant life form in most terrestrial habitats (Scholtz and Chown 1995). The pleurostict clade of Scarabaeidae includes the subfamilies Melolonthinae, Rutelinae, Dynastinae, Cetoniinae (including Trichiini and Valgini) according to the phylogenetic analyses of Howden (1982), Scholtz and Chown (1995), and Browne and Scholtz (1998, 1999). The oldest recorded pleurostict scarab fossil is from Eocene coal deposits of Germany (Browne and Scholtz [1999]). But fossil records only indicate a MINIMUM age. Increasingly, evidence (based on phylogenetic reconstructions and fossils plus biogeographical information) suggests that the age and diversification of lineages of phytophagous Coleoptera (in the superfamilies Chrysomeloidea and Cuculionoidea) firmly correspond with the late Cretaceous angiosperm plant radiation (Farrell 1998; Wilf et al. 2000). These groups arose before the angiosperm radiation and were in a position to exploit and flourish with this burgeoning resource from the beginning of angiosperm evolution. I predict that similar evidence will be found for the Scarabaeoidea that pushes the rise of the pleurostict scarab clade back into the Cretaceous (along with their Scarabaeinae + Aphodiinae sister clade). Thus, the radiation of the clade took place in concordance with late Cretaceous angiosperm radiation (as opposed to after the Cretaceous as hypothesized by Scholtz and Chown [1995]). The southern hemispheric distributional data of groups such as Anoplognathini suggest a Cretaceous origin because they probably migrated between South America and Australia through Antarctica before the breakup of the Gondwana supercontinent (prior to the Tertiary). A northern or trans-oceanic dispersion for Anoplognathini is unlikely because there are no remnant populations of Anoplognathini in favorable habitats in the northern continents or on southern 
islands (such as the Falkland Islands off the coast of Argentina or New Zealand). Newton (1985) and Thayer (1985) presented strong evidence that some groups of Staphylinoidea (Coleoptera) with parallel distributional patterns had originated in Gondwana and diverged as that supercontinent fragmented.

The range of Brachysternina is well correlated with the range of South American Nothofagus trees (see Map 4). Several species of Brachysternina have been reported feeding on Nothofagus foliage (Veblen et al. 1996). Gentili and Gentili (1988) reported that Brachysternus prasinus and Hylamorpha elegans are both defoliators of Nothofagus trees. Carrillo and Cerda (1987) also reported $H$. elegans as a Nothofagus defoliator (also see comments in Ratcliffe and Ocampo [2002]). The center of diversity (for Brachysternina and Nothofagus species) is in the same Central Chilean biogeographical subregion. I hypothesize that Brachysternina distribution is influenced by the Nothofagus host plant distribution. Anoplognathini probably dispersed across Antarctica as part of the Nothofagus forest ecosystems that were known to occur on that continent until the early Tertiary (Markgraf et al. 1996; Swenson et al. 2001). As the southern continents drifted apart in the Tertiary the Neotropical and Australian Anoplognathini probably became isolated.

After the ancestral Brachysternina was isolated from their Australian relatives by the breakup of Gondwana, they further diversified into the extant species. Lineages of Brachysternina likely speciated when uplift and glaciation isolated populations from one another. In addition to the high Andes mountains, Central Chile has a low coastal range of mountains. A central valley separates the Andes and Coastal ranges. During the Pleistocene the region south of latitude $43^{\circ} \mathrm{S}$ in South America was heavily glaciated from the western coast across the Andes to the eastern foothills (Mercer 1976; Clapperton 1993; Markgraf et al. 1996). During the height of glaciation periods Nothofagus and Brachysternina habitats were greatly reduced and isolated into ice-free areas. This forced populations into refugia to the west (along the coast) and to the east of the Andes, effectively isolating populations on either side of the high Andes. This led to the divergence of taxa. During the current interglacial period, populations have expanded and many have become sympatric.

\section{Key to the Neotropical Genera of Anoplognathini}

1 Elytral margin with clear, membranous border (best seen at apex of elytra). Central Chile and Argentina to Tierra del Fuego (Brachysternina) _..-_- 2

1' Elytral margin without clear membranous border. Central México to northern Argentina

2 Unguitractor plate with 3 or more setae. Elytron bearing white, scale-like setae (sometimes absent due to abrasion). Claws simple. Tarsomere 5 with ventromedial tooth (similar to Fig. 7) -.__ Hylamorpha Arrow

2' Unguitractor plate with 2 setae. Elytron glabrous or bearing white to orange, hair-like, slender, or thick setae. Claws split, toothed, or simple (if simple, then tarsomere 5 without a tooth). Tarsomere 5 with or without ventromedial tooth

3 Dorsal color green. Pygidium and abdominal sternites with obvious thick, white setae (especially laterally at base) when viewed without magnification. Apex of female terminal abdominal sternite moderately to deeply emarginate. Male paramere with ventral and lateral sclerites

Brachysternus Guérin-Méneville

3' Dorsal color brown to olive green. Pygidium and abdominal sternites usu- 
ally with hair-like, slender, inconspicuous setae when viewed without magnification. Apex of female terminal abdominal sternite rounded. Male paramere lacking ventral and lateral sclerites

Aulacopalpus Guérin-Méneville

4 Meso- and metatibia robust, similar in thickness to femora. Tarsomeres robust, thickened, often wider than long. Dorsal color tan to reddish tan or black. Central México to Panamá. (Phalangogoniina)

Phalangogonia Burmeister

4' Meso- and metatibia slender in comparison with femora. Tarsomeres not thickened, often longer than wide. Dorsal color yellow to green or tan. Central México to northern Argentina. (Platycoeliina)

Platycoelia Dejean

\section{Clave para los géneros neotropicales de Anoplognathini}

1 Margen elitral con borde claramente membranoso (mejor visto sobre el ápice del élitro). Chile Central y Argentina hasta Tierra del Fuego (Brachysternina)

1' Margen elitral sin borde claramente membranoso. México Central hasta Norte de Argentina -

2 Empodium con 3 o más setas. Elitro con setas semejantes a escamas blancas (a veces ausentes producto de la abrasión). Uñas simples. Tarsómero 5 con diente medio intermo (Fig. 7) Hylamorpha Arrow

$2^{\prime}$ Empodium con 2 setas. Elitro glabro o con setas semejantes a pelos, gruesas o finas, blancas o naranjas. Uñas divididas, con un diente o simples (si es simple entonces el tarsómero 5 sin diente). Tarsómero 5 con o sin diente medio interno

3 Color dorsal verde. Observados sin aumento el pigidio y esternitos muestran setas blancas y gruesas (especialmante a los lados de la base). Esternito terminal de la hembra con el ápice moderadamente o profundamente emarginado. Parámeros del macho con escleritos ventrales y laterales Brachysternus Guérin-Méneville

3' Color dorsal marrón o verde oliva. Observados sin aumento el pigidio y esternitos generalmente con setas semejantes a pelos, blancas e insconspicuas. Esternito terminal de la hembra con el ápice redondeado. Parámeros del macho sin escleritos ventrales y laterales Aulacopalpus Guérin-Méneville

4 Meso- y metatibias robustas, del mismo grosor que los fémures. Tarsómeros robustos, ensanchados, usualmente mas anchos que largos. Color dorsal marrón-claro a rojizo o negro. México Central hasta Panamá. (Phalangogoniina)

Phalangogonia Burmeister

4' Meso- y metatibias delgadas si se compara con los fémures. Tarsómeros no ensanchados, generalmente mas largos que anchos. Color dorsal amarillo a verde o marrón claro. México Central hasta Argentina. (Platycoeliina) Platycoelia Dejean

\section{Revision of the Genus Aulacopalpus}

Species in the genus Aulacopalpus are round-bodied, sometimes moderately setose, olive green, brown, or tan, and 1-2 cm long (Figs. 1, 3). Species are endemic to Chile and western Argentina south to Tierra del Fuego. Aulacopalpus is the sister taxon to Brachysternus (see Jameson and Smith 2002), and Hylamorpha (see Ratcliffe and Ocampo 2002) is the sister taxon to the Au- 


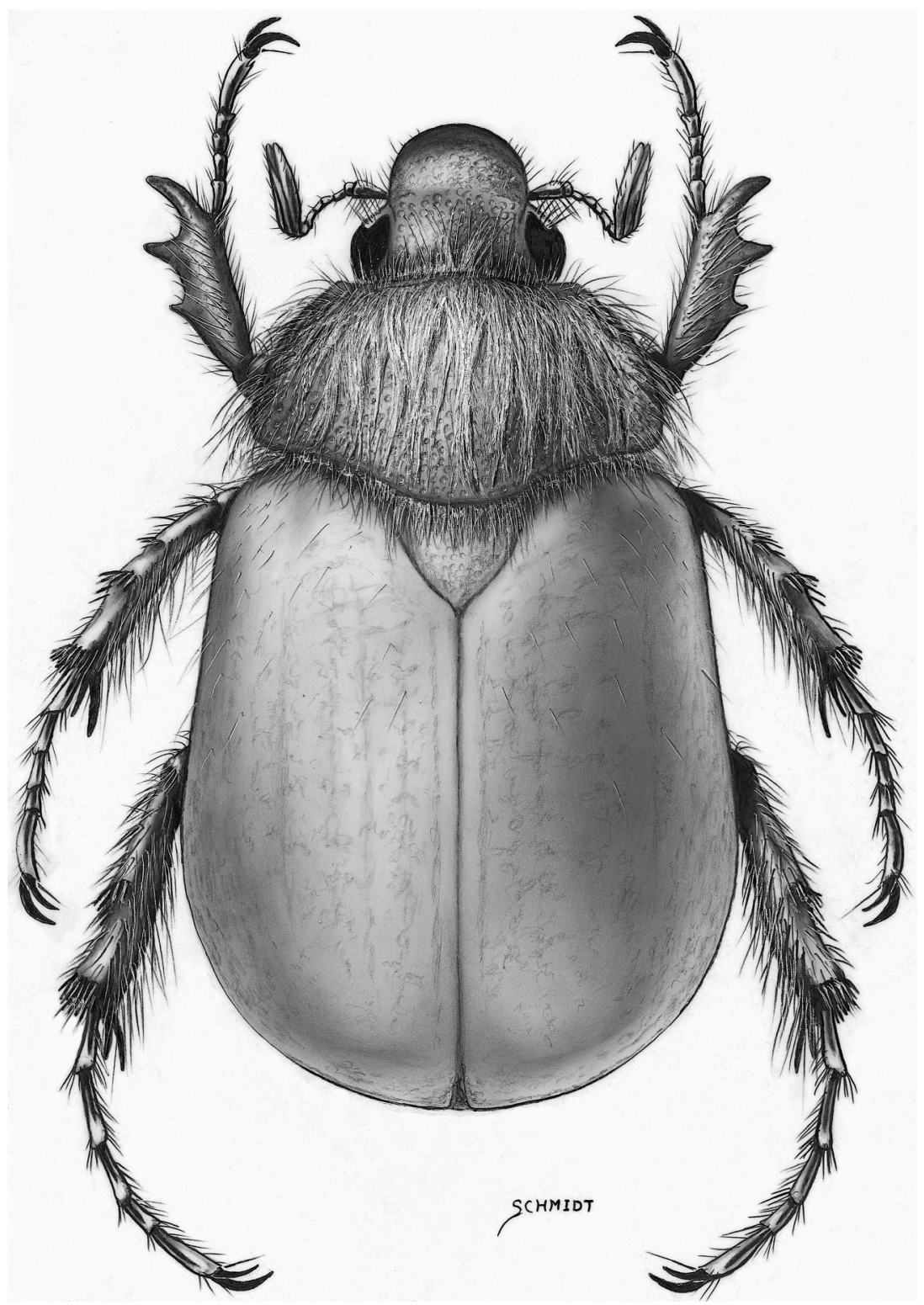

Fig. 3. Aulacopalpus pilicollis male.

lacopalpus + Brachysternus clade. These genera are endemic to Chile and Argentina, and more distantly related to Platycoelia Dejean (subtribe Platycoeliina) and Phalangogonia Burmeister (subtribe Phalangogoniina) which occur in montane regions of Central and South America. All of the previously 
mentioned genera are the New World representatives of the ruteline tribe Anoplognathini. Other genera of Anoplognathini occur in Australia and New Guinea.

Taxonomic History. The genus Aulacopalpus was originally described by Guérin-Méneville (1838a) for one species, Aulacopalpus viridis Guérin-Méneville. For the rest of the 19th century there was massive confusion over the true identity of this genus and species. Starting with Burmeister (1844) and ending with Arrow (1899), the use of Aulacopalpus often referred to the species currently named Hylamorpha elegans (Burmeister). Adding to the confusion was the fact that $A$. viridis was poorly described using specimens with incorrect locality data. The type series was labeled "Lima, Peru" but was, without doubt, from central Chile (based on the available distributional data). This was apparently a common mistake at the time, perhaps due to changes in the political borders and regional name changes of the area or confusion over where specimens where shipped to Europe as opposed to where they were collected.

A second species, Aulacopalpus castaneus (Laporte 1840) (published under his alias "le Comte de Castelnau"), was originally placed in the genus Brachysternus. The publication date of the fascicle containing the original description of $A$. castaneus may have originally been published as early as 1835, before the genus Aulacopalpus was established (see Evenhuis 1997). Laporte (1840) did not mention Aulacopalpus in his description; but instead he made comparisons with Anoplognathus Leach, an Australian genus. Burmeister (1844) muddied the waters even further with his redescription of $\mathrm{Au}$ lacopalpus viridis and description of A. elegans Burmeister (=Hylamorpha elegans) which lead to confusion between $A$. viridis and what is now the genus Hylamorpha. This confusion led Curtis (1845) to erect a new genus, Tribostethes, for the species A. castaneus and led Solier (1851) to erect Bembegeneius for his new species, $B$. fulvescens (=A. castaneus). Solier (1851) also described T. ciliatus Solier (=A. ciliatus). Fairmaire and Germain (1860) added one more species, T. punctatus Fairmaire and Germain (=A. punctatus). Philippi (1861) then described Amblyterus variabilis Philippi (=Aulacopalpus punctatus [Fairmaire and Germain]) (Amblyterus Macleay is an Australian genus). Philippi and Philippi (1864) added two more species that were both later synonymized, $T$. virens $(=A$. viridis $)$ and $T$. cupreus $(=A$. castaneus $)$.

Harold (1869a) erected the genus Sulcipalpus as a replacement name for Aulacopalpus, later stating that the replacement name was necessary because Aulacopalpus was nomenclaturally an "improper hybrid" (Harold 1869b). The current rules of nomenclature recognize such names as available, and therefore Sulcipalpus is an unjustified emendation and a junior objective synonym of Aulacopalpus. Machatschke (1965) later stated that Aulacopalpus elegans Burmeister is the type species for Sulcipalpus. However, this was an improper type species designation because the rules of nomenclature (International Commission on Zoological Nomenclature 1999) clearly state that the type species of a replacement generic name must be the same as the generic name it is replacing (article 67.8). Therefore, Aulacopalpus viridis Guérin-Méneville is the type species for the generic name Sulcipalpus, thus clarifying the confusion as to whether the genus Sulcipalpus was a junior synonym of Aulacopalpus or a senior synonym of Hylamorpha. Fairmaire (1883) added another species, Tribostethes pilicollis $(=A$. pilicollis). Arrow (1899) clarified the nomenclature of the group when he briefly redescribed $A$. viridis and erected the genus Hylamorpha to accommodate H. elegans (he also described two new species 
of Hylamorpha that are now synonyms of H. elegans [see Ratcliffe and Ocampo 2002]). Arrow considered Tribostethes ciliatus to be so different from the other species of Aulacopalpus and Tribostethes that he erected the genus Pseudadelphus for this species.

Germain (1905), in his review of the genus Brachysternus, included a key to the genera of "Bracquisternidos chilenos." He correctly applied the generic name Brachysternus but used Sulcipalpus instead of Hylamorpha. Germain's key also used Tribostethes, Pseudadelphus, and two new genera, Melicurus and Amblyterodes instead of the correct name: Aulacopalpus. Article 12 in the rules of nomenclature states that "to be available, every new name published before $1931 \ldots$ must be accompanied by a description or a definition of the taxon that it denotes, or by an indication" (International Commission on Zoological Nomenclature 1999). Therefore, Germain's two new generic names are available under the rules of nomenclature because he gave a description of each genus in his key to Chilean brachysternines (even though no species were placed in either genus). Germain intended to continue with a revision of the genera now considered Aulacopalpus, but this was never published. Germain (1905) and Ohaus (1905) revised the brachysternine species at the same time, apparently oblivious to one another (see Ohaus 1909 and Jameson and Smith 2002 for more details). It seems that once Ohaus's (1905) revision was published, Germain abandoned the project and sent Ohaus his material for study. Ohaus (1909) published a subsequent paper in which he synonymized some of his names and mentioned Germain's generic names (Amblyterodes and Melicurus). Based on the key couplet in Germain (1905), the generic name Amblyterodes was intended for the species Aulacopalpus viridis due to the enlarged maxillary palps of the males. This was confirmed by an A. viridis specimen in the Museum für Naturkunde in Berlin, Germany labeled "Amblyterodes palpalis P. G."' in Germain's handwriting. The specimen was undoubtedly send by Germain to Ohaus for examination. According to a catalog of the Chilean beetles then in the Chilean National Museum (Germain 1911), Amblyterodes was intended to contain one species, the never-published species "Amblyterodes palpalis." Germain (1911) stated that "Amblyterodes palpalis" was collected in Tierra del Fuego. I strongly suspect that this is an error because this is far out of the known range of Aulacopalpus viridis. In Machatschke's (1965, 1972) catalogs, he cites Aulacopalpus variabilis as the type species for Amblyterodes. However, this species does not fit the original description of the genus and was improperly designated. I designate Aulacopalpus viridis Guérin-Méneville as the type species for the genus Amblyterodes. Therefore, the type species of Amblyterodes is now fixed (under article 70.3 of the rules of nomenclature) as Aulacopalpus viridis Guérin-Méneville, misidentified as Amblyterus variabilis Philippi in the original designation by Machatschke (1965).

The generic name Melicurus was also erected by Germain (1905). The description of the genus (both claws on each leg "bifid") places it in the Melolonthinae because this state is not seen in any Rutelinae species. Germain's (1911) catalog stated that he intended Melicurus to be a monotypic genus containing the never-published species "Melicurus riverae." Unfortunately, the specimen Germain intended to designate as the type for this species was also lost from the Museo Nacional de Historia Natural in Santiago, Chile. Ohaus (1909) stated that he examined specimens of Melicurus sent to him by Germain, but that all the tarsi, antennae, and palps has been broken off during transport. Ohaus (1909) suggested that the specimens might be Aulacopalpus ciliatus but was unable to make a positive identification. Ohaus (1909) placed 
the species name "Melicurus palpalis" in synonymy with Aulacopalpus viridis, and subsequent catalogs have named " $M$. palpalis" as the type species for the genus Melicurus. However, an error was made by Ohaus (1909) because the name "M. palpalis" is unavailable because it was never published. Ohaus likely found the name on labels from the specimens sent to him by Germain. I was unable to find the "M. palpalis" specimen in the Museum für Naturkunde in Berlin, so I can only conclude that it has been lost. Until now there have been no available species placed in Melicurus and, therefore, no type species designated for the genus. I have observed that some species of Phytholaema Blanchard (Melolonthinae: Xylonychini) co-occur with Aulacopalpus species in Chile, and they resemble one another superficially. This is especially true of Phytholaema herrmanni herrmanni Germain, which superficially looks similar to Aulacopalpus ciliatus (about 10-15 mm long, dorsally dark brown in color, hair-like setae on head and pronotum) and is most likely what Germain used to describe the genus Melicurus (based on their similar gestalt and by a process of elimination). I therefore place Phytholaema herrmanni herrmanni Germain in the genus Melicurus and thereby fix that species as the type of the genus by subsequent monotypy under articles 67.2.2 and 69.3 of the rules of nomenclature (International Commission on Zoological Nomenclature 1999). This action transfers the genus Melicurus to the melolonthine tribe Xylonychini as a junior synonym of the genus Phytholaema. The following is a catalog of the use of the name Melicurus in the Rutelinae.

Genus Melicurus Germain, 1905. Melicurus Germain 1905:470 [original description in key to genera of Brachysternina]; Ohaus 1909:7 [comparison with Aulacopalpus ciliatus]; Ohaus 1918:179 [placed in synonymy with $\mathrm{Au}$ lacopalpus]; Blackwelder 1944:247 [checklist as synonym of Aulacopalpus]; Machatschke 1965:61 [catalog listing as synonym of Aulacopalpus]; Machatschke 1972:305 [catalog listing as synonym of Aulacopalpus]; Smith 2002: this paper [Phytholaema herrmanni herrmanni designated as type species, transferred to Melolonthinae: Xylonychini, placed in synonymy with Phytholaema].

The first review of species in the genus Aulacopalpus was done by Ohaus (1905) in his revision of American Anoplognathini. Ohaus clearly defined the generic limits of all Anoplognathini and stabilized the nomenclature. His classifications (with some slight modifications) are the ones still used today. Ohaus used both Aulacopalpus (including the species A. viridis, A. ciliatus, A. punctatus, A. pilicollis, A. variabilis, A. clypealis, and A. pygidialis) and Tribostethes (including the species T. castaneus and T. cupreus). He referred to Aulacopalpus as having split claws in both sexes and Tribostethes as having simple claws in both sexes. Ohaus synonymized $T$. virens $(=A$. viridis $)$ and Bembegeneius fulvescens $(=T$. castaneus); placed $A$. ciliatus, $A$. variabilis, $A$. punctatus, and $A$. pilicollis in the genus Aulacopalpus for the first time; and described A. clypealis and A. pygidialis. Five years later, Ohaus (1909) published the first key to species of the Brachysternina and described one more new species: A. fulvovirens. Until now, this was the last new species described in the subtribe Brachysternina.

Kolbe (1907) described the new melolonthine genus Aegolasia and species A. michaelseni. Martínez (1975) later recognized that Kolbe had misplaced Aegolasia in the Melolonthinae so he transferred it to the Rutelinae and synonymized Aegolasia with Aulacopalpus.

During the last 80 years there have been no major changes in the taxonomy 
of Aulacopalpus. Ohaus (1918) decided, without explanation, to lower Tribostethes to a subgenus of Aulacopalpus. Gutiérrez (1949) attempted to erect a new subgenus, "Mimotribostethes," for A. pygidialis and A. fulvovirens and defined the group as having males with only the anterior claws split and females with all simple claws. Gutiérrez (1949) did not designate a type species for the subgenus "Mimotribostethes" when he described it, and so it is an unavailable (nomen nudum) genus group name (article 13.3 of the rules of nomenclature). Machatschke (1972) elevated Tribostethes and "Mimotribostethes" from subgeneric to generic standing without explanation. Machatschke (1972) attempted to designate A. pygidialis as the type species of "Mimotribostethes." However, this action does not make "Mimotribostethes" an available name.

The following names were originally described in the genus Aulacopalpus and its synonyms but were subsequently transferred to other genera: Aulacopalpus elegans Burmeister (now Hylamorpha elegans), Aulacopalpus angustus Philippi and Philippi (now Brachysternus angustus), Tribostethes testaceus Steinheil (now a synonym of Rhizogeniates antennatus [Curtis]), Sulcipalpus subviolaceus Nonfried (now a synonym of Hylamorpha elegans), and Tribostethes germaini Ohaus (now Brachysternus germaini).

There is currently no reliable means of identification for the species of $A u$ lacopalpus. New species have been discovered with the increased number of specimens available for study since Ohaus' (1905) revision of the group. It has also become apparent by studying long series of specimens that there is great variation within some species, and some of the old names need to be synonymized. It is necessary to revise the genus in order to provide a reliable means of identification, modernize the taxonomy and classification, improve the knowledge of the species distributions, and provide a basis for further research.

\section{Methods and Materials}

Specimens. Specimens were borrowed from and deposited in 30 institutions and private collections listed below (curators listed parenthetically). A total of 736 specimens formed the basis of this revision.

$\begin{array}{ll}\text { ABTS } & \begin{array}{l}\text { Andrew B. T. Smith Collection, Lincoln, NE } \\ \text { American Museum of Natural History, New York, NY (Lee }\end{array} \\ \text { BCRC } & \begin{array}{l}\text { Herman) } \\ \text { Brett C. Ratcliffe Collection, Lincoln, NE } \\ \text { The Natural History Museum, London, England (Malcolm Ker- } \\ \text { ley) }\end{array} \\ \text { CASC } & \begin{array}{l}\text { California Academy of Sciences, San Francisco, CA (Roberta } \\ \text { Brett) }\end{array} \\ \text { CMNC } & \begin{array}{l}\text { Canadian Museum of Nature, Ottawa, ON, Canada (François } \\ \text { Génier, Bob Anderson) }\end{array} \\ \text { CMNH } & \begin{array}{l}\text { Carnegie Museum of Natural History, Pittsburgh, PA (Robert } \\ \text { Davidson) }\end{array} \\ \text { CNCI } & \begin{array}{l}\text { Canadian National Collection of Insects, Ottawa, ON, Canada } \\ \text { (Yves Bousquet) }\end{array} \\ \text { FMNH } & \begin{array}{l}\text { Field Museum of Natural History, Chicago, IL (Al Newton, } \\ \text { Philip Parrillo) }\end{array} \\ \text { Gerardo Arriagada S. Collection, Santiago, Chile } \\ \text { HAHC }\end{array}$


HNHM Zoologische Abteilung des Ungarischen Naturwissenschaftlichen Museums, Budapest, Hungary (Otto Merkl)

KSUC Kansas State University, Manhattan, KS (Ralph Charlton)

LACM Los Angeles County Museum of Natural History, Los Angeles, CA (Brian Brown)

MABC Marcos A. Beeche Collection, Santiago, Chile

MCZC Museum of Comparative Zoology, Harvard University, Cambridge, MS (Philip Perkins)

MGFT Georg Frey Collection, Naturhistorisches Museum Basel, Switzerland (Daniel Burckhardt)

MLJC Mary Liz Jameson Collection, Lincoln, NE

MLPA Departamento de Entomología, Universidad Nacional de La Plata, La Plata, Argentina (Juan Alberto Schnack)

MNHN Muséum National d'Histoire Naturelle, Paris, France (Jean Menier)

MNNC Museo Nacional de Historia Natural, Santiago, Chile (Mario Elgueta)

NHMB Entomologische Abteilung, Naturhistorisches Museum Basel, Switzerland (Daniel Burckhardt)

NMPC National Museum of Natural History, Prague, Czech Republic (Josef Jelínek)

PVGH Pedro Vidal Collection, Santiago, Chile

SEMC Snow Entomological Museum, University of Kansas, Lawrence, KS (Steve Ashe)

UMRM W. R. Enns Entomology Museum, University of Missouri, Columbia, MO (Robert Sites)

UNSM Division of Entomology, University of Nebraska State Museum, Lincoln, NE (Brett Ratcliffe)

USNM United States National Museum, Washington, D.C. (Dave Furth, Gloria House)

VMDM V. Manuel Diéguez M. Collection, Santiago, Chile

ZMHB Museum für Naturkunde der Humboldt-Universität zu Berlin, Germany (Hella Wendt)

Taxonomic Characters. The following definitions and standards were used in the generic and species descriptions.

Body length: measured from the apex of the clypeus to the apex of the elytra.

Body width: measured in the middle of the elytra.

Puncture density: dense $=$ punctures separated by less than two puncture diameters to punctures overlapping; moderate = punctures separated by 2-6 puncture diameters; sparse $=$ punctures separated by more than 6 puncture diameters.

Puncture size: large $=0.17 \mathrm{~mm}$ or larger; moderately large $=0.08-0.17$ $\mathrm{mm}$; moderate $=0.03-0.08 \mathrm{~mm}$; small $=0.03 \mathrm{~mm}$ or smaller.

Species Concept. See Jameson and Smith (2002), this issue.

Designation of Lectotypes and Neotypes. The International Code of Zoological Nomenclature (International Commission on Zoological Nomenclature 1999) requires that designations of lectotypes after 1999 must "contain an express statement of the taxonomic purpose of the designation" (74.7.3). Seven lectotypes are designated in the genus Aulacopalpus in order to preserve 

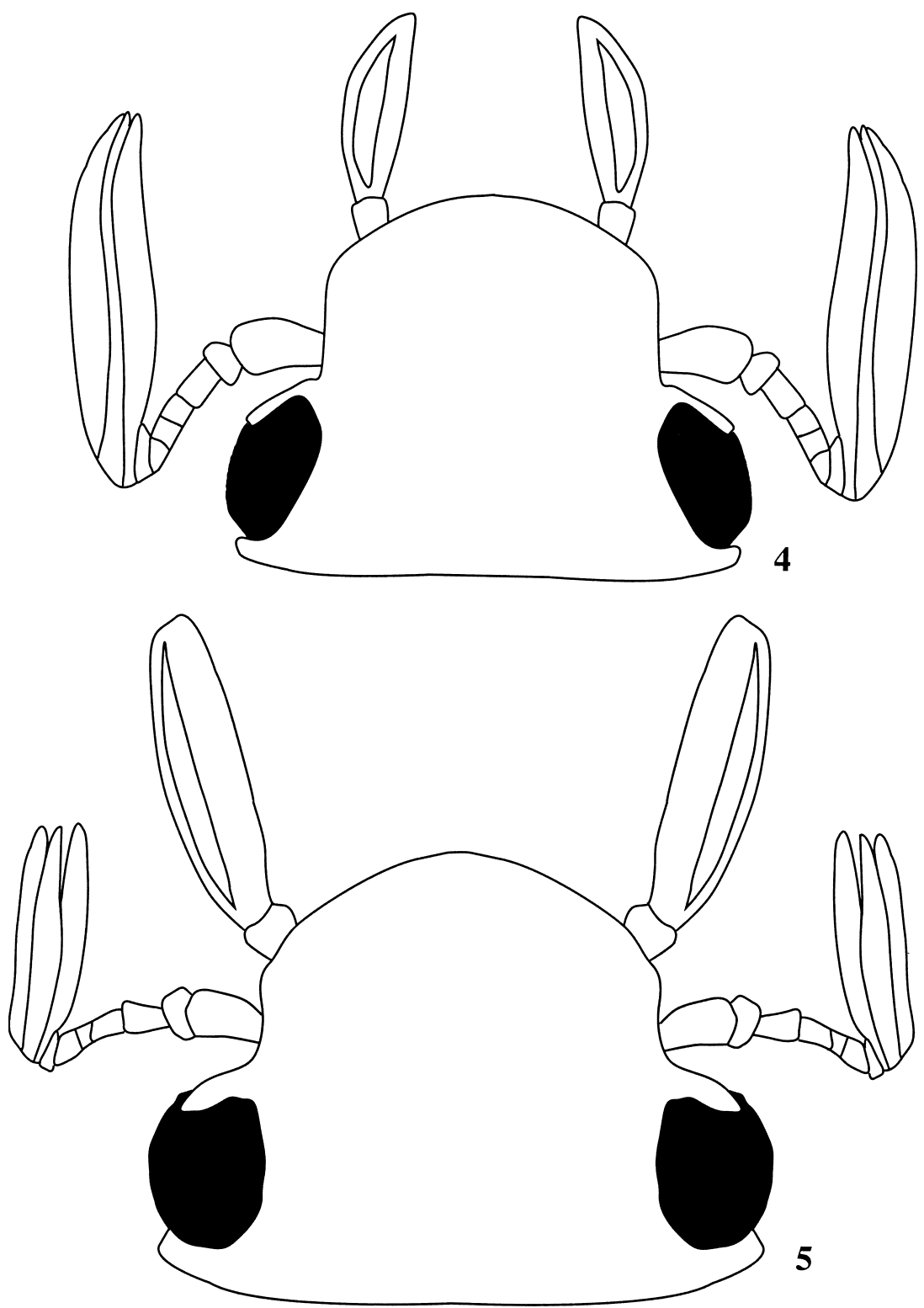

Figs. 4-5. 4) Head of male Aulacopalpus aconcaguensis. 5) Head of male Aulacopalpus viridis. 
the stability of nomenclature by selecting one specimen as the sole, namebearing type of the taxon. The lectotype specimen serves to tie the published name to an actual specimen and as a reference standard for the taxon. Lectotypes were selected for the following names: Amblyterus variabilis Philippi, Aulacopalpus clypealis Ohaus, Aulacopalpus fulvovirens Ohaus, Aulacopalpus pygidialis Ohaus, Bembegeneius fulvescens Solier, Tribostethes ciliatus Solier, and Tribostethes pilicollis Fairmaire. I feel that lectotypes are necessary for these names due to the long history of taxonomic confusion of species and names in this genus.

The International Code of Zoological Nomenclature requires that a designation of a neotype "is validly designated when there is an exceptional need and only when that need is stated expressly" (75.3). As with the lectotype designations, five neotypes are designated in the genus Aulacopalpus in order to preserve the stability of nomenclature by selecting one specimen as the sole, name-bearing type of the taxon when the original name-bearing type specimen(s) were lost or destroyed. The neotype specimen serves to tie the published name to an actual specimen and as a reference standard for the taxon. Other qualifying conditions for designating valid neotypes in section 75.3 of the code are satisfied in the discussions and descriptions of the individual species. A neotype was selected for Aegolasia michaelseni Kolbe, Aulacopalpus viridis Guérin-Méneville, Brachysternus castaneus Laporte, Tribostethes punctatus Fairmaire and Germain, and Tribostethes virens Philippi and Philippi. I feel that neotypes are necessary for these names due to the long history of taxonomic confusion of species and names in the genus. Until revisionary work is done on long neglected groups such as the Brachysternina, the taxonomy and classification are "complex zoological problems" and there is doubt surrounding the identities of all species and names.

\section{Key to the Species of Aulacopalpus}

1 Meso- and metatarsal claws simple

$1^{\prime}$ Meso- and metatarsal claws thickened and bifurcate or with ventral tooth (e.g., Figs. 6-8)

2 Tarsomere 5 with ventromedial tooth (Fig. 7)

2' Tarsomere 5 without ventromedial tooth (e.g., Figs. 6 and 8 )

3 Tarsomere 5 with ventromedial tooth (e.g., Fig. 7) A. castaneus (Laporte) A. valdiviensis Smith, n. sp.

$3^{\prime}$ Tarsomere 5 without ventromedial tooth (e.g., Figs. 6 and 8) 4

4 Dorsally bicolored with brown head, elytron; pronotum with greenish reflections. Pronotum with long, conspicuous setae in apical half. Antennal club elongated in males, longer than other segments combined, equal to or slightly shorter than head length (Fig. 4) A. aconcaguensis Smith, n. sp.

4' Dorsally with uniform or bicolored appearance. If bicolored then pronotum without conspicuous setae. Antennal club not elongated, equal to or shorter than other segments combined, much shorter than head length (similar to Fig. 5) (1-_ 5

5 Dorsal color dark or olive green 6

5' Dorsal color brown (pronotum sometimes with greenish reflections) _..._. 7

6 Maxillary palpus greatly enlarged in males, similar in size to antennal club (Fig. 5). Body length 11.7-16.3 mm. Dorsal color olive green. Pronotum 
and head not noticeably setose when viewed without magnification

A. viridis Guérin-Méneville

6' Maxillary palpus not greatly enlarged, distinctly smaller than antennal club (similar to Fig. 4). Body length 15.5-17.3 mm. Dorsal color dark green. Pronotum and head noticeably setose when viewed without magnification

A. clypealis Ohaus

7 Pronotum with strong greenish reflections, moderately punctate, sparsely setose. Elytron rugose

A. punctatus (Fairmaire and Germain)

7' Pronotum without greenish reflections (weak greenish reflections in some individuals), densely punctate, moderately to densely setose. Elytron punctate to weakly rugose

8 Dorsal color reddish-brown to dark brown. Maxillary palpus only slightly elongated, length shorter than eye diameter; widest near base. West of Andes Mountains from Coquimbo to Malleco, Chile ... A. ciliatus (Solier)

$8^{\prime}$ Dorsal color yellowish-brown to brown. Maxillary palpus noticeably elongated, length subequal to eye diameter; usually widest near middle. Generally east of Andes Mountains from Neuquén to Santa Cruz, Argentina (but also found in eastern Malleco, Chile) and the southern tip of South America (Aisén and Magallanes, Chile and Tierra del Fuego) A. pilicollis (Fairmaire)

\section{Clave par las especies de Aulacopalpus}

1 Uñas de meso- y metatarsales simples

1' Unas de meso- y metatarsales ensanchadas y bifurcadas o con un diente interno (ej. Figs. 6-8)

2 Tarsómero 5 con diente medio interno (Fig. 7)

A. pygidialis Ohaus

2' Tarsómero 5 sin diente madio interno (ej., Figs. 6 y 8)

3 Tarsómero 5 con diente medio interno (ej., Fig. 7)

A. castaneus (Laporte)

A. valdiviensis Smith, n. sp.

3' Tarsómero 5 sin diente medio interno (ej., Figs. 6 y 8 )

4 Dorsalmente bicoloreados con cabeza marrón, élitro y pronoto con reflejos verdosos. Pronoto con setas largas y conspicuas en la mitad anterior. Clava de la antena en los machos alargada, más larga que los demás segmentos juntos, igual o ligeramente más corta que el largo de la cabeza (Fig. 4) -A. aconcaguensis Smith, n. sp.

4' Dorsalmente uniformes o bicoloreados. Si bicoloreado, entonces con pronoto con setas conspicuas. Clava de la antena no alargada, igual o más corta que los demás segmentos juntos, mucho más corta que el largo de la cabeza (similar a la Fig. 5)

5 Color dorsal oscuro o verde oliva 6

5' Color dorsal marrón (pronoto a veces verdoso) 7

6 Palpo maxilar fuertemente agrandado en los machos, del mismo tamaño que la clava de la antena (Fig. 5). Largo del cuerpo 11.7-16.3 mm. Color dorsal verde oliva. Pronoto y cabeza de aspecto ligeramente setosos cuando se los observa sin aumento

A. viridis Guérin-Méneville

6' Palpo maxilar no muy agrandado en los machos, distinctivamente más pequeño que la clava de la entena (similar a la Fig. 4). Largo del cuerpo 15.5-17.3 mm. Color dorsal verde oscuro. Pronoto y cabeza notoriamente setosos cuando se los observa sin amento

A. clypealis Ohaus 
7 Pronoto con fuertes reflejos verdosos, moderadamente puncteado, dispersamente setoso. Elitro rugoso

A. punctatus (Fairmaire and Germain)

$7^{\prime}$ Pronoto sin reflejos verdosos (con reflejos verdosos en algunos ejemplares), densamente puncteado, moderada a densamente setoso. Elitro puncteado a ligeramente rugoso

8 Color dorsal marrón rojizo a marrón oscuro. Palpo maxilar sólo ligeramente alargado, más corto que el diámetro del ojo, más ancho cerca de la base. Oeste de los Andes, desde Coquimbo hasta Malleco, Chile.

A. ciliatus (Solier)

8' Color dorsal marrón amarillento a marrón. Palpo maxilar claramante alargado, largo subigual al diámetro del ojo, usualmente más ancho cerca del medio. Generalmente al Este de los Andes, desde Neuquén hasta Santa Cruz, Argentina (pero también encontrado al este en Malleco, Chile) y en el extremo Sur de Sud América (Aisén y Magallanes, Chile y Tierra del Fuego

A. pilicollis (Fairmaire)

Remarks on Identification. Additional diagnostic characters can be found in the "Diagnosis" section of each species treatment. Male genitalic characters can also be used as an identification aid (see Figs. 12-20). The parameres of A. castaneus, A. punctatus, and A. viridis are unequivocal. The parameres of Aulacopalpus pygidialis and A. valdiviensis are distinct from the other species of Aulacopalpus but virtually identical to each other. Although the parameres of A. aconcaguensis, A. ciliatus, A. clypealis, and A. pilicollis are distinct from the other species in the genus, there is great interspecific variation in the form. Other features must also be used to reliable identify these four species.

\section{Genus AULACOPALPUS Guérin-Méneville, 1838}

Aulacopalpus Guérin-Méneville 1838a:57. Type species Aulacopalpus viridis Guérin-Méneville fixed by monotypy.

Tribostethes Curtis 1845:448. Type species Brachysternus castaneus Laporte fixed by monotypy. NEW SYNONYMY.

Bembegeneius Solier 1851:84. Type species Bembegeneius fulvescens Solier fixed by monotypy. Placed in synonymy with Aulacopalpus by Ohaus (1918).

Sulcipalpus Harold 1869a:1232. Type species Aulacopalpus viridis GuérinMéneville. Sulcipalpus was proposed as a replacement name for Aulacopalpus, but the replacement name is unjustified emendation. Sulcipalpus is a junior objective synonym of Aulacopalpus and has the same type species.

Pseudadelphus Arrow 1899:369. Type species Tribostethes ciliatus Solier fixed by monotypy. Placed in synonymy with Aulacopalpus by Ohaus (1905).

Amblyterodes Germain 1905:470. Type species Aulacopalpus viridis GuérinMéneville HERE DESIGNATED (see "Taxonomic History" section). Placed in synonymy with Aulacopalpus by Ohaus (1918).

Aegolasia Kolbe 1907:112. Type species Aegolasia michaelseni Kolbe fixed by monotypy. Placed in synonymy with Aulacopalpus by Martínez (1975).

Description. Length $10.0-20.0 \mathrm{~mm}$. Width $5.5-10.8 \mathrm{~mm}$. Color: Dorsally green to brown, ventrally brown. Head: Dorsal surface punctate and setose; punctures dense, moderately large; setae long, slender, tawny to cream-colored. Frontoclypeal suture complete. Clypeal apex rounded, moderately reflexed. Labrum with apex vertically produced 


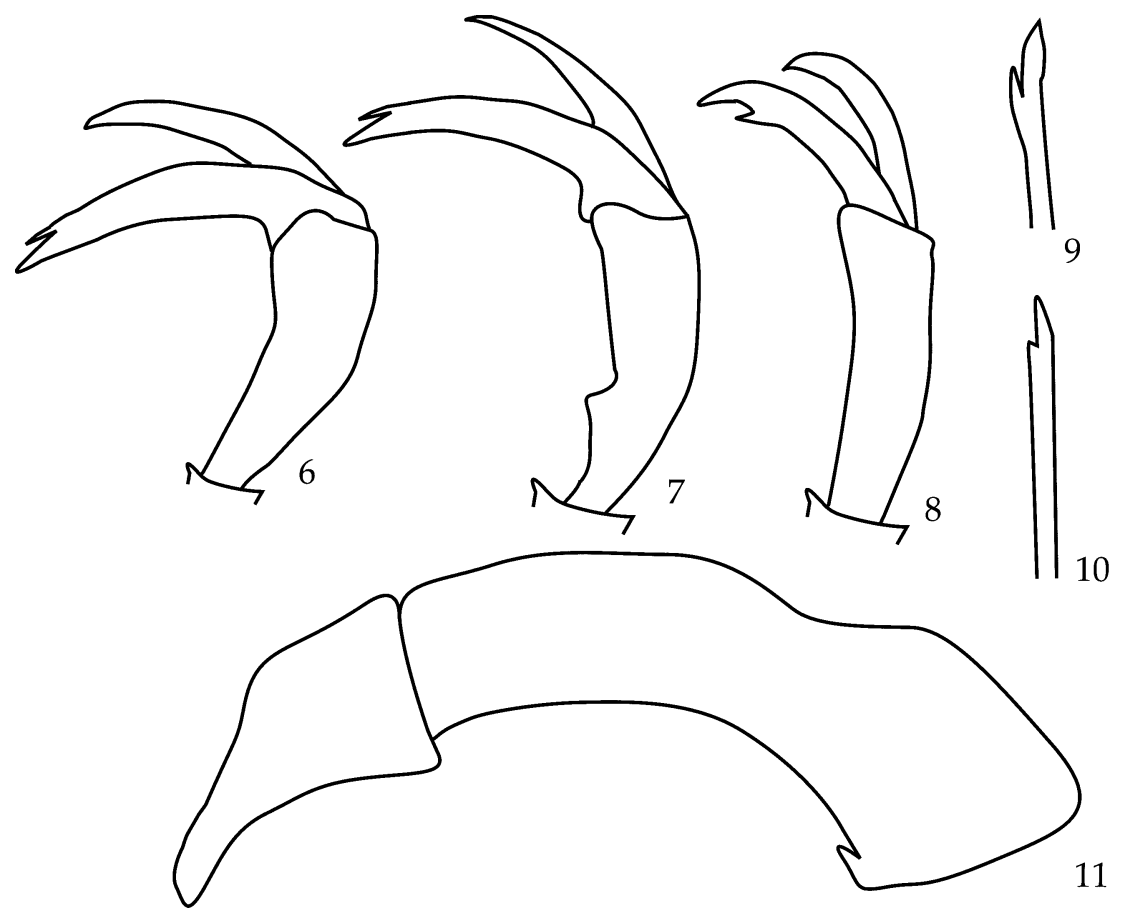

Figs. 6-11. 6) Protarsomere 5 and claw of male Aulacopalpus pilicollis, 7) Protarsomere 5 and claw of male Aulacopalpus pygidialis. 8) Protarsomere 5 and claw of female Aulacopalpus ciliatus. 9) Dorsal view of modified proclaw of male Aulacopalpus ciliatus. 10) Dorsal view of modified proclaw of male Aulacopalpus castaneus. 11) Lateral view of Aulacopalpus valdiviensis parameres and phallobase.

with respect to clypeus, moderately produced at middle, rounded or triangular. Mandibles with proximal molar lobe well developed with more than 10 black lamellae or reduced with less than 10 black lamellae. Maxillary surface moderately setose; maxilla with 35 poorly defined teeth on 2 elevated ridges or reduced with no distinguishable teeth on 1 weakly elevated ridge; maxillary palpus with terminal segment longer than basal 3 segments, with deep sulcus. Mentum with surface moderately setose, apex moderately produced or reflexed into oral cavity. Antenna 10-segmented (sometimes appearing 9segmented) with 3-segmented club. Pronotum: Form widest at middle, basomedially protuberant towards posterior. Surface moderately to densely punctate with moderately large punctures, setae usually present; setae long, slender, tawny to cream-colored. Marginal bead present laterally. Scutellum: Surface glabrous, moderately punctate with moderately large punctures. Elytron: Surface glabrous to sparsely setose; setae long, slender, tawny to cream-colored (never scale-like); longitudinal striae punctate or moderately impressed. Epipleuron rounded, marginal bead complete; row of dense setae just ventral to bead present medially, sometimes absent in apical and basal 1/5. Membranous border thickened apically. Hind Wing: Leading margin with row of setae on apical half. Vein $\mathrm{AA}_{1+2}$ about $1 / 4$ length of $\mathrm{AA}_{3+4}$. Pygidium: Surface evenly convex, sparsely to moderately punctate, setose; setae long, slender, tawny to cream-colored (never scale-like). Apex evenly rounded. Venter: Thorax densely to moderately setose; setae usually long, tawny. Prothoracic and metathoracic processes absent. Abdominal sternites moderately setose; setae moderately long, tawny, yellowish-brown, or cream-colored. Apical spiracle 
with or without supraspiracular ridge. Apical abdominal sternite of female not deeply emarginate. Legs: Coxae, trochanters, and femora moderately setose; setae long, tawny, yellowish-brown, or cream-colored. Protibia with 3 teeth in apical half. Male protarsal claws with modified claw thickened and bifurcate (sometimes weakly), male meso- and metatarsal claws with modified claw thickened and bifurcate or with all claws simple. Female tarsal claws with ventral tooth on modified claw or with all claws simple. Protarsomere 4 with or without recurved spines. Tarsomere 5 with or without ventromedial tooth. Unguitractor plate cylindrical, produced beyond apex of tarsomere 5, with 2 apical setae. Parameres: Figures. 11-20. Form symmetrical in caudal view.

Diagnosis. This genus is distinguished from all other genera of Neotropical Anoplognathini by the following combination of characters: elytron with membranous border (more pronounced at apex of elytron), metathoracic process absent, parameres with apices widely separated (not close together), unguitractor plate with 2 setae, tarsomere 5 usually without tooth (two species have the tooth), claws usually split or toothed (three species have some or all claws simple), last abdominal sternite (in females) with apex entire (not emarginate), and elytra glabrous or with setae hair-like (not thick or scale like).

Distribution (Maps 1-4). Known from central Chile and west-central Argentina south to Tierra del Fuego.

\section{Aulacopalpus aconcaguensis $\mathbf{n}$. sp.}

(Figs. 1, 4, 12, Map 1)

Types. Holotype labeled a) "CHILE: Aconcagua Cachagua 2-VIII-1974 P. Vidal \& M. Donoso," b) "FMNH986 L. Peña Coll. Acc\#17-422." Sixteen male paratypes with same data; one additional male paratype with identical locality label but without a second label. Two male paratypes labeled a) "HUAQUEN Costa Coqbo. 24, 31. Julio-1960 Coll: L. E. Pena," b) "H. \& A. HOWDEN COLLECTION ex. A. Martinez coll." Two male paratypes labeled a) "TUNQUEN Costa Valpso 6, 15 Junio-1960 Coll: L. E. Pena," b) "H. \& A. HOWDEN COLLECTION ex. A. Martinez coll." One male paratype labeled a) "ALGARROBO Costa Valpar. Julio-1957 Coll: L. E. Pena," b) "H. \& A. HOWDEN COLLECTION ex. A. Martinez coll." One male paratype labeled a) "Q. AMOLANAS Costa Coqbo. 24, 31 Julio-1960 Coll: L. E. Pena," b) “57," c) “198," d) “H. \& A. HOWDEN COLLECTION ex. A. Martinez coll." Two male paratypes labeled a) "El Totoral Sa Antonio 28-V1995 S. Rothmann," b) "COLECCION SERGIO ROTHMANN." One male paratype labeled "CHILE SN. ANTONIO Las Cruces 20-VII-1976 col. G. Arriagada." One male paratype labeled a) "CHILE SANTIAGO LAS CRUCES 20-VII-1976 Coll. G. ARRIAGADA,” b) “CHILE SN. ANTONIO Las Cruces 20-VII-1976 col. G. Arriagada.” One male paratype labeled a) “CHILE V REGION Las Cruces Julio. 1998. leg. Gerardo Arriagada," b) "COLECCIÓN Gerardo Arriagada S." One male paratype labeled "Fray Jorge Coquimbo 24-IX-1970 J. Solervicens." One male paratype labeled "Co LA CAMPANA VALPARAISO 4-9-1979 J. Solervicens." One male paratype labeled "Co Placenes Valpso. 1-VII-1968 Col. C. Vivar T."' One male paratype labeled "P. PETORCA 2 km S. Zapallar 15-II-79 A. CHUBRETOVIC." One male paratype labeled a) "FRAY JORGE Ovalle 27/VII/1987," b) "Leg. P. Vidal GH." One male paratype labeled " $182 / 1$."

Holotype and eight male paratypes at FMNH. Seven male paratypes at MNNC. Six male paratypes at UNSM. Five male paratypes at CMNC. Three male paratypes at ABTS. Two male paratypes at PVGH. One male paratype each at BCRC, GASC, MLJC. 


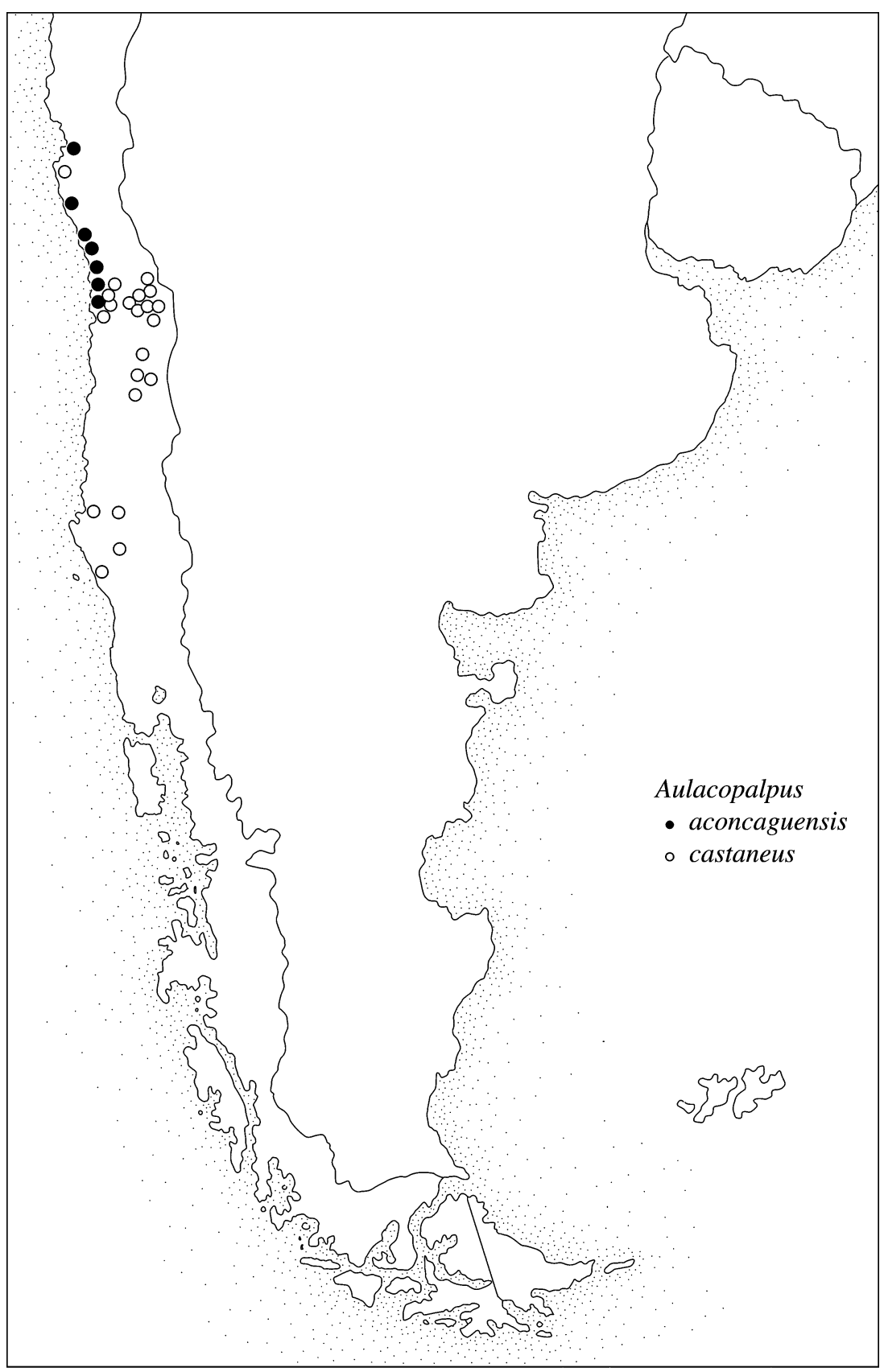

Map 1. Distribution of Aulacopalpus aconcaguensis (-) and Aulacopalpus castaneus $(\bigcirc)$. 
Holotype. Male. Length $10.9 \mathrm{~mm}$. Width $6.0 \mathrm{~mm}$. Color: head and elytron light brown, pronotum dark brown with greenish reflections. Head: Figure 4. Dorsal surface densely punctate and moderately setose; punctures moderately-sized; setae long, slender, tawny. Frontoclypeal suture weakly bisinuate. Labrum with apex vertically produced with respect to clypeus, weakly produced at middle, rounded. Maxillary palpus with terminal segment enlarged, with deep sulcus. Mentum with surface moderately setose, apex acuminate. Antenna 10-segmented (segments 5 and 6 partially fused making antenna appear 9-segmented); club elongated, flattened, longer that combined basal segments (club length approximate to head length). Pronotum: Form widest at middle, midline absent (weakly punctate in other individuals). Surface densely punctate, moderately setose; punctures moderately-sized; setae long, slender, tawny. Scutellum: Shape parabolic: 1.3 times wider than long medially. Surface densely punctate, setose; punctures moderately large; setae long, slender, tawny. Elytron: Surface glabrous. Longitudinal striae punctate; punctures moderately-sized, separated by $2-6$ puncture widths. Intervals sparsely punctate with moderately-sized punctures. Epipleuron with row of dense setae ventral to bead. Pygidium: Width 2.3 times length medially. Surface sparsely punctate, moderately setose; punctures moderately-sized; setae tawny. Venter: Thorax densely setose; setae long, tawny. Legs: Protibia with 3 subequally large teeth. Tarsal claws with modified claw slightly thickened when compared to other claw, apex bifurcate (similar to Fig. 7). Tarsomere 5 without ventromedial tooth (similar to Fig. 6). Meso- and metatibia with apical spurs slender, acute. Mesotibial apex with 17 spinules. Metatibial apex with 25 spinules. $\mathrm{Pa}$ rameres: Figure 12. Basally with broad, medial furrow.

Variation. (34 paratypes). Length 10.9-16.6 mm. Width $6.0-8.6 \mathrm{~mm}$. Color of elytron light to dark brown. The paratypes do not differ significantly from the holotype. Female unknown.

Etymology. From the latinized adjective for "Aconcaguan," referring to the region in Chile in which this species is found and the province where most of the type series was collected.

Diagnosis. This species is distinguished from all other species in the genus Aulacopalpus by the following combination of characters: antennal club elongated in males (length equal to or slightly shorter than head); pronotum green to greenish brown when viewed without magnification; elytron brown, glabrous; all tarsal claws with modified claw slightly thickened when compared to other claw and with apex bifurcate (males); tarsomere 5 without ventromedial tooth; parameres basally with broad, medial furrow.

Distribution (Map 1). Coastal Chile from Coquimbo to Santiago.

Locality Data. Based on 35 specimens examined from the CMNC, FMNH, MNNC, PVGH.

CHILE (34). ACONCAGUA (19): Cachagua, Zapallar. COQUIMBO (5): Coquimbo, Guaquén, Ovalle, Quebrada Amolanas. SANTIAGO (3): Las Cruces. VALPARAÍSO (7): Algarrobo, El Totoral, La Campana, Placeres Tunquén.

NO DATA (1).

Temporal Data. February (1), May (2), June (2), July (9), August (18), September (2).

Aulacopalpus castaneus (Laporte, 1840)

(Figs. 1, 10, 16, Map 1)

Brachysternus castaneus Laporte 1840:127. Neotype at ZMHB, labeled a)

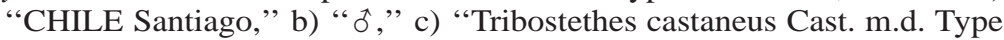
vergl. Paris 5.VII. 11.” (Ohaus's handwriting), d) "BRACHYSTERNUS CASTANEUS LAPORTE ơ DET: A.B.T.SMITH 2001 NEOTYPE," e) "Aulacopalpus CASTANEUS (LAPORTE) ô Det:A.B.T.Smith 2001." 
NEOTYPE HERE DESIGNATED. See statement of taxonomic purpose in Methods and Materials section. It is necessary to designate a neotype for $A$. castaneus because the original type has been lost. Laporte (1840) did not specify where the type was deposited. All of Laporte's types are now housed at MNHN or the Museum of Victoria in Abbotsford, Australia (MVMA). I searched for the types at the MNHN and Ken Walker (curator of entomology at the MVMA) searched for the types in the MVMA without success. I can only conclude that the types have been lost. The original type was from Chile. I selected a male neotype from Santiago, Chile that matches the original description by Laporte (1840). Laporte (1840) stated that A. castaneus is "of a copper, granulous green; (with the) pronotum and sides of the corselet with red reflections," which describes the distinct color of this species. The neotype is a specimen that was supposedly compared with the type by Friedrich Ohaus in Paris on 5 July 1911 (as indicated on the label). Based on the original description and Ohaus's label, I am confident that the neotype is virtually identical to the original type.

Bembegeneius fulvescens Solier 1851:85. Lectotype male at MNHN, labeled a) "15 43" (green, round label with handwriting underneath), b) "Bembegeneius fulvescens Sol Santiago_-_" (label sideways on pin), c) "B. fulvescens. Solier Chili. M. Gay." (green label), d) "BEMBEGENEIUS FULVESCENS SOLIER o LECTOTYPE A.B.T.SMITH 2001,” e) “ $A u$ lacopalpus CASTANEUS (LAPORTE) ô Det:A.B.T.Smith 2001.", LECTOTYPE HERE DESIGNATED. See statement of taxonomic purpose in Methods and Materials section. Solier (1851) had several specimens in the original type series. The lectotype is the only specimen in the MNHN unambiguously labeled as part of Solier's original type series. Since Solier considered Bembegeneius fulvescens and Tribostethes castaneus as different species, it is impossible to determine, with any certainty, the identity (as Solier would have determined) and type status of the unlabeled specimens in the MNHN. Therefore, the location of the paralectotypes is unknown. Placed in synonymy with A. castaneus by Ohaus (1905).

Tribostethes cupreus Philippi and Philippi 1864:321. Holotype male at MNNC, labeled a) "354," b) "Tribostethes castaneus? Carill. Julio 1864," c) "Coleccion Philippi," d) "q" (erroneous), e) "Holótipo," f) "TRIBOSTETHUS CUPREUS R. y F. PHILIPPI 1864 DET. CAMOUSSFIGHT," g) “CHILE M. N. H. N. Tipo No 2864," h) “TRIBOSTETHES CUPREUS PHILIPPI \& PHILIPPI, 1864 HOLOTYPE $0, "$ i) “Aulacopalpus CASTANEUS (LAPORTE) ơ Det:A.B.T.Smith 1999.” Philippi and Philippi (1864) stated that there was only one specimen in the type series and therefore the holotype is fixed by monotypy. They also erroneously stated that the holotype is female, but it is actually a male (with the genitalia point-mounted below the holotype on the same pin). Placed in synonymy with $A$. castaneus by Ohaus (1909).

Aulacopalpus fulvovirens Ohaus 1909:12. Lectotype male at ZMHB, labeled a) "CHILE," b) "Typus!," c) "Tribostethes fulvovirens Ohs.," d) "AULACOPALPUS FULVOVIRENS OHAUS $\hat{\sigma}$ DET: A. B. T. SMITH 2000 LECTOTYPE," e) “Zool. Mus. Berlin,” f) “Aulacopalpus CASTANEUS (LAPORTE) đo Det:A.B.T.Smith 2000." LECTOTYPE HERE DESIGNATED. See statement of taxonomic purpose in Methods and Materials section. One paralectotype male at MNNC, labeled a) 
“352,” b) “Leg. Puiques. Dec 1861," c) “Det. F. Ohaus 1909 Trib. fulvovirens ot. Ph. Ger.," d) "fulvo-virens P.G. Monogr. Brach. 2n. parte [three illegible words] 1505," e) “AULACOPALPUS FULVOVIRENS OHAUS 0 DET: A. B. T. SMITH 2000 PARALECTOTYPE,” f) “ $A u$ lacopalpus CASTANEUS (LAPORTE) ơ Det:A.B.T.Smith 2000.” One paralectotype female at ZMHB, labeled a) "o,", b) "Typus!," c) “Tribostethes fulvovirens Ohs.," d) "AULACOPALPUS FULVOVIRENS OHAUS + DET: A. B. T. SMITH 2000 PARALECTOTYPE,” e) “Zool. Mus. Berlin," f) Aulacopalpus CASTANEUS (LAPORTE) $q$ Det: A.B.T.Smith 2000." The location of other possible paralectotypes is unknown. NEW SYNONYMY.

Description. Male $(\mathrm{n}=215)$ : Length $14.9-19.2 \mathrm{~mm}$. Width $7.8-10.2 \mathrm{~mm}$. Color: dorsally brown, head and pronotum often with greenish reflections; ventrally brown. Head: Dorsal surface densely punctate, punctures moderately large. Dorsal surface with margin sparsely setose; setae long, slender, tawny to cream-colored. Frontoclypeal suture complete, weakly bisinuate. Labrum with apex vertically produced with respect to clypeus, moderately produced at middle with triangular tooth. Maxillary palpus with terminal segment longer than basal segments, with deep sulcus. Mentum with surface moderately setose, apex reflexed into oral cavity. Antenna 10-segmented, club greatly elongated (longer than combined basal segments), slightly flattened. Pronotum: Midline weakly depressed. Surface moderately punctate with moderately large punctures, sparsely setose (setae often worn off), lateral edges moderately setose; setae long, slender, tawny to cream-colored. Scutellum: Surface glabrous and moderately punctate with moderately large punctures. Shape parabolic: 1.1 times wider than long medially. Elytron: Surface glabrous, longitudinal striae punctate, moderately impressed; punctures moderately-sized, separated by 1-4 puncture widths. Interval moderately to sparsely punctate with moderately-sized punctures. Epipleuron with row of dense setae medially ventral to bead, absent in apical and basal 1/5 of length. Pygidium: Width 2.3 times length medially. Surface sparsely to moderately punctate, punctures moderately-sized, sparsely to moderately setose, setae tawny. Venter: Thorax densely setose; setae long, tawny. Legs: Protibia with 3 subequally large teeth in apical half. Protarsal claws with modified claw (Fig. 10) slightly thickened when compared to other claw; apex weakly bifurcate (often worn, appearing simple). Meso- and metatarsal claws simple (similar to Fig. 6). Tarsomere 5 without ventromedial tooth (similar to Fig. 6). Meso- and metatibia with apical spurs slender, acute. Mesotibial apex with 12-13 spinules. Metatibial apex with 19-20 spinules. Parameres: Figure 16. Basally without broad, medial furrow.

Female $(\mathrm{n}=9)$ : Length $18.0-18.8 \mathrm{~mm}$. Width $9.4-9.6 \mathrm{~mm}$. As male except in the following respects. Head: Antennal club not elongated and flattened, equal to or less than length of basal segments. Legs: Protarsal claws simple. Meso- and metatibia with apical spurs broader, blunter.

Diagnosis. This species is distinguished from all other species in the genus Aulacopalpus by the following combination of characters: size large (usually about $18 \mathrm{~mm}$ in length), antennal club elongated in males (length equal to or slightly shorter than head), pronotum greenish-brown to green, elytra brown; male protarsal claws with modified claw slightly thickened when compared to other claw and with apex weakly bifurcate (often worn and appearing simple); female protarsal claws simple; meso- and metatarsal claws simple; and tarsomere 5 without ventromedial tooth; parameres without broad, medial furrow.

Distribution (Map 1). Coquimbo to Malleco, Chile.

Locality Data. Based on 224 specimens examined from AMNH, BCRC, CASC, CMNC, CMNH, CNCI, FMNH, KSUC, MABC, MCZC, MGFT, MNHN, MNNC, PVGH, UMRM, USNM, VMDM, ZMHB.

CHILE (217). ARAUCO (23): Contulmo. COLCHAGUA (4): La Mina, La Rufina, San Fernando. CONCEPCIÓN (42): Chiguayante, Concepción. CO- 
QUIMBO (1): Socos. CURICÓ (2): Curicó, El Coigo. MALlECO (9): Angol, Renaico. NUUBLE (3): Salto del Laja. O'HIGGINS (5): Rancagua. SANTIAGO (58): Apoquindo, El Canelo, El Principal, Farellones, La Cisterna, Los Dominicos, Los Leones, Maipú, Quebrada de Macul, Renca, Santiago. TALCA (2): Molina. VALPARAÍSO (52): Algarrobo, El Quisco, El Salto, La Cruz, Limache, Olmué, Quillota, Valparaíso, Villa Alemana, Viña del Mar. NO DATA (16).

NO DATA (7).

Temporal Data. January (1), February (1), May (14), June (3), July (37), August (52), September (17), October (3) November (25), December (7).

Remarks. The variability of $A$. castaneus has resulted in confusion over the identity of this species. The main source of confusion was whether the protarsal claws of the males are simple or with modified claw slightly thickened when compared to the other claw and apex weakly bifurcate. Ohaus (1905, 1909) and Gutiérrez (1949) stated that the male protarsal claws of A. castaneus are simple, and Ohaus (1909) described a new species, A. fulvovirens, with male protarsal claws split and with a green head and pronotum but otherwise similar to A. castaneus. Based on 224 specimens, it is apparent that A. castaneus has a weakly split male protarsal claw that is often worn (or perhaps never develops in some individuals) and appears simple. I have also observed that the coloration of the head and pronotum of this species varies from brown or copper with greenish reflections to green. After careful examination of the types, and in light of the observed variation, I am synonymizing A. fulvovirens with $A$. castaneus. In fact, the "A. fulvovirens" color form is very similar to Solier's (1851) Bembegeneius fulvescens, of which Ohaus (1905) himself states "Bembegeneius fulvescens is nothing different than Tribostethes castaneus with a green head and pronotum." Solier's (1851) description and figures of Bembegeneius fulvescens are inaccurate, but I agree with Ohaus that, based on the original description and examination of the lectotype, it is a synonym of A. castaneus. I have also examined the holotype of Philippi and Philippi's (1864) Tribostethes cupreus and have determined that it fits well within my description of $A$. castaneus. I agree with Ohaus's (1909) synonymy of this species with $A$. castaneus.

\section{Aulacopalpus ciliatus (Solier, 1851)}

(Figs. 1, 8-9, 13, Map 2)

Tribostethes ciliatus Solier 1851:89. Lectotype male at MNHN, labeled a) "15 45 " (green, round label with handwriting underneath), b) "S. tago" (label sideways on pin), c) "T. ciliatus. Solier. Chili. M. Gay.," d) "TRIBOSTETHES CILIATUS SOLIER 0 LECTOTYPE A.B.T.SMITH 2001," e) “Aulacopalpus CILIATUS (SOLIER) $\delta$ Det:A.B.T.Smith 2001." LECTOTYPE HERE DESIGNATED. See statement of taxonomic purpose in Methods and Materials section. One paralectotype male at MNHN, labeled a) "15 45" (green, round label with handwriting underneath), b) "[illegible] ciliatus Sol. Santiago [illegible]" (label sideways on pin), c) "TRIBOSTETHES CILIATUS SOLIER 0 DET: A.B.T.SMITH 2001 PARALECTOTYPE," d) "Aulacopalpus CILIATUS (SOLIER) đ Det:A.B.T.Smith 2001." The location and existence of other paralectotypes is unknown.

Description. Male $(\mathrm{n}=81)$ : Length $12.2-15.3 \mathrm{~mm}$. Width $6.7-7.4 \mathrm{~mm}$. Color: dorsally reddish-brown to dark brown, sometimes with copper (pronotum) or weak greenish 


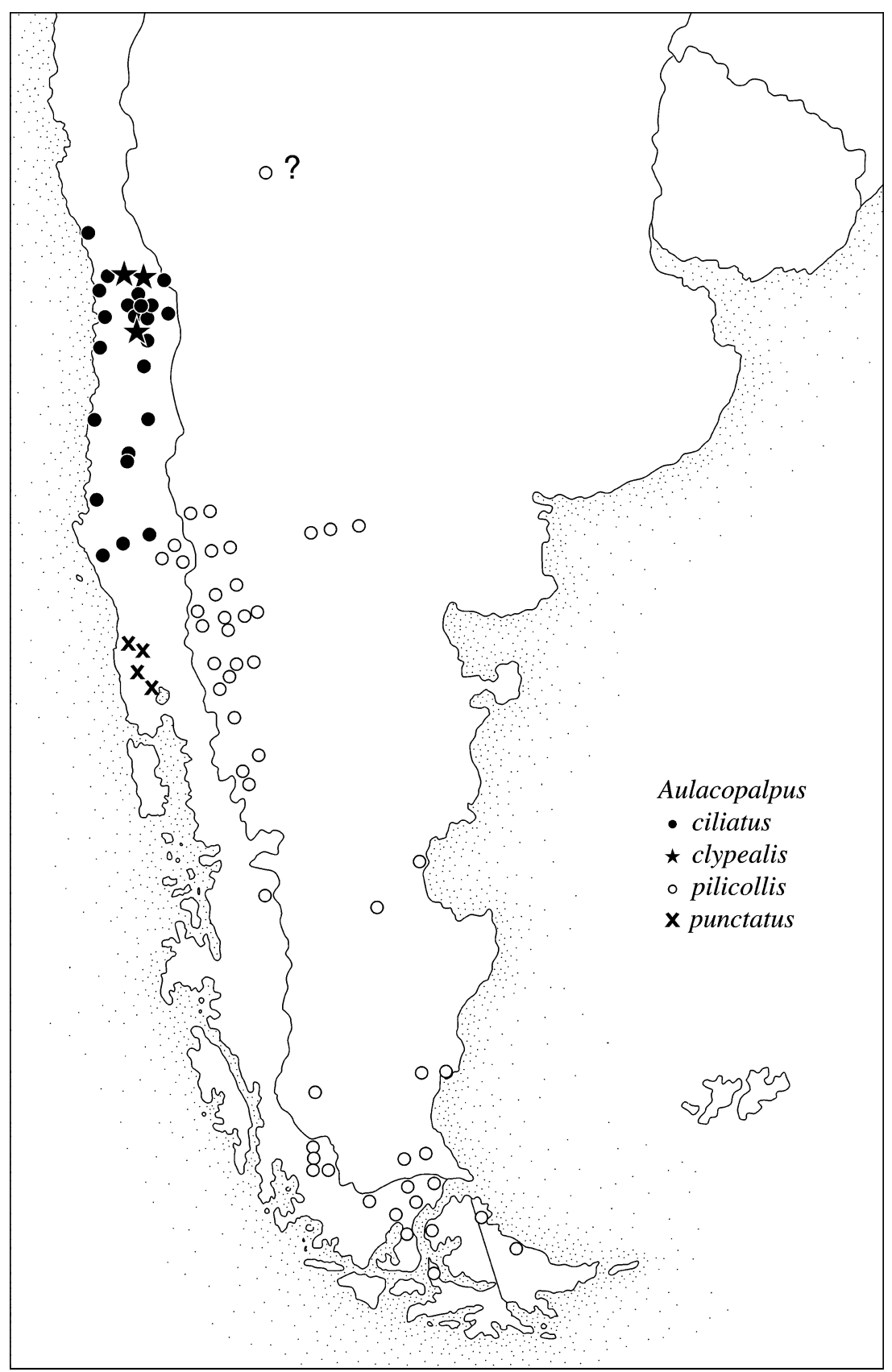

Map 2. Distribution of Aulacopalpus ciliatus (O), Aulacopalpus clypealis ( $\star$ ), Aulacopalpus pilicollis $(\bigcirc)$, and Aulacopalpus punctatus (X). 
(elytron and pronotum) reflections. Head: Dorsal surface densely punctate, moderately setose; punctures moderately large; setae long, slender, tawny to yellowish-brown. Frontoclypeal suture weakly bisinuate. Labrum with apex vertically produced with respect to clypeus, moderately produced medially with triangular tooth. Maxillary palpus with terminal segment enlarged, moderately elongate, with sulcus. Mentum with surface moderately setose, apex appearing bidentate. Antenna 10-segmented, club slightly shorter than combined basal segments. Pronotum: Midline absent. Surface moderately to densely punctate with moderately-sized punctures; moderately setose in apical half and along margins; setae long, slender, tawny to yellowish-brown. Scutellum: Surface moderately punctate, moderately setose; punctures moderately-sized; setae long, slender, tawny to yellowish-brown. Shape parabolic, 1.3 times wider than long medially. Elytron: Surface glabrous; longitudinal striae punctate, weakly impressed to not impressed; punctures moderately-sized, separated by 2-6 puncture widths. Intervals sparsely punctate with moderately-sized punctures. Epipleuron with row of thick setae present just ventral to bead. Pygidium: Width 2.0 times length medially. Surface weakly rugose; moderately setose; setae short to long, tawny to yellowish-brown. Venter: Thorax densely setose; setae long, tawny to yellowish-brown. Legs: Protibia with 3 subequally large teeth in apical half. Tarsal claws with modified claw (Fig. 9) slightly thickened when compared with other claw, apex bifurcate. Tarsomere 5 without ventromedial tooth (similar to Fig. 6). Meso- and metatibia with apical spurs slender, acute. Mesotibial apex with 15-17 spinules. Metatibial apex with 22-26 spinules. Parameres: Figure 13. Basally with broad, medial furrow.

Female $(\mathrm{n}=12)$ : Length $13.0-19.0 \mathrm{~mm}$. Width 7.1-10.1 mm. As male except in the following respects. Head: Antennal club shorter that combined basal segments. Legs: Tarsal claws (Fig. 8) with modified claw with ventral tooth, not thickened when compared with other claw, apex not bifurcate. Metatibia with apical spurs slightly broader, blunter.

Diagnosis. This species is distinguished from all other species in the genus Aulacopalpus by the following combination of characters: antennal club not elongated (length much shorter than head); pronotum brown or brown with bronze to weak green reflections; elytron usually dark brown, punctate to weakly rugose; all male tarsal claws with modified claw slightly thickened when compared with other claw and with apex bifurcate; all female tarsal claws with modified claw with a ventral tooth; tarsomere 5 without ventromedial tooth; parameres basally with broad, medial furrow.

Distribution (Map 2). Coquimbo to Malleco, Chile.

Locality Data. Based on 93 specimens examined from CASC, CMNC, CMNH, FMNH, GASC, HAHC, HNHM, MCZC, MGFT, MNHN, MNNC, NHMB, PVGH, UNSM, USNM, VMDM, ZMHB.

CHILE (88). ARAUCO (8): Contulmo. BÍO-BÍO (10): No Data. COLCHAGUA (2): San Fernando. CONCEPCIÓN (1): Concepción. COQUIMBO (2): Catarata Cavilolén, Parque Nacional Fray Jorge. LINARES (3): Parral. MALLECO (1): Angol. MAULE (1): Constitución. O’HIGGINS (5): Pencahue, Rancagua. SANTIAGO (40): Cerro Manquehue, El Canelo, El Principal, Lagunillas, Las Condes, Leyda, Lo Valdés, Maipú, Pudahuel, Quebrada de Macul, Santiago. TALCA (1): Vilches Alto. VALPARAÍSO (3): La Cruz, Quillota, Valparaíso. NO DATA (11).

NO DATA (5).

Temporal Data. January (1), April (4), May (3), June (5), July (11), August (9), September (8), October (3) November (5), December (6).

Remarks. Although the parameres (Fig. 13) are distinct in A. ciliatus there is interspecific variability in the form. This can lead to confusion between $A$. ciliatus and A. aconcaguensis, A. clypealis, and A. pilicollis when only the 
parameres are used for identification. Arias (2000) listed "pololo castaño" as the Chilean common name for this species.

Aulacopalpus clypealis Ohaus, 1905

(Figs. 1, 14, Map 2)

Aulacopalpus clypealis Ohaus 1905:137. Lectotype male at ZMHB, labeled a "Chili Kirsch," b) “Typus!," c) "A. clypealis Ohaus," d) "AULACOPALPUS CLYPEALIS OHAUS 0 LECTOTYPE A.B.T.SMITH 2001." LECTOTYPE HERE DESIGNATED. See statement of taxonomic purpose in Methods and Materials section. The existence and location of other male paralectotypes is unknown (Ohaus had no female specimens).

Description. Male $(\mathrm{n}=11)$ : Length $15.5-17.3 \mathrm{~mm}$. Width $9.0-9.8 \mathrm{~mm}$. Color: dorsally greenish-brown to shiny green, sometimes with purple reflections. Head: Dorsal surface densely punctate, punctures moderately large. Dorsal surface moderately setose; setae long, slender, tawny to yellowish-brown. Frontoclypeal suture weakly bisinuate. Labrum with apex vertically produced with respect to clypeus, moderately produced medially with triangular tooth. Maxillary palpus with terminal segment enlarged, elongate, with sulcus. Mentum with surface moderately setose, apex bidentate. Antenna 10segmented, club slightly shorter than combined basal segments. Pronotum: Midline absent. Surface moderately to densely punctate and moderately setose; punctures moderately- to moderately large-sized; setae long, slender, tawny to yellowish-brown. Scutellum: Shape parabolic: 1.4 times wider than long medially. Surface moderately punctate, moderately setose; punctures moderately-sized; setae long, slender, tawny to yellowishbrown. Elytron: Surface sparsely setose (setae often worn off); longitudinal striae punctate, weakly impressed; punctures moderately-sized, separated by 2-4 puncture widths. Intervals moderately punctate with moderately-sized punctures. Epipleuron with row of thick setae just ventral to bead. Pygidium: Width 2.0 times length medially. Surface weakly rugose, moderately setose; setae short to long, tawny to yellowish-brown. Venter: Thorax densely setose; setae long, tawny to yellowish-brown. Legs: Protibia with 3 subequally large teeth in apical half. Tarsal claws with modified claw slightly thickened when compared with other claw, apex bifurcate (similar to Fig. 7). Tarsomere 5 without ventromedial tooth (similar to Fig. 6). Meso- and metatibia with apical spurs slender, acute. Mesotibial apex with 14-16 spinules. Metatibial apex with 22-24 spinules. $\mathrm{Pa}$ rameres: Figure 14. Basally with broad, medial furrow.

Female: Unknown.

Diagnosis. This species is distinguished from all other species in the genus Aulacopalpus by the following combination of characters: antennal club not elongated (length much shorter than head); head and pronotum noticeably setose when viewed without magnification; pronotum and elytron appearing shiny green when viewed without magnification; all tarsal claws with modified claw slightly thickened when compared with other claw and with apex bifurcate (males); and tarsomere 5 without ventromedial tooth; parameres basally with broad, medial furrow.

Distribution (Map 2). Valparaíso to O’Higgins, Chile.

Locality Data. Based on 11 specimens examined from BMNH, CMNC, FMNH, PVGH, MNNC, ZMHB.

CHILE (8). O'HIGGINS (2): Parque Nacional Los Cipreses. SANTIAGO

(3): Cerro El Roble. VALPARAÍSO (1): Cerro El Roble. NO DATA (2).

NO DATA (3).

Temporal Data. October (2), November (3). 
Aulacopalpus pilicollis (Fairmaire, 1883)

(Figs. 1, 3, 6, 15, Map 2)

Tribostethes pilicollis Fairmaire 1883:491. Lectotype male at MNHN, labeled a) "Tribostethes pilicollis Fairm Magellan," b) "MUSEUM PARIS Collection Léon Fairmaire 1906," c) “TRIBOSTETHES PILICOLLIS FAIRMAIRE o LECTOTYPE DET: A. B. T. SMITH 2001,” d) “Aulacopalpus PILICOLLIS (FAIRMAIRE) ô Det:A.B.T.Smith 2001." LECTOTYPE HERE DESIGNATED. See statement of taxonomic purpose in Methods and Materials section. Fairmaire (1883) did not specify how many specimens were in the original type series. The location and existence of other paralectotypes is unknown.

Aegolasia michaelseni Kolbe 1907:112. Neotype at UNSM, labeled a) "CHILE Magallanes XI-1992 L. Peña," b) "AEGOLASIA MICHAELSENI KOLBE o DET: A.B.T.SMITH 2001 NEOTYPE," c) "Aulacopalpus PILICOLLIS (FAIRMAIRE) ô Det:A.B.T.Smith 2000.” NEOTYPE HERE DESIGNATED. See statement of taxonomic purpose in Methods and Materials section. It is necessary to designate a neotype for Aegolasia michaelseni because the original type has been lost. Kolbe (1907) did not specify where the type was deposited but it was likely deposited in the Universität von Hamburg, Zoologisches Institut und Zoologisches Museum (ZMUH) in Germany. Unfortunately, much of this collection was destroyed during World War II. I searched for the types at ZMHB (where some Kolbe types are housed) and Rudolf Abraham (curator of entomology at the ZMUH) searched for the types in the Hamburg collection without success. I can only conclude that the types have been lost. The original type was from Punta Arenas in southern Chile. I selected a male neotype from Magellanes (same general area near the Straits of Magellan) that matches the original description by Kolbe (1907). NEW SYNONYMY.

Description. Male $(\mathrm{n}=189)$ : Figure 3. Length $12.9-18.6 \mathrm{~mm}$. Width $7.5-9.8 \mathrm{~mm}$. Color: dorsally yellowish-brown to brown. Head: Dorsal surface densely punctate, moderately setose; punctures moderately large; setae long, slender, tawny to yellowish-brown. Frontoclypeal suture weakly bisinuate. Labrum with apex vertically produced with respect to clypeus, moderately produced at middle with triangular tooth. Maxillary palpus with terminal segment enlarged, elongate, with deep sulcus. Mentum with surface moderately setose, apex bidentate. Antenna 10-segmented, club slightly shorter that combined basal segments. Pronotum: Midline absent. Surface densely punctate, moderately setose; punctures moderately large; setae long, slender, tawny to yellowish-brown. Scutellum: Surface moderately punctate and moderately setose; punctures moderately-sized; setae long, slender, tawny to yellowish-brown. Shape parabolic: 1.3 times wider than long medially. Elytron: Surface moderately to sparsely setose at base, sparsely setose to glabrous toward lateral edges; setae long to short, slender, tawny (setae sometimes worn off). Longitudinal striae punctate, weakly impressed to not impressed; punctures moderately-sized, separated by 2 6 puncture widths. Intervals sparsely punctate with moderately-sized punctures. Epipleuron with row of thick setae just ventral to bead. Pygidium: Width 1.8 times length medially. Surface weakly rugose, moderately setose; setae tawny to yellowish-brown. Venter: Thorax densely setose; setae long, tawny to yellowish-brown. Legs: Protibia with 3 subequally large teeth in apical half. Tarsal claws with modified claw slightly thickened when compared with other claw, apex bifurcate (similar to Fig. 7). Tarsomere 5 without ventromedial tooth (similar to Fig. 6). Meso- and metatibia with apical spurs slender, acute. Mesotibial apex with 14-16 spinules. Metatibial apex with 22-26 spinules. Parameres: Figure 15. Basally with broad, medial furrow.

Female $(\mathrm{n}=17)$ : Length $12.9-17.9 \mathrm{~mm}$. Width $7.5-10.8 \mathrm{~mm}$. As male except in the 
following respects. Legs: Tarsal claws with modified claw with ventral tooth, not thickened when compared with other claw; apex not bifurcate (similar to Fig. 8). Metatibia with apical spurs slightly broader, blunter.

Diagnosis. This species is distinguished from all other species in the genus Aulacopalpus by the following combination of characters: antennal club not elongated (length much shorter than head); head, pronotum, and elytron yellowish-brown to brown; all male tarsal claws with modified claw slightly thickened when compared with other claw and with apex bifurcate, all female tarsal claws with modified claw with a ventral tooth, not thickened when compared with other claw; and tarsomere 5 without ventromedial tooth; parameres basally with broad, medial furrow.

Distribution (Map 2). Argentina and Chile from Malleco and Neuquén to Tierra del Fuego. Three specimens were also examined from La Rioja, Argentina.

Locality Data. Based on 206 specimens examined from BMNH, CASC, CMNC, CNCI, FMNH, LACM, MABC, MCZC, MGFT, MLJC, MLPA, MNHN, MNNC, NHMB, PVGH, SEMC, UNSM.

ARGENTINA (141). CHUBUT (20): Comodoro Rivadavia, Lago Fontana, Lepá, Trevelín, No Data. LA RIOJA (3): El Peñón, Portezuelo de Santa Rosa. NEUQUÉN (52): Collón-Curá, Confluencia, Copahue, Estancia Llamuco, Huncal, Isla Victoria, Lago Guillelmo, La Negra, La Pintada, Mallín Largo, Parque Nacional Lanín, Pico del Águila, Río Caleufú, Piedra del Águila, San Martín de Los Andes, Zapala, No Data. RÍO NEGRO (20): Cipolletti, El Bolsón, Lago Nahuel Huapí, Nirihuau, Pilcaniyeu, San Carlos de Bariloche, San Ramón, Villa Regina. SANTA CRUZ (42): Güer Aike, Lago Posadas, Las Buitreras, Las Heras, Monte Aymond (20 km E), Piedra Buena, Río La Leona, Río Santa Cruz, No Data. TIERRA DEL FUEGO (4): Puerto Baños, Punta de Arenas, Viamonte.

CHILE (61). AISÉN (2): Coyhaique. MAGALLANES (27): Bahía San Gregorio, Caleta Hops., Cerro Castillo, Isla Magdalena, Lago Sarmiento, Laguna Amarga, Laguna Figueroa, Laguna Los Palos, La Península, La Portada, Monte Aymond, Morro Chico, Pali Aike, Puerto Percy, Tierra del Fuego, No Data. MALLECO (27): Liucura, Lonquimay, Manzanar (9.2 km E), Marimenuco. NO DATA (5).

NO DATA (4).

Temporal Data. January (5), February (6), March (1), April (5), August (1), September (22), October (36) November (74), December (11).

Remarks. Although the parameres (Fig. 15) are distinct in A. pilicollis there is interspecific variability in the form. This can lead to confusion between $A$. pilicollis and $A$. aconcaguensis, A. ciliatus, and A. clypealis when only the parameres are used for identification. Fairmaire (1883) described A. pilicollis using specimens from "the coasts of Patagonia and the Magellan Strait" (likely from Punta Arenas, Chile). Kolbe (1907) later described the same species from the same locality naming it Aegolasia michaelseni, but he mistakenly placed it in the subfamily Melolonthinae. It is clear from the original description and type locality that Aegolasia michaelseni is indeed Aulacopalpus pilicollis, and I synonymize the two names. Martínez (1975) was the first to recognize that Aegolasia was not a Melolonthinae during the course of his research on the Neotropical Pachydemini (a tribe of Melolonthinae). Martínez correctly synonymized the generic name Aegolasia under Aulacopalpus but was probably not familiar enough with the group to synonymize the species name. Aulaco- 
palpus pilicollis is the most widespread and southernmost species of the genus. The three specimens from La Rioja, Argentina (collected by Antonio Martínez in January and February 1947, specimens in the CMNC) were a surprise because this is a disjunct locality at least $500 \mathrm{~km}$ north of the rest of the population (and the northern-most records of the entire subtribe Brachysternina). More collecting is necessary to determine if a) this is a relict population perhaps separated during post-Pleistocene warming, b) the populations are connected but little collecting has been done in west-central Argentina during the months of adult activity, or c) the three La Rioja specimens were somehow mislabeled and actually came from further south. Ohaus (1905) made the interesting observation, "I have received this species (A. pilicollis) in large numbers with sheep wool from Punta Arenas, which is shipped to Hamburg. The beetles probably creep into the wool bundles to hide after their period of activity in the evening and entangle their legs in the fibers, from which they cannot easily escape."

Aulacopalpus punctatus (Fairmaire and Germain, 1860)

(Figs. 1, 17, Map 2)

Tribostethes punctatus Fairmaire and Germain 1860:268. Neotype male at UNSM labeled a) "CHILE Valdivia IV-1992 L. Peña," b) "TRIBOSTETHES PUNCTATUS FAIRMAIRE \& GERMAIN $\delta$ DET: A.B.T.SMITH 2001 NEOTYPE," c) “Aulacopalpus PUNCTATUS (FAIRMAIRE \& GERMAIN) 0 Det:A.B.T.Smith 2001." NEOTYPE HERE DESIGNATED. See statement of taxonomic purpose in Methods and Materials section. It is necessary to designate a neotype for A. punctatus because the original type has been lost. Fairmaire and Germain (1860) did not specify where the type was deposited. Fairmaire's types are now housed at the MNHN and Germain's types are at the MNNC. I searched for the types at the MNHN and Mario Elgueta (curator of entomology at the MNNC) searched for the types in the MNNC without success. I can only conclude that the types have been lost. The original types were from Valdivia, Chile. I selected a male neotype from the same locality that matches the original description by Fairmaire and Germain (1860). The original description of this species is somewhat vague, but there is only one species from the vicinity of Valdivia that matches it.

Amblyterus variabilis Philippi 1861:742. Lectotype male at the NMPC, labeled a) "Amblyterus variabilis Fr. Phil. Chili," b) “TYPUS," c) "AMBLYTERUS VARIABILIS F. PHILIPPI $\hat{\sigma}$ LECTOTYPE A.B.T.SMITH 2001,” d) “Aulacopalpus PUNCTATUS (FAIRMAIRE \& GERMAIN) ơ Det:A.B.T.Smith 2001." LECTOTYPE HERE DESIGNATED. See statement of taxonomic purpose in Methods and Materials section. Two male paralectotypes at the NMPC labeled a) "TYPUS," b) "COLL. NICKERL MUS. PRAGENSE,” c) “AMBLYTERUS VARIABILIS F. PHILIPPI ${ }^{\circ}$ DET: A.B.T.SMITH 2001 PARALECTOTYPE,” d) "Aulacopalpus PUNCTATUS (FAIRMAIRE \& GERMAIN) ô Det: A.B.T.Smith 2001." One female paralectotype at the NMPC labeled a) "Amblyterus variabilis Phil. type Chili," b) "TYPUS," c) "AMBLYTERUS VARIABILIS F. PHILIPPI \& DET: A.B.T.SMITH 2001 PARALECTOTYPE," d) “Aulacopalpus PUNCTATUS (FAIRMAIRE \& GERMAIN) \& Det:A.B.T.Smith 2001.” Philippi (1861) did not specify 
how many specimens were in the type series. The location and existence of other paralectotypes is unknown. NEW SYNONYMY.

Description. Male $(\mathrm{n}=35)$ : Length $13.0-17.2 \mathrm{~mm}$. Width $6.7-8.8 \mathrm{~mm}$. Color: dorsally reddish-brown to dark brown, pronotum with greenish reflections. Head: Dorsal surface densely punctate with moderately large punctures; moderately setose adjacent to lateral margin; setae long, slender, tawny to yellowish-brown. Frontoclypeal suture weakly bisinuate. Labrum with apex vertically produced with respect to clypeus, moderately produced medially with triangular tooth. Maxillary palpus with terminal segment enlarged, moderately elongate, with sulcus. Mentum with surface moderately setose, apex appearing bidentate. Antenna 10-segmented, club slightly shorter than combined basal segments. Pronotum: Midline weak to absent. Surface moderately to densely punctate with moderately large-sized punctures; sometimes moderately setose near lateral margins; setae long, slender, tawny to yellowish-brown. Scutellum: Surface moderately punctate, punctures moderately-sized. Shape parabolic, 1.5 times wider than long medially. Elytron: Surface glabrous with rugose appearance; longitudinal striae punctate, weakly impressed to not impressed; punctures moderately-sized, separated by 2-6 puncture widths. Intervals rugose. Epipleuron with row of thick setae present just ventral to bead. Pygidium: Width 2.0 times length medially. Surface weakly rugose; moderately setose; setae short to long, tawny to yellowish-brown. Venter: Thorax densely setose; setae long, tawny to yellowish-brown. Legs: Protibia with 3 subequally large teeth in apical half. Tarsal claws with modified claw (similar to Fig. 9) slightly thickened when compared with other claw, apex bifurcate. Tarsomere 5 without ventromedial tooth (similar to Fig. 6). Meso- and metatibia with apical spurs slender, acute. Mesotibial apex with 15-17 spinules. Metatibial apex with 22-26 spinules. Parameres: Figure 17. Basally without broad, medial furrow.

Female $(\mathrm{n}=4)$ : Length $15.9-17.4 \mathrm{~mm}$. Width $8.4-9.7 \mathrm{~mm}$. As male except in the following respects. Head: Antennal club shorter that combined basal segments. Legs: Tarsal claws (similar to Fig. 8) with modified claw with ventral tooth, not thickened when compared with other claw, apex not bifurcate. Metatibia with apical spurs slightly broader, blunter.

Diagnosis. This species is distinguished from all other species in the genus Aulacopalpus by the following combination of characters: antennal club not elongated (length much shorter than head); pronotum with greenish reflections, conspicuous punctures; elytron usually dark brown with rugose appearance; all male tarsal claws with modified claw slightly thickened when compared with other claw and with apex bifurcate; all female tarsal claws with modified claw with a ventral tooth; tarsomere 5 without ventromedial tooth; parameres basally without broad, medial furrow.

Distribution (Map 2). Valdivia to Llanquihue, Chile.

Locality Data. Based on 39 specimens examined from CMNC, FMNH, MNHN, MNNC, NMPC, PVGH, UNSM, ZMHB.

CHILE (35). LLANQUIHUE (3): Frutillar, No Data. OSORNO (15): Trinquincahin, No Data. VALDIVIA (11): Isla Teja, Llancahué, Santo Domingo, Valdivia. NO DATA (6).

NO DATA (4).

Temporal Data. April (6), May (9).

Remarks. Although Fairmaire and Germain's (1860) original description and Fairmaire's (1883) later comments regarding Tribostethes punctatus are vague, they can only refer to one species. The "brown-green-bronze" color, the green pronotum with large punctures, the rugopunctate elytra, and the fact that the type locality is Valdivia leave no doubt as to the identity of A. punctatus. The character states of the lectotype of Amblyterus variabilis fall within the parameters of A. punctatus. I therefore synonymized the name Amblyterus 
variabilis under Aulacopalpus punctatus. Ohaus (1905, 1909) and Gutiérrez (1947, 1949) both misapplied the name A. punctatus to some individuals of the species A. pilicollis.

Aulacopalpus pygidialis Ohaus, 1905

(Figs. 1, 7, 19, Map 3)

Aulacopalpus pygidialis Ohaus 1905:139. Lectotype male at the ZMHB, labeled a) "CHILE," b) “Typus!," c) "A. pygidialis Ohaus," d) "AULACOPALPUS PYGIDIALIS OHAUS ơ DET: A. B. T. SMITH 2000 LECTOTYPE," e) “Zool. Mus. Berlin.” LECTOTYPE HERE DESIGNATED. See statement of taxonomic purpose in Methods and Materials section. The existence and location of other male paralectotypes is unknown (Ohaus had no female specimens).

Description. Male $(\mathrm{n}=22$ ): Length $14.6-18.5 \mathrm{~mm}$. Width 7.6-9.5 mm. Color: dorsally brown to greenish-brown, head and pronotum dark brown to brown with greenish reflections; venter brown. Head: Dorsal surface with margin sparsely setose; setae long, slender, tawny to cream-colored. Frontoclypeal suture weakly bisinuate. Clypeal surface brown, rugose. Frons green to brown with greenish reflections, densely punctate. Labrum moderately produced at middle, rounded. Maxillary palpus with terminal segment slightly shorter than basal 3 segments, with sulcus. Mentum with surface moderately setose; apex reflexed into oral cavity. Antenna 10-segmented, club greatly elongated (longer than combined basal segments), flattened. Pronotum: Midline weakly punctate. Surface moderately to densely punctate and moderately setose; punctures moderately large; setae long, slender, tawny to cream-colored. Scutellum: Shape parabolic: 1.2 times wider than long medially. Surface densely punctate, moderately setose; punctures moderately large; setae long, slender, tawny to cream-colored. Elytron: Surface glabrous; longitudinal striae punctate, weakly impressed; punctures moderately-sized, separated by 1-4 puncture widths; intervals sparsely punctate with moderately-sized punctures. Epipleuron with row of dense setae just ventral to bead present medially, absent in apical and basal 1/5. Pygidium: Width 1.6 times length medially. Surface moderately punctate, moderately setose; punctures moderate-sized; setae tawny. Venter: Thorax densely setose; setae long, tawny. Legs: Protibia with 3 subequally large teeth in apical half. Protarsal claws (Fig. 7) with modified claw slightly thickened when compared with other claw, apex weakly bifurcate (often worn, appearing simple). Meso- and metatarsal claws simple (similar to Fig. 6). Tarsomere 5 with ventromedial tooth (Fig. 7). Meso- and metatibia with apical spurs slender, acute. Mesotibial apex with 12-13 weak spinules. Metatibial apex with 18-20 weak spinules. Parameres: Figure 19. Basally without broad, medial furrow.

Female $(\mathrm{n}=1)$ : Length $16.4 \mathrm{~mm}$. Width $8.2 \mathrm{~mm}$. As male except in the following respects. Head: Antennal club not elongated and flattened, equal to or less than length of terminal segments. Legs: Tarsal claws simple. Meso- and metatibia with apical spurs broader, blunter.

Diagnosis. This species is distinguished from all other species in the genus Aulacopalpus by the following combination of characters: antennal club elongated (length equal or slightly shorter than head); head and pronotum dark brown to brown with greenish reflections; elytra brown to greenish brown; male protarsal claws with modified claw slightly thickened when compared with other claw and with apex weakly bifurcate (often worn and appearing simple); female protarsal claws simple; meso- and metatarsal claws simple in both sexes; and tarsomere 5 with ventromedial tooth; parameres basally without broad, medial furrow.

Distribution (Map 3). Chile from Concepción to Llanquihue.

Locality Data. Based on 23 specimens examined from CMNC, FMNH, MNNC, ZMHB. 


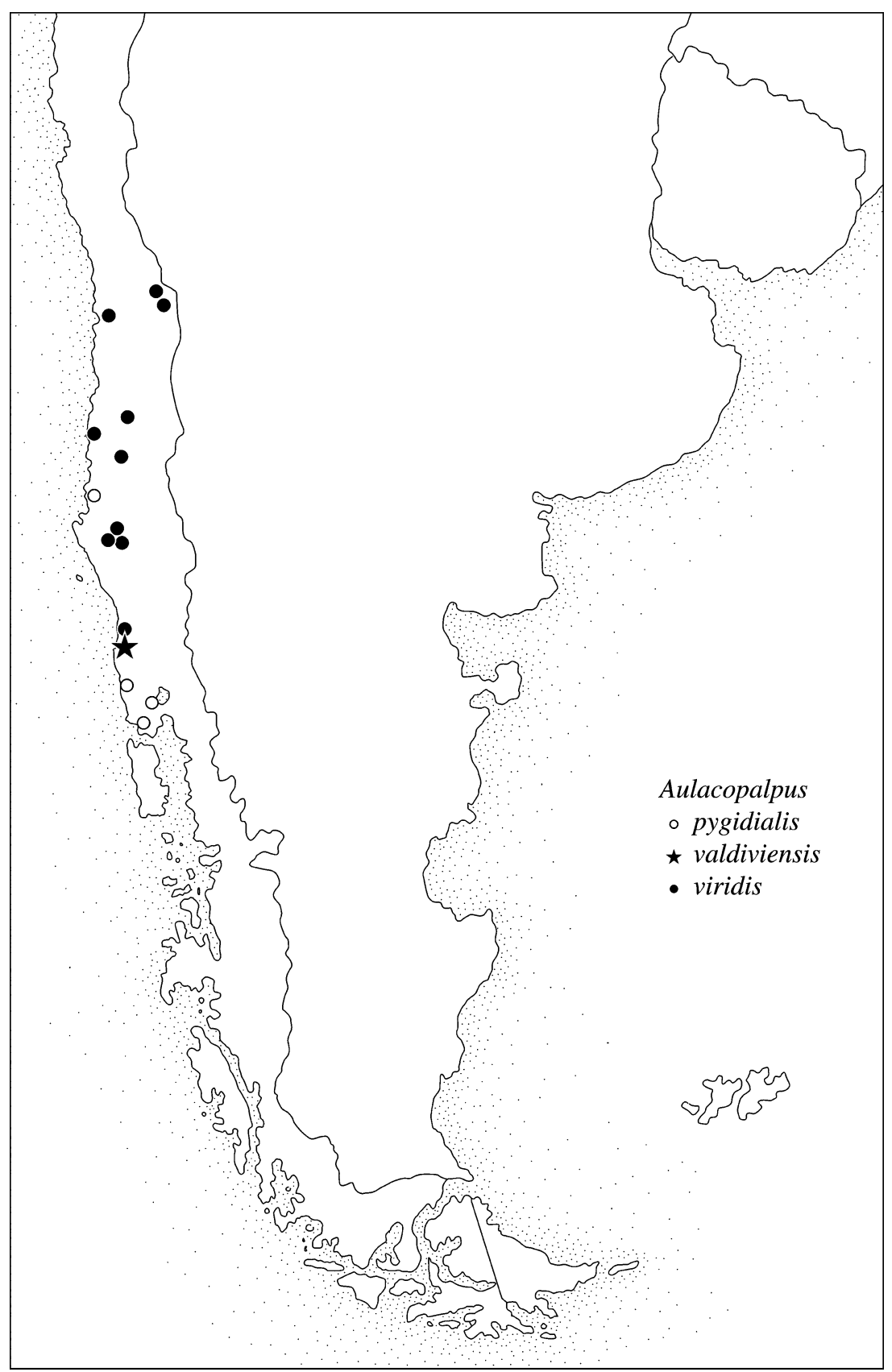

Map 3. Distribution of Aulacopalpus pygidialis $(\bigcirc)$, Aulacopalpus valdiviensis $(\star)$, and Aulacopalpus viridis (-). 


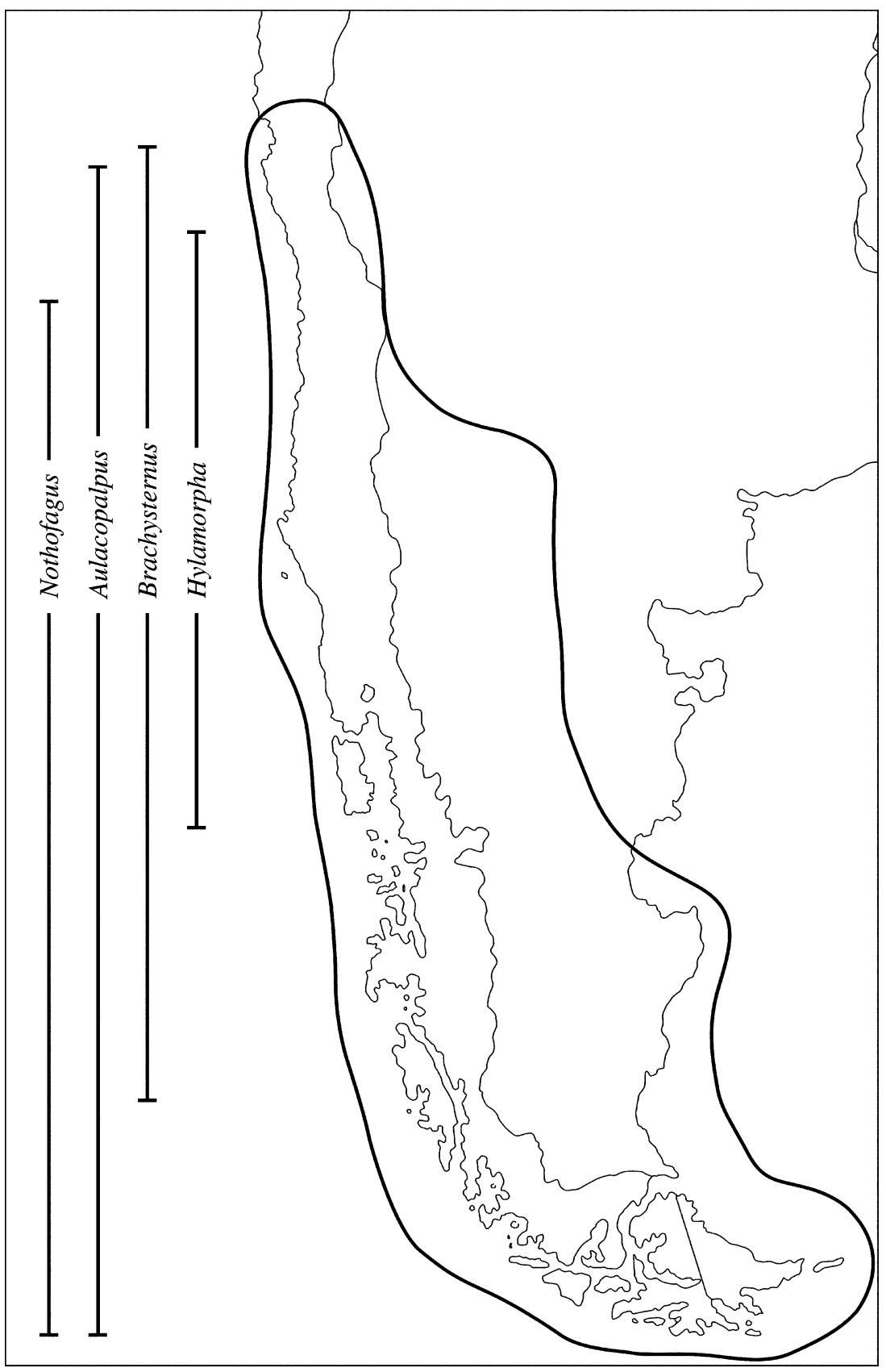

Map 4. Range of Brachysternina showing north and south limits to Nothofagus (after Veblen et al. 1996), Aulacopalpus, Brachysternus, and Hylamorpha. 
CHILE (21). CONCEPCIÓN (1): Concepción. LLANQUIHUE (8): Llanquihue, Maullín. OSORNO (11): Pucatrihue Costa. NO DATA (1).

NO DATA (2).

Temporal Data. August (11), September (3), October (1), November (5).

Remarks. Ohaus (1905) described Aulacopalpus pygidialis using only male specimens. This is the first time the female has been described.

\section{Aulacopalpus valdiviensis $\mathbf{n}$. sp.}

(Figs. 1, 11, 20, Map 3)

Types. Holotype and allotype labeled a) "Sn. Juan Corral Valdivia 30-VII1982," b) "FMNH986 L. Peña Coll. Acc\#17-422." Three male and one female paratypes with same data; one additional male paratype with same locality label but second label "Leg. P. Vidal GH." One male paratype labeled a) "Corral Valdivia Chile 9-VII-82 Leo. W. Fisher," b) "FMNH986 L. Peña Coll. Acc\#17-422." One male paratype labeled "Corral Valdivia 15 Jul. 1980 W. Fisher." One male paratype labeled a) "54068," b) "Reed," c) "Chili," d) "Fry Coll. 1905-100." One male paratype labeled a) "Reed," b) "Corral 1163," c) "Chili Corral," d) "Fry Coll. 1905-100."

Holotype, allotype and two male paratypes at FMNH. One male and one female paratype at UNSM. Two male paratypes at BMNH. One male paratype each at ABTS, MNNC, and PVGH.

Holotype. Male. Length $15.1 \mathrm{~mm}$. Width $8.6 \mathrm{~mm}$. Color: head and pronotum dorsally copper with strong greenish reflections, elytron greenish-brown; venter yellowish-brown. Head: Dorsal surface sparsely setose towards margin; setae long, slender, tawny to cream-colored. Clypeus with surface brown, rugose. Frontoclypeal suture weakly bisinuate. Frons copper colored with strong greenish reflections, densely punctate, punctures large. Labrum moderately produced at middle with triangular tooth. Maxillary palpus with terminal segment enlarged, with deep sulcus. Mentum with surface moderately setose, apex reflexed into oral cavity. Antenna 10-segmented; club elongated, flattened, longer that combined basal segments. Pronotum: Midline weakly punctate. Surface moderately to densely punctate and moderately setose; punctures moderately-sized; setae long, slender, tawny. Scutellum: Surface densely punctate, setose; punctures moderately large; setae long, slender, tawny. Shape parabolic: 1.1 times wider than long medially. Elytron: Surface glabrous, longitudinal striae punctate, weakly impressed; punctures moderately-sized, separated by 1-4 puncture widths; intervals sparsely punctate with moderately-sized punctures. Epipleuron with row of dense setae ventral to bead. Pygidium: Width 2.2 times length medially. Surface sparsely to moderately punctate and moderately setose; punctures small; setae cream-colored. Venter: Thorax densely setose; setae long, tawny. Legs: Protibia with 3 subequally large teeth. Protarsal claws with modified claw slightly thickened when compared with other claw; apex bifurcate (similar to Fig. 7). Meso- and metatarsal claws with modified claw with weak ventral tooth near apex, not thickened when compared with other claw, apex not weakly bifurcate (similar to Fig. 8). Tarsomere 5 with ventromedial tooth (similar to Fig. 7). Meso- and metatibia with apical spurs slender, acute (smaller metatibial spur greatly reduced or worn but condition is not typical). Mesotibial apex with 14 spinules. Metatibial apex with 20 spinules. Parameres: Figure 20. Basally without broad, medial furrow.

Allotype. Female. Length $15.2 \mathrm{~mm}$. Width $8.6 \mathrm{~mm}$. As male except in the following respects. Legs: Protarsal claws with modified claw with ventral tooth, not thickened when compared with other claw; apex not bifurcate.

Variation. Based upon eight male and one female paratypes. Length 14.8$17.3 \mathrm{~mm}$. Width 7.9-8.9 $\mathrm{mm}$. The paratypes do not differ significantly from the holotype.

Etymology. From the latinized adjective for "Valdivian," referring to the 

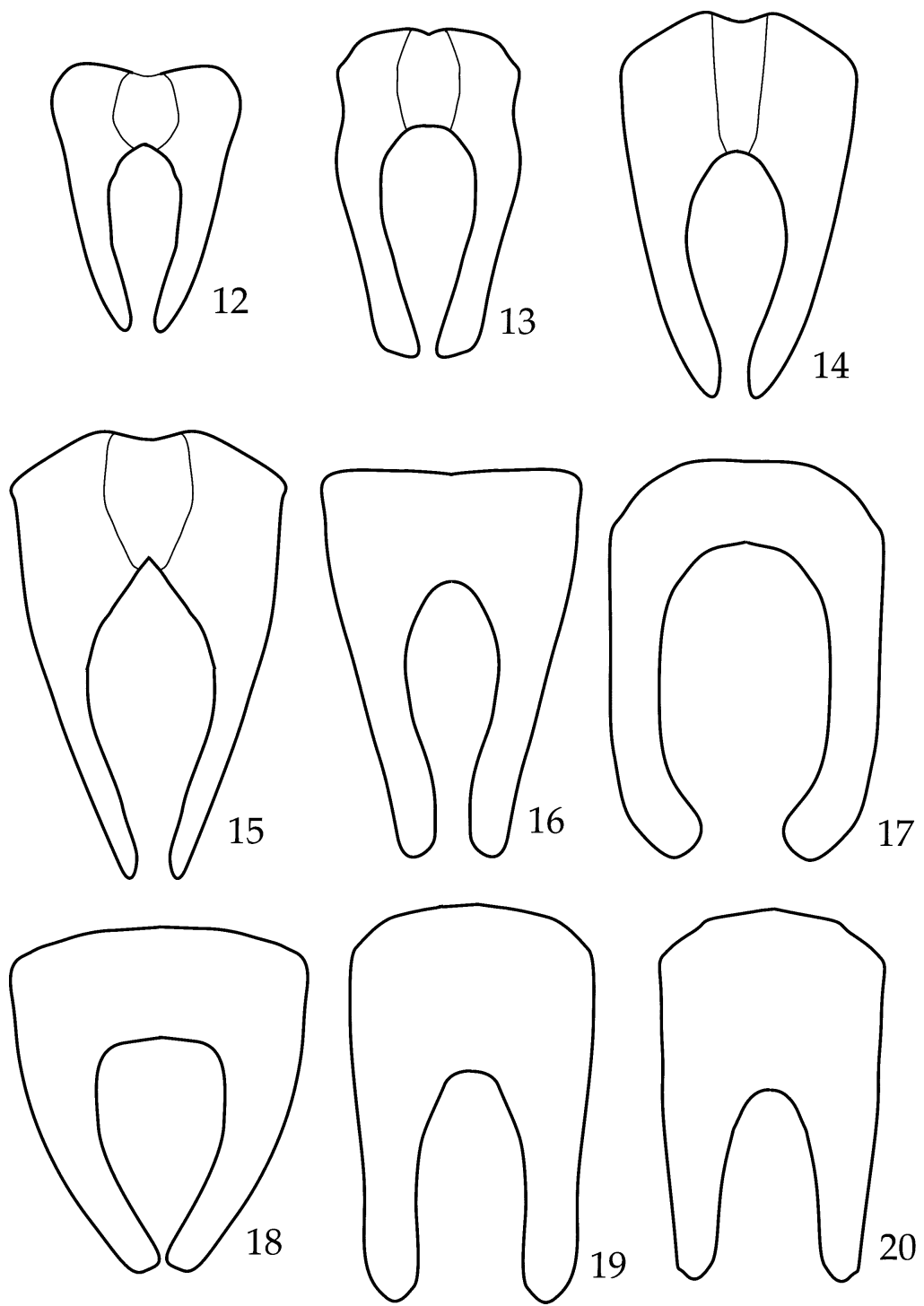

Figs. 12-20. Parameres in caudal view. 12) Aulacopalpus aconcaguensis; 13) Aulacopalpus ciliatus; 14) Aulacopalpus clypealis; 15) Aulacopalpus pilicollis; 16) Aulacopalpus castaneus; 17) Aulacopalpus punctatus; 18) Aulacopalpus viridis; 19) Aulacopalpus pygidialis, 20) Aulacopalpus valdiviensis.

region in Chile in which this species is found and the province where the entire type series was collected.

Diagnosis. This species is distinguished from all other species in the genus Aulacopalpus by the following combination of characters: antennal club elon- 
gated (length slightly shorter than head); head and pronotum dorsally copper with strong greenish reflections, elytron greenish-brown; male protarsal claws with modified claw slightly thickened when compared with other claw and with apex bifurcate; female protarsal claws with modified claw with ventral tooth, not thickened when compared with other claw, apex not bifurcate; mesoand metatarsal claws of both sexes with modified claw with weak ventral tooth near apex and not thickened when compared with other claw (unique state for males in this subtribe); and tarsomere 5 with ventromedial tooth; parameres basally without broad, medial furrow.

Distribution (Map 3). Known only from Corral, Valdivia, Chile.

Locality Data. Based on 11 specimens examined from BMNH, FMNH, MNNC, PVGH.

CHILE (11). VALDIVIA (10): Corral. NO DATA (1).

Temporal Data. July (9).

Remarks. Aulacopalpus valdiviensis is an unusual species because of the combination of claw characters of the males. This is the only species of Brachysternina with the modified protarsal claw of the male slightly thickened when compared with the other claw with the apex weakly bifurcate (normal for Aulacopalpus), but with the meso- and metatarsal claws with the modified claw with a weak ventral tooth near the apex and not bifurcate (unique in male Brachysternina). This combination of male claw characters is seen in some species of Platycoelia.

Aulacopalpus viridis Guérin-Méneville, 1838

(Figs. 1, 5, 18 Map 3)

Aulacopalpus viridis Guérin-Méneville 1838a:58. Neotype male at ZMHB, labeled a) "Chile," b) “Aulacopalpus viridis Guérin m.d. Type vergl. Paris 5.VII. 1911." (Ohaus's handwriting), c) “AULACOPALPUS VIRIDIS GUÉRIN-MÉNEVILLE ô DET: A.B.T.SMITH 2001 NEOTYPE." NEOTYPE HERE DESIGNATED. See statement of taxonomic purpose in Methods and Materials section. It is necessary to designate a neotype for $A$. viridis because the original type has been lost. Guérin-Méneville (1838a) did not specify where the type was deposited. All of Guérin-Méneville's types are now housed at MNHN. I searched for the types at the MNHN without success. I can only conclude that the types have been lost. Although the original type series were reportedly from Lima, Peru they were undoubtedly collected in central Chile. I selected a male neotype from Chile that matches the original description by Guérin-Méneville $(1838 a)$. The neotype is a specimen that was supposedly compared with the type by Friedrich Ohaus in Paris on 5 July 1911 (as indicated on the label). Based on the original description and Ohaus's label, I am confident that the neotype is virtually identical to the original type.

Tribostethes virens Philippi and Philippi 1864:320. Neotype female at the FMNH, labeled a) "TREGUALEMU N.Costa Nuble 6,9-Dic-1958 Coll: L.E.Pena," b) "FMNH986 L.PeñaColl. Acc\#17-422," c) “TRIBOSTETHES VIRENS PHILIPPI \& PHILIPPI $q$ NEOTYPE A. B. T. SMITH 2000," c) "Aulacopalpus VIRIDIS GUÉRIN-MÉNEVILLE + DET: A. B. T. SMITH 2000." NEOTYPE HERE DESIGNATED. See statement of taxonomic purpose in Methods and Materials section. It is necessary to designate a neotype for Tribostethes virens because the 
original type has been lost. All known types of Philippi and Philippi from their 1864 paper are housed in the MNNC. According to Mario Elgueta of the MNNC, the type for T. virens is not in that collection. No type was found in the NMPC where some F. Philippi specimens are housed. Philippi and Philippi did not label their types at the time (often Philippi types were labeled with only a species name or number or sometimes not at all), but many have been labeled retroactively by P. Germain and others. None of the specimens of Aulacopalpus I borrowed from the museum in Santiago fit the description given by Philippi and Philippi for $T$. virens. I can only conclude that the original type was lost from that collection. The original type was a female from San Fernando (Colchagua). The neotype was collected in the nearby province of Maule (less than $200 \mathrm{~km}$ away) and closely matches the original description of Philippi and Philippi (1864). Tribostethes virens was placed in synonymy with $A$. viridis by Ohaus (1905).

Description. Male $(\mathrm{n}=78)$ : Length $11.7-16.3 \mathrm{~mm}$. Width $6.5-8.9 \mathrm{~mm}$. Color: dorsally light to dark olive green, sometimes greenish-brown; venter brownish-yellow to yellowish-brown. Head: Figure 5. Dorsal surface densely punctate, sparsely setose, punctures moderately large; setae long, slender, tawny to cream-colored. Frontoclypeal suture complete, weakly bisinuate. Labrum moderately produced medially with triangular tooth. Maxillary palpus with terminal segment greatly enlarged, elongate (larger than antennal club), with deep sulcus. Mentum with surface moderately setose, apex reflexed into oral cavity. Antenna 9- or 10-segmented (segments 5 and 6 sometimes fused), club slightly shorter that combined basal segments. Pronotum: midline with apical half weakly depressed. Surface moderately to densely punctate with moderately-sized punctures; moderately setose in apical third and along lateral edges; setae long, slender, tawny to creamcolored. Scutellum: Shape parabolic: 1.3 times wider than long medially. Surface glabrous, moderately punctate with moderately-sized punctures. Elytron: Surface glabrous, longitudinal striae punctate, moderately impressed; punctures moderately-sized, separated by 2-6 puncture widths; interval sparsely punctate with moderately-sized punctures. Epipleuron with row of dense setae just ventral to bead medially, absent in apical and basal 1/5. Pygidium: Width 2.1 times length medially. Surface sparsely punctate, sparsely to moderately setose; punctures small; setae cream-colored. Venter: Thorax densely setose; setae long, cream-colored. Legs: Protibia with 3 subequally large teeth in apical half. Tarsal claws with modified claw slightly thickened when compared with other claw, apex bifurcate (similar to Fig. 7). Tarsomere 5 without ventromedial tooth (similar to Fig. 6). Meso- and metatibia with apical spurs slender, acute. Mesotibial apex with $12-$ 13 spinules. Metatibial apex with 17-20 spinules. Parameres: Figure 18. Basally with broad, medial furrow.

Female $(\mathrm{n}=20)$ : Length $13.3-15.3 \mathrm{~mm}$. Width $7.1-9.0 \mathrm{~mm}$. As male except in the following respects. Head: Maxillary palpus with terminal segment not enlarged or elongate (smaller than antennal club). Legs: Tarsal claws with modified claw with ventral tooth, not thickened when compared with other claw, apex not bifurcate (similar to Fig. 8). Meso- and metatibia with apical spurs broader, blunter.

Diagnosis. This species is distinguished from all other species in the genus Aulacopalpus by the following combination of characters: antennal club not elongated (length much shorter than head); male maxillary palpus with terminal segment greatly elongated (length greater than antennal club length); head, pronotum, and elytron light to dark olive green; all male tarsal claws with modified claw slightly thickened when compared with other claw and with apex bifurcate; all female tarsal claws with modified claw with ventral tooth and not thickened when compared with other claw; and tarsomere 5 without ventromedial tooth; parameres basally without broad, medial furrow. 
Distribution (Map 3). Santiago to Malleco, Chile.

Locality Data. Based on 98 specimens examined from AMNH, CASC, CMNC, CNCI, FMNH, MGFT, MNNC, UMRM, USNM.

CHILE (98). ARAUCO (23): San Alfonso (above Caramávida). LINARES (26): Linares. MALLECO (27): Angol, Collipulli, Mininco. MAULE (7): Tregualemu. NUUBLE (1): Chillán. SANTIAGO (7): El Canelo, Leyda. VALDIVIA (1): Valdivia. NO DATA (2).

Temporal Data. April (2), May (2), June (1), August (2), September (24), October (24) November (3), December (13).

Remarks. The males of $A$. viridis are easily separated from other species of Aulacopalpus due to the greatly enlarged terminal segment of the maxillary palpus. Two aspects of the original description by Guérin-Méneville (1838a) and redescriptions by Guérin-Méneville (1844) and Burmeister (1844) led to confusion over the true identity of this species: 1) it was described as having "simple, unequal tarsal claws," which is incorrect (the tarsal claws are split in males and toothed in females); 2) the type locality for the species was listed as Lima, Peru, which is also incorrect (the specimen[s] examined by GuérinMéneville were probably collected in central Chile). Solier (1851) and Blanchard (1851) both remarked that $A$. viridis was actually from Chile noting that "entomologists frequently confuse insect collections originating from the two regions (Peru and Chile) even though they are so different." The confusion probably led Philippi and Philippi to describe Tribostethes virens (a synonym of A. viridis) in 1864. Tribostethes virens was described using one female specimen that has been lost or destroyed since it is not in the Museo Nacional de Historia Natural, Santiago, Chile. Philippi and Philippi (1864) described the original type for $T$. virens as a female with a mainly greenish dorsal surface and "maxillary palpus very large with the apical segment almost 1.5 times as long as the other segments, with a deep furrow extending almost the whole length of the segment." Ohaus (1905) commented, "I determined that Tribostethes virens F. Philippi is synonymous with Aulacopalpus viridis; the description of this species fits exactly with fresh specimens of the latter species." After careful examination of the original description and many specimens, I agree with Ohaus's decision to synonymize $T$. virens with $A$. viridis, and I selected an appropriate neotype for both names.

\section{Catalog of the Subtribe Brachysternina}

Format. This catalog lists all valid (subtribal, generic, species) names in the subtribe Brachysternina. Each valid name is listed as a heading in bold text. Beneath the valid name are names used in the literature for the valid species. All names are included as they appeared in the original literature including valid names, available names (synonyms), old combinations of generic and species names, misspelled names (lapsus calami), unavailable names (nomina nuda, varieties, etc.) that have no nomenclatural status, and misapplied names (when the author misidentified a taxon or misused a name). Each name is followed by a list of references (separated by semicolons) in which that name appeared. Each reference includes the author, date, and beginning page(s) of the passage(s) mentioning the taxon as well as the nature of the content in square brackets (for example "redescription," "biology," "comment on distribution," etc.). All unavailable names are immediately followed by round brackets with a statement about their status (for example "lapsus calami," "nomen nudum," "misapplication" etc.). 


\section{Subtribe Brachysternina Burmeister, 1844}

Brachysternidae (emended to Brachysternina), Burmeister 1844:455 [original description]; Ohaus 1904b:256, 261, 277 [comparison with other Anoplognathiden, key to American Anoplognathiden]; Germain 1905:451 [redescription as a subtribe]; Ohaus 1905:124 [redescription].

Brachysternides (emended to Brachysternina), Lacordaire 1856:368, 372 [key to groups in the subtribe Anoplognathides, redescription as a "groupe"]; Arrow 1899:367 [generic amendments].

Brachysternina, Ohaus 1918:179 [catalog listing]; Blackwelder 1944:247 [checklist]; Gutiérrez 1951:113 [comparison with Platycoeliina]; Machatschke 1965:13, 60 [distribution, catalog listing, key to genera]; Machatschke 1972:304 [catalog listing]; Jameson and Smith 2002:this issue [comparison of genera]; Ratcliffe and Ocampo 2002:this issue [comparison of genera]; Smith 2002:this paper [phylogenetics, key to genera of Neotropical Anoplognathini, catalog listing].

\section{Genus Aulacopalpus Guérin-Méneville, 1838}

Aulacopalpus Guérin-Méneville 1838a:57 [original description]; Guérin-Méneville 1844:93 [redescription]; Burmeister 1844:435, 436, 458 [redescription, key to genera of Anoplognathidae]; Blanchard 1851:225 [catalog listing]; Lacordaire 1856:372, 375 [key to genera of Brachysternides, redescription]; Philippi 1861:741 [comment on distribution, morphology]; Philippi and Philippi 1864:320, 321 [comparison with Brachysternus chloris and Tribostethes ciliatus]; Harold 1869a:1231 [Sulcipalpus proposed as replacement name]; Harold 1869b:123 [comment on synonymy with Sulcipalpus]; Arrow 1899:367 [redefinition of genus]; Ohaus 1904a:63, 167 [comparison with other genera of Anoplognathiden]; Ohaus 1904b:256, 258 [comparison with other genera of Anoplognathiden]; Germain 1905:452 [comparison with other genera of Brachysternina]; Ohaus 1905: 126, 127, 140, 165 [key to genera of Brachysternina, redefinition of genus, redescription, species list]; Ohaus 1909:6, 7, 20 [key to species, species list]; Ohaus 1918:179, 181 [catalog listing, listed as synonym of Hylamorpha]; Blackwelder 1944:247 [checklist]; Gutiérrez 1949:30 [key to subgenera, list of species]; Machatschke 1965:12, 13, 60, 61, 66 [distribution, key to genera of Brachysternina, catalog listing, redescription, key to subgenera, listed as synonym of Hylamorpha]; Machatschke 1972:304, 308 [catalog listing, listed as synonym of Hylamorpha]; Martínez 1975:228 [Aegolasia placed as junior synonym]; Morón 1995:195 [comment on distribution]; Jameson and Smith 2002: this issue [comparison with Brachysternus]; Ratcliffe and Ocampo 2002:this issue [comparison with Hylamorpha]; Smith 2002:this paper [phylogenetics, key to genera of Brachysternina, revision, redescription].

Tribostethes Curtis 1845:448 [original description]; Blanchard 1851:226 [catalog listing]; Burmeister 1855:526 [comparison with Brachysternus]; Harold 1869a:1231 [catalog listing]; Arrow 1899:369 [redefinition of genus]; Ohaus 1904a:63, 167 [comparison with other genera of Anoplognathiden]; Ohaus 1904b:256, 258 [comparison with other genera of Anoplognathiden]; Germain 1905:451, 470 [comparison with other genera of Brachysternina, redefinition of genus, key to genera of Brachysternina, redescription]; Ohaus 1905:126, 127, 140,147, 149, 165 [key to genera of Brachysternina, redescription, species list]; Ohaus 1909:6, 9 [discussion of nomenclature, key to species]; Ohaus 1918: 179 [catalog listing as synonym of Aulacopalpus]; Machatschke 1965:61 [catalog listing as synonym of Aulacopalpus]; Machatschke 1972:306 [elevated from subgeneric to generic status, catalog listing]; Jameson and Smith 2002:this issue [comment on nomenclature]; Smith 2002:this paper [placed in synonymy with Aulacopalpus, listing as synonym of Aulacopalpus].

Bembegeneius Solier 1851:84 [original description]; Lacordaire 1856:374 [placed in synonymy with Brachysternus]; Germain 1905:451 [comment on description]; Ohaus 
1918:179 [placed in synonymy with Aulacopalpus, catalog listing as synonym of Aulacopalpus (Tribostethes)]; Machatschke 1965:61 [catalog listing as synonym of Aulacopalpus]; Machatschke 1972:305 [catalog listing as synonym of Aulacopalpus]; Jameson and Smith 2002:this issue [comment on nomenclature]; Smith 2002:this paper [listing as synonym of Aulacopalpus].

Tribosthetes (=Tribostethes, lapsus calami) Solier, 1851:88 [redescription].

Aulocopalpus (=Aulacopalpus, lapsus calami) Solier, 1851:90 [redescription].

Tribostethus (=Tribostethes, lapsus calami) Lacordaire 1856:372, 376 [key to genera of Brachysternides, redescription]; Philippi 1861:741 [comment on distribution]; Philippi and Philippi 1864:319, 321 [comparison with Brachysternus chloris and Aulacopalpus].

Sulcipalpus Harold 1869a:1232 [original designation]; Harold 1869b:123 [comment on emendation for Aulacopalpus]; Ohaus 1918:181 [catalog listing placed as synonym of Hylamorpha]; Blackwelder 1944:247 [checklist as synonym of Hylamorpha]; Machatschke 1965:66 [catalog listing as a synonym of Hylamorpha]; Machatschke 1972: 305 [catalog listing, placed as synonym of Aulacopalpus, catalog listing as synonym of Hylamorpha]; Jameson and Smith 2002:this issue [comment on nomenclature]; Ratcliffe and Ocampo 2002:this issue [synonym of Aulacopalpus]; Smith 2002:this paper [Aulacopalpus viridis confirmed as type species, listing as synonym of Aulacopalpus].

Pseudadelphus Arrow 1899:369 [original designation of the genus for Tribostethes ciliatus Solier]; Germain 1905:470 [key to genera of Brachysternina]; Ohaus 1905:144 [placed in synonymy with Aulacopalpus]; Ohaus 1918:179 [catalog listing as synonym of Aulacopalpus]; Blackwelder 1944:247 [checklist as synonym of Aulacopalpus]; Machatschke 1965:61 [catalog listing as synonym of Aulacopalpus]; Machatschke 1972:305 [catalog listing as synonym of Aulacopalpus]; Smith 2002:this paper [listing as synonym of Aulacopalpus].

Amblyterodes Germain 1905:470 [original description in key to genera of Brachysternina]; Ohaus 1918:179 [placed in synonymy with Aulacopalpus]; Blackwelder 1944:247 [checklist as synonym of Aulacopalpus]; Machatschke 1965:61 [catalog listing as synonym of Aulacopalpus]; Machatschke 1972:305 [catalog listing as synonym of Aulacopalpus]; Smith 2002:this paper [Aulacopalpus viridis designated as type species, listing as synonym of Aulacopalpus].

Aegolasia Kolbe 1907:112 [original description]; Dalla Torre 1913:304 [catalog listing as Melolonthinae: Pachydemini]; Blackwelder 1944:227 [checklist as Melolonthinae: Pachydemini]; Martínez 1975:228 [placed in synonymy with Aulacopalpus]; Smith 2002: this paper [listing as synonym of Aulacopalpus].

Philadelphus (=Pseudadelphus, lapsus calami), Ohaus 1909:8 [key to species].

Aulacopalpus (Tribostethes), Ohaus 1918:179 [catalog listing, Tribostethes lowered to subgeneric status]; Blackwelder 1944:247 [checklist]; Gutiérrez 1949:30 [list of species]; Machatschke 1965:12, 62 [comment on distribution, catalog listing].

Aulacopalpus (Mimotribostethes) (improperly described, nomen nudum), Gutiérrez 1949:30 [incomplete description as a subgenus of Aulacopalpus, list of species]; Machatschke 1965:62 [catalog listing]; Machatschke 1972:306 [catalog listing]; Smith 2002: this paper [comment on nomenclature].

Mimotribostethes (improperly described, nomen nudum), Machatschke 1972:306 [elevated from subgeneric to generic status, catalog listing]; Morón 1995:195 [comment on distribution].

\section{Aulacopalpus aconcaguensis Smith, 2002}

Aulacopalpus aconcaguensis Smith 2002:this paper [phylogenetics, key to species of Aulacopalpus, original description, distribution]. 


\section{Aulacopalpus castaneus (Laporte, 1840)}

Brachysternus castaneus Laporte 1840:127 [original description]; Burmeister 1844: 462 [redescription]; Burmeister 1855:526 [list].

Tribostethes castaneus, Curtis 1845:448 [new combination, redescription]; Blanchard 1851:226 [catalog listing]; Harold 1869a:1231 [catalog listing]; Arrow 1899:369 [comparison with Pseudadelphus ciliatus]; Ohaus 1905:126, 139, 140, 165, 166 [redescription]; Ohaus 1909:6, 9, 12 [comment on morphology, key to species of Tribostethes]; Machatschke 1972:306 [cited as type species for Tribostethes, changed combination, catalog listing].

Bembegeneius fulvescens Solier 1851:85 [original description]; Philippi 1861:741 [comment]; Ohaus 1905:142, 165 [placed in synonymy with Tribostethes castaneus]; Ohaus 1909:20 [synonym of Tribostethes castaneus]; Ohaus 1918:180 [catalog listing as synonym of Aulacopalpus castaneus]; Blackwelder 1944:247 [checklist as synonym of Aulacopalpus castaneus]; Gutiérrez 1950:277 [synonym of Aulacopalpus castaneus]; Machatschke 1965:61, 63 [cited as type species for Bembegeneius, catalog listing as synonym of Aulacopalpus castaneus]; Machatschke 1972:305, 306 [cited as type species for Bembegeneius, catalog listing as synonym of Tribostethes castaneus]; Smith 2002: this paper [lectotype designation, listing as synonym of Aulacopalpus castaneus].

Tribosthetes castaneus (=Tribostethes castaneus, lapsus calami), Solier 1851:89 [redescription].

Brachysternus fulvescens, Blanchard 1851:226 [new combination, catalog listing]; Burmeister 1855:526 [list]; Lacordaire 1856:375 [list of species in Brachysternus]; Harold 1869a:1231 [catalog listing].

Tribostethus castaneus (=Tribostethes castaneus, lapsus calami), Lacordaire 1856:376 [cited as type species of Tribostethes]; Philippi 1861:741 [comment on distribution]; Philippi and Philippi 1864:320, 322 [comparison with Brachysternus chloris, Tribostethes virens, and Tribostethes cupreus].

Tribostethus cupreus (=Tribostethes cupreus, lapsus calami), Philippi and Philippi 1864:321 [original description].

Tribostethes cupreus, Harold 1869a:1231 [catalog listing]; Ohaus 1905:144, 165 [redescription]; Ohaus 1909:14 [placed in synonymy with Tribostethes castaneus]; Ohaus 1918:180 [catalog listing as synonym of Aulacopalpus castaneus]; Blackwelder 1944: 247 [checklist as synonym of Aulacopalpus castaneus]; Machatschke 1965:63 [catalog listing as synonym of Aulacopalpus castaneus]; Machatschke 1972:306 [catalog listing as synonym of Tribostethes castaneus]; Smith 2002:this paper [listing as synonym of Aulacopalpus castaneus].

Aulacopalpus fulvovirens Ohaus 1909:6, 9, 12, 16 [key to species of Aulacopalpus, original description]; Ohaus 1918:179 [catalog listing]; Blackwelder 1944:247 [checklist]; Smith 2002:this paper [placed in synonymy with Aulacopalpus castaneus, lectotype designated, listing as synonym of Aulacopalpus castaneus].

Aulacopalpus (Tribostethes) castaneus, Ohaus 1918:180 [new combination, catalog listing]; Gutiérrez 1949:31 [comment on morphology, locality data]; Machatschke 1965: 61, 63 [cited as type species for Tribostethes, catalog listing].

Aulacopalpus castaneus, Blackwelder 1944:247 [checklist]; Gutiérrez 1950:277 [nomenclature discussed]; Smith 2002:this paper [phylogenetics, key to species of Aulacopalpus, new combination, neotype designation, redescription, distribution].

Aulacopalpus (Mimotribostethes) fulvovirens (nomen nudum subgeneric name), Gutiérrez 1949:31 [new combination, comment on morphology, locality data]; Machatschke 1965:63 [catalog listing]. 
Mimotribostethes fulvovirens (nomen nudum generic name), Machatschke 1972:306 [new combination, catalog listing].

\section{Aulacopalpus ciliatus (Solier, 1851)}

Tribosthetes ciliatus (=Tribostethes ciliatus, lapsus calami) Solier 1851:89 [original description].

Tribostethes ciliatus, Blanchard 1851:226 [catalog listing]; Burmeister 1855:526 [comparison with Brachysternus castaneus]; Harold 1869a:1231 [catalog listing].

Tribostethus ciliatus (=Tribostethes ciliatus, lapsus calami), Lacordaire 1856:376 [list of species in Tribostethes]; Philippi 1861:741 [comment on distribution, morphology]; Philippi and Philippi 1864:320, 321 [comparison with Brachysternus chloris and Tribostethes virens, redescription].

Pseudadelphus ciliatus, Arrow 1899:369 [new combination].

Aulacopalpus ciliatus, Ohaus 1905:126, 130, 134, 143, 165, 166 [redescription, new combination]; Ohaus 1909:7, 8 [comment on morphology, key to species of Aulacopalpus]; Ohaus 1918:179 [catalog listing]; Blackwelder 1944:247 [checklist]; Gutiérrez 1949:31 [comment on morphology, locality data]; Machatschke 1965:61, 63 [cited as type species for Pseudadelphus, catalog listing]; Machatschke 1972:305 [cited as type species for Pseudadelphus, catalog listing]; Arias 2000:75 [comment on distribution, comment on morphology]; Smith 2002:this paper [phylogenetics, key to species of $\mathrm{Au}$ lacopalpus, lectotype designation, redescription, distribution].

\section{Aulacopalpus clypealis Ohaus, 1905}

Aulacopalpus clypealis Ohaus 1905:137, 141, 165, 166 [original description]; Ohaus 1909:8, 12 [key to species of Aulacopalpus, comment on morphology]; Ohaus 1918:179 [catalog listing]; Blackwelder 1944:247 [checklist]; Gutiérrez 1949:31 [comment on morphology, locality data]; Machatschke 1965:63 [catalog listing]; Machatschke 1972:305 [catalog listing]; Smith 2002:this paper [phylogenetics, key to species of Aulacopalpus, lectotype designated, redescription, distribution].

\section{Aulacopalpus pilicollis (Fairmaire, 1883)}

Tribostethes pilicollis Fairmaire 1883:491 [original description].

Aulacopalpus punctatus (misapplied), Ohaus 1905:125, 133, 138, 165, 166 [redescription, new combination]; Ohaus 1909:5, 8 [locality data, key to species of Aulacopalpus]; Gutiérrez 1947:313 [distribution]; Gutiérrez 1949:31 [comment on morphology, locality data].

Aulacopalpus pilicollis, Ohaus 1905:125, 134, 165, 166 [redescription, new combination]; Kolbe 1907:66 [catalog listing]; Ohaus 1909:4, 8 [locality data, key to species of Aulacopalpus]; Ohaus 1918:179 [catalog listing]; Blackwelder 1944:247 [checklist]; Gutiérrez 1947:313 [distribution]; Gutiérrez 1949:31 [comment on morphology, locality data]; Machatschke 1965:63 [catalog listing]; Machatschke 1972:306 [catalog listing] Zunino and Barbero 1991:142, 144, 145 [distribution]; Smith 2002:this paper [phylogenetics, key to species of Aulacopalpus, lectotype designation, redescription, distribution].

Aegolasia michaelseni Kolbe 1907:112 [original description]; Dalla Torre 1913:304 [catalog listing as Melolonthinae: Pachydemini]; Blackwelder 1944:227 [checklist as Melolonthinae: Pachydemini]; Smith 2002:this paper [neotype designation, placed in synonymy with Aulacopalpus pilicollis, listing as synonym of Aulacopalpus pilicollis]. 


\section{Aulacopalpus punctatus (Fairmaire and Germain, 1860)}

Tribostethes punctatus Fairmaire and Germain 1860:268 [original description]; Harold 1869a:1231 [catalog listing]; Fairmaire 1883:491 [compared to Tribostethes pilicollis].

Amblyterus variabilis Philippi 1861:742 [original description]; Smith 2002:this paper [placed in synonymy with Aulacopalpus punctatus, lectotype designated, listing as synonym of Aulacopalpus punctatus].

Aulacopalpus punctatus, Kolbe 1907:66 [catalog listing]; Ohaus 1918:179 [catalog listing]; Blackwelder 1944:247 [checklist]; Machatschke 1965:63 [catalog listing]; Machatschke 1972:306 [catalog listing]; Smith 2002:this paper [phylogenetics, key to species of Aulacopalpus, neotype designated, redescription, distribution].

Aulacopalpus variabilis, Ohaus 1905:126, 136, 139, 165, 166 [redescription, new combination]; Kolbe 1907:67 [catalog listing]; Ohaus 1909:8 [key to species of Aulacopalpus]; Ohaus 1918:179 [catalog listing]; Blackwelder 1944:247 [checklist]; Gutiérrez 1949:31 [comment on morphology, locality data]; Machatschke 1965:61, 63 [cited as type species for Amblyterodes, catalog listing]; Machatschke 1972:305, 306 [cited as types species for Amblyterodes, catalog listing].

\section{Aulacopalpus pygidialis Ohaus, 1905}

Aulacopalpus pygidialis Ohaus 1905:139, 165, 166 [original description]; Ohaus 1909: 6, 9, 12 [key to species of Aulacopalpus, comment on morphology]; Ohaus 1918:179 [catalog listing]; Blackwelder 1944:247 [checklist]; Smith 2002:this paper [phylogenetics, key to species of Aulacopalpus, lectotype designated, redescription, distribution].

Aulacopalpus (Mimotribostethes) pygidialis (nomen nudum subgeneric name), Gutiérrez 1949:31 [new combination, comment on morphology, locality data]; Machatschke 1965:63 [catalog listing].

Mimotribostethes pygidialis (nomen nudum generic name), Machatschke 1972:306 [cited as type species for Mimotribostethes, new combination, catalog listing].

\section{Aulacopalpus valdiviensis Smith, 2002}

Aulacopalpus valdiviensis Smith 2002:this paper [phylogenetics, key to species of Aulacopalpus, original description, distribution].

\section{Aulacopalpus viridis Guérin-Méneville, 1838}

Aulacopalpus viridis Guérin-Méneville 1838a:58 [original description]; Guérin-Méneville 1844:93 [redescription]; Burmeister 1844:459 [redescription]; Blanchard 1851: 226 [catalog listing]; Lacordaire 1856:376 [cited as type species of genus Aulacopalpus]; Philippi 1861:741 [comment on distribution, morphology]; Arrow 1899:367 [comparison with Hylamorpha]; Ohaus 1905:125, 129, 131, 165, 166 [redescription]; Ohaus 1909:7, 8, 11 [comment on morphology, key to species of Aulacopalpus]; Ohaus 1918:179 [catalog listing]; Blackwelder 1944:247 [checklist]; Gutiérrez 1949:31 [comment on morphology, locality data]; Machatschke 1965:62, 67 [catalog listing, cited as type species for Hylamorpha]; Machatschke 1972:305, 308 [cited as type species for Aulacopalpus and Hylamorpha, catalog listing]; Jameson and Smith 2002:this issue [comment on nomenclature]; Ratcliffe and Ocampo 2002:this issue [cited as type species for Sulcipalpus]; Smith 2002:this paper [phylogenetics, key to species of Aulacopalpus, designated as type species for Amblyterodes, neotype designation, redescription, distribution].

Aulocopalpus viridis (=Aulacopalpus viridis, lapsus calami), Solier 1851:92 [redescription]. 
Tribostethus virens (=Tribostethes virens, lapsus calami), Philippi and Philippi 1864: 320 [original description].

Tribostethes virens, Harold 1869a:1231 [catalog listing]; Ohaus 1905:130, 165 [placed in synonymy with Aulacopalpus viridis]; Ohaus 1909:11 [synonym of Aulacopalpus viridis]; Ohaus 1918:179 [catalog listing as synonym of Aulacopalpus viridis]; Blackwelder 1944:247 [checklist as synonym of Aulacopalpus viridis]; Machatschke 1965:62 [catalog listing as synonym of Aulacopalpus viridis]; Machatschke 1972:305 [catalog listing as synonym of Aulacopalpus viridis]; Smith 2002:this paper [neotype designated, listing as synonym of Aulacopalpus viridis].

Sulcipalpus viridis, Harold 1869a:1232 [new combination, catalog listing].

Aulacopalpus virens, Arrow 1899:368 [new combination].

Amblyterodes palpalis (nomen nudum) Ohaus 1909:11 [placed in synonymy with $A u$ lacopalpus viridis]; Ohaus 1918:179 [catalog listing as synonym of Aulacopalpus viridis]; Blackwelder 1944:247 [checklist as synonym of Aulacopalpus viridis]; Machatschke 1965:61, 62 [cited as type species for Melicurus, catalog listing as synonym of $\mathrm{Au}$ lacopalpus viridis]; Machatschke 1972:305 [cited as type species for Melicurus, catalog listing as synonym of Aulacopalpus viridis]; Smith 2002:this paper [comment on nomenclature, catalog listing as nomen nudum].

Hylamorpha viridis, Machatschke 1972:309 [erroneous combination, catalog listing].

\section{Genus Brachysternus Guérin-Méneville, 1831}

Brachysternus Guérin-Méneville 1831:3 [illustration, name made available by indication]; Guérin-Méneville 1838b:81 [original description]; Laporte 1840:127 [redescription]; Guérin-Méneville 1844:94 [type species cited as Brachysternus prasinus]; Burmeister 1844:432, 436, 459, 465 [redescription, key to genera of Anoplognathidae]; Blanchard 1845:218 [catalog listing]; Erichson 1847:100 [catalog listing]; Solier 1851: 86 [redescription]; Blanchard 1851:226 [catalog listing]; Burmeister 1855:526 [species list, comparison with Tribostethes]; Lacordaire 1856:372, 374 [key to genera of Brachysternides, redescription]; Philippi 1861:740 [distribution]; Philippi and Philippi 1864:322 [comparison with Aulacopalpus angustus]; Harold 1869a:1231 [catalog listing]; Ohaus 1904b:256, 258 [comparison with other genera of Anoplognathiden]; Germain 1905:451, 470 [redescription, compared to other genera of Brachysternidae, key to genera of Brachysternina, key to species]; Ohaus 1905:125, 127, 140, 145, 162, 165 [key to genera of Brachysternidae, redescription, species list]; Ohaus 1909:4, 9, 20 [discussion of nomenclature, key to species, species list]; Ohaus 1918:180 [catalog listing]; Blackwelder 1944:247 [checklist]; Machatschke 1965:13, 60, 64, 66 [distribution, key to genera of Brachysternina, catalog listing, redescription]; Machatschke 1972:307 [catalog listing]; Morón 1995:195 [comment on distribution]; Jameson and Smith 2002:this issue [revision, key to species, redescription, biology]; Ratcliffe and Ocampo 2002:this issue [comparison with Hylamorpha]; Smith 2002:this paper [phylogenetics, key to genera of Brachysternina].

Brachygaster (=Brachysternus, lapsus calami), Curtis 1845:449 [comment on morphology].

\section{Brachysternus angustus (Philippi and Philippi, 1864)}

Aulacopalpus angustus, Philippi and Philippi 1864:322 [original description].

Sulcipalpus angustus, Harold 1869a:1232 [new combination, catalog listing].

Brachysternus angustus Arrow 1899:368 [new combination]; Germain 1905:471, 477, 481 [key to species of Brachysternus, redescription]; Ohaus 1905:125, 145, 151, 159, 
160, 166, 167 [redescription]; Kolbe 1907:67 [catalog listing]; Ohaus 1909:4, 10, 15, 19 [locality data, key to species of Brachysternus, comment on morphology]; Ohaus 1918: 180 [catalog listing]; Blackwelder 1944:247 [checklist]; Gutiérrez 1947:313 [distribution]; Gutiérrez 1949:34 [list]; Machatschke 1965:65 [catalog listing]; Machatschke 1972:307 [catalog listing]; Jameson and Smith 2002:this issue [key to species of Brachysternus, redescription, distribution, biology]; Smith 2002:this paper [phylogenetics].

\section{Brachysternus germaini (Ohaus, 1909)}

Tribostethes germaini Ohaus 1909:6, 9, 14 [key to species of Tribostethes, original description]; Machatschke 1972:307 [new combination, catalog listing].

Aulacopalpus (Tribostethes) germaini, Ohaus 1918:180 [new combination, catalog listing]; Gutiérrez 1949:31 [comment on morphology, locality data]; Machatschke 1965:63 [catalog listing].

Aulacopalpus germaini, Blackwelder 1944:247 [checklist].

Brachysternus germaini, Jameson and Smith 2002:this issue [new combination, key to species of Brachysternus, neotype designated, redescription, distribution]; Smith 2002: this paper [phylogenetics].

\section{Brachysternus marginatus Germain, 1905}

Brachysternus marginatus Germain 1905:472, 485 [key to species of Brachysternus, original description]; Ohaus 1909:10 [key to species of Brachysternus]; Ohaus 1918:180 [catalog listing]; Blackwelder 1944:247 [checklist]; Machatschke 1965:65 [catalog listing]; Machatschke 1972:307 [catalog listing]; Jameson and Smith 2002:this issue [key to species of Brachysternus, lectotype designated, redescription, distribution]; Smith 2002:this paper [phylogenetics].

\section{Brachysternus olivaceus Philippi and Philippi, 1864}

Brachysternus olivaceus Philippi and Philippi 1864:318 [original description]; Harold 1869a:1231 [catalog listing]; Germain 1905:472, 493 [key to species of Brachysternus, redescription]; Ohaus 1905:145, 147, 153, 165, 167 [redescription]; Ohaus 1909:10, 16, 17 [key to species of Brachysternus, comment on morphology]; Ohaus 1918:180 [catalog listing]; Blackwelder 1944:247 [checklist]; Machatschke 1965:65 [catalog listing]; Machatschke 1972:307 [catalog listing]; Jameson and Smith 2002:this issue [key to species of Brachysternus, lectotype designated, redescription, distribution]; Smith 2002:this paper [phylogenetics].

Brachysternus chloris Philippi and Philippi 1864:319 [original description]; Harold 1869a:1231 [catalog listing]; Germain 1905:472, 504 [key to species of Brachysternus, redescription]; Ohaus 1905:149, 165 [redescription]; Ohaus 1909:11, 16, 17, 20 [key to species of Brachysternus, comment on morphology, synonymy with Brachysternus fulvescens suggested]; Ohaus 1918:180 [catalog listing]; Blackwelder 1944:247 [checklist]; Gutiérrez 1950:277 [nomenclature discussed]; Machatschke 1965:65 [catalog listing]; Machatschke 1972:307 [catalog listing]; Jameson and Smith 2002:this issue [lectotype designated, placed in synonymy with Brachysternus olivaceus].

Brachysternus fulvescens (misapplied), Germain 1905:471, 473 [key to species of Brachysternus, redescription]; Ohaus 1909:9, 17 [key to species of Brachysternus, comment on morphology]; Ohaus 1918:180 [catalog listing]; Blackwelder 1944:247 [checklist]; Gutiérrez 1950:277 [placed in synonymy with Brachysternus chloris]; Machatschke 1965:65 [catalog listing as synonym of Brachysternus chloris]; Machatschke 1972:307 [catalog listing as synonym of Brachysternus chloris]; Jameson and Smith 2002:this issue [comment on nomenclature]. 
Brachysternus riverae Germain 1905:472, 497, 501 [key to species of Brachysternus, original description]; Ohaus 1909:10 [key to species of Brachysternus]; Ohaus 1918:181 [catalog listing]; Blackwelder 1944:247 [checklist]; Machatschke 1965:65 [catalog listing]; Machatschke 1972:308 [catalog listing]; Jameson and Smith 2002:this issue [lectotype designated, placed in synonymy with Brachysternus olivaceus].

Brachysternus herbaceus Germain 1905:472, 499 [key to species of Brachysternus, original description]; Ohaus 1909:11, 16 [key to species of Brachysternus, comment on morphology]; Ohaus 1918:180 [catalog listing]; Blackwelder 1944:247 [checklist]; Machatschke 1965:65 [catalog listing]; Machatschke 1972:307 [catalog listing]; Jameson and Smith 2002:this issue [placed in synonymy with Brachysternus olivaceus].

Brachysternus prasinus araucanicus Ohaus 1905:156, 166 [original description as subspecies]; Machatschke 1965:66 [catalog listing as synonym of Brachysternus viridis]; Machatschke 1972:308 [catalog listing as synonym of Brachysternus viridis].

Brachysternus araucanicus, Ohaus 1909:18, 20 [placed in synonym with Brachysternus viridis]; Ohaus 1918:181 [catalog listing as synonym of Brachysternus viridis]; Blackwelder 1944:247 [checklist as synonym of Brachysternus viridis]; Jameson and Smith 2002:this issue [lectotype designated, placed in synonymy with Brachysternus olivaceus].

\section{Brachysternus patagoniensis Jameson and Smith, 2002}

Brachysternus patagoniensis Jameson and Smith 2002:this issue [key to species of Brachysternus, original description, distribution, biology]; Smith 2002:this paper [phylogenetics].

\section{Brachysternus prasinus Guérin-Méneville, 1831}

Brachysternus prasinus Guérin-Méneville 1831:3 [illustration, name made available by indication]; Guérin-Méneville 1838b:82 [original description]; Guérin-Méneville 1844:94 [cited as types species for Brachysternus]; Lacordaire 1856:374 [list of species in Brachysternus]; Philippi 1861:741 [comment on morphology]; Harold 1869a:1231 [catalog listing]; Germain 1905:472, 487, 497, 501 [key to species of Brachysternus, redescription]; Ohaus 1905:153, 154, 158, 163, 165, 167 [redescription]; Kolbe 1907:67 [catalog listing]; Ohaus 1909:5, 11, 17 [locality data, key to species of Brachysternus, comment on morphology]; Ohaus 1918:180 [catalog listing]; Blackwelder 1944:247 [checklist]; Machatschke 1965:65 [cited as type species for Brachysternus, catalog listing]; Machatschke 1965:65 [catalog listing]; Machatschke 1972:307 [cited as type species for Brachysternus, catalog listing]; Gentili and Gentili 1988:88, 89 [biology]; Jameson and Smith 2002:this issue [key to species of Brachysternus, neotype designated, redescription, distribution, biology]; Smith 2002:this paper [phylogenetics].

Brachysternus fulvipes Guérin-Méneville 1838a:61 [original description], Guérin-Méneville 1840:300 [comparison with Brachysternus vicinus]; Guérin-Méneville 1844:94 [redescription]; Burmeister 1844:461 [redescription]; Erichson 1847:100 [catalog listing]; Solier 1851:86 [comparison with Brachysternus viridis]; Blanchard 1851:226 [catalog listing as variety of Brachysternus viridis]; Burmeister 1855:526 [list]; Lacordaire 1856: 375 [list of species in Brachysternus]; Philippi 1861:741 [listed as possible synonym of Brachysternus prasinus]; Harold 1869a:1231 [catalog listing as variety of Brachysternus prasinus]; Ohaus 1905:165 [listed as variety of Brachysternus prasinus]; Ohaus 1918: 180 [catalog listing as variety of Brachysternus prasinus]; Blackwelder 1944:247 [checklist as variety of Brachysternus prasinus]; Machatschke 1965:65 [catalog listing as form of Brachysternus prasinus]; Machatschke 1972:307 [catalog listing as form of Brachysternus prasinus]; Jameson and Smith 2002:this issue [lectotype designated, listed as synonymy of Brachysternus prasinus]. 
Brachysternus vicinus Guérin-Méneville 1840:300 [original description]; Burmeister 1844:461 [redescription]; Solier 1851:86 [comparison with Brachysternus viridis]; Blanchard 1851:226 [catalog listing as variety of Brachysternus viridis]; Burmeister 1855: 526 [list]; Lacordaire 1856:375 [list of species in Brachysternus]; Philippi 1861:741 [listed as possible synonym of Brachysternus prasinus]; Harold 1869a:1231 [catalog listing as variety of Brachysternus prasinus]; Ohaus 1905:154, 166 [listed as possible synonym of Brachysternus prasinus]; Ohaus 1918:181 [catalog listing]; Blackwelder 1944:247 [checklist]; Machatschke 1965:66 [catalog listing]; Machatschke 1972:308 [catalog listing]; Jameson and Smith 2002:this issue [lectotype designated, placed in synonymy with Brachysternus prasinus].

Brachysternus viridis (=Brachysternus prasinus, lapsus calami), Laporte 1840:127 [redescription]; Burmeister 1844:460 [redescription]; Solier 1851:87 [redescription]; Blanchard 1851:226 [catalog listing]; Burmeister 1855:526 [list]; Lacordaire 1856:375 [list of species in Brachysternus]; Philippi 1861:741 [comment on nomenclature]; Philippi and Philippi 1864:319 [comparison with Brachysternus chloris]; Harold 1869a:1231 [catalog listing as synonym of Brachysternus prasinus]; Germain 1905:487 [comment on nomenclature]; Ohaus 1918:180 [catalog listing as synonym of Brachysternus prasinus]; Blackwelder 1944:247 [checklist as synonym of Brachysternus prasinus]; Machatschke 1965:65 [catalog listing as synonym of Brachysternus prasinus]; Machatschke 1972:307 [catalog listing as synonym of Brachysternus prasinus]; Jameson and Smith 2002:this issue [comment on nomenclature].

Brachystemus prasinus (=Brachysternus prasinus, lapsus calami), Curtis 1845:449 [comment on morphology].

Tribostethes vicinus, Harold 1869a:1231 [new combination, catalog listing, placed in synonym with Tribostethes castaneus].

Brachysternus sinuatifrons Germain 1905:471, 475 [key to species of Brachysternus, original description]; Ohaus 1909:10, 19 [key to species of Brachysternus]; Ohaus 1918: 181 [catalog listing]; Blackwelder 1944:247 [checklist]; Gutiérrez 1950:278 [nomenclature discussed]; Machatschke 1965:65 [catalog listing]; Machatschke 1972:308 [catalog listing]; Jameson and Smith 2002:this issue [placed in synonymy with Brachysternus prasinus].

Brachysternus viridis Germain 1905:472, 487, 494, 496, 497, 501, 503 [key to species of Brachysternus, original designation as an available name, redescription]; Ohaus 1909: 10 [key to species of Brachysternus]; Ohaus 1918:181 [catalog listing]; Blackwelder 1944:247 [checklist]; Gutiérrez 1947:313 [distribution]; Gutiérrez 1949:34 [list]; Machatschke 1965:66 [catalog listing]; Machatschke 1972:308 [catalog listing]; Arias 2000: 75 [comment on distribution, comment on morphology]; Jameson and Smith 2002:this issue [lectotype designated, placed in synonymy with Brachysternus prasinus].

Brachysternus pubescens Germain 1905:472, 495 [key to species of Brachysternus, original description]; Ohaus 1909:10, 17 [key to species of Brachysternus, comment on morphology]; Ohaus 1918:181 [catalog listing]; Blackwelder 1944:247 [checklist]; Machatschke 1965:65 [catalog listing]; Machatschke 1972:307 [catalog listing]; Jameson and Smith 2002:this issue [lectotype designated, placed in synonymy with Brachysternus prasinus].

Brachysternus dilatatus Germain 1905:472, 502 [key to species of Brachysternus, original description]; Ohaus 1909:11, 19, 20 [key to species of Brachysternus, comment on morphology, synonymy with Brachysternus sinuatifrons suggested]; Ohaus 1918:180 [catalog listing]; Blackwelder 1944:247 [checklist]; Gutiérrez 1950:278 [placed in synonymy with Brachysternus sinuatifrons]; Machatschke 1965:66 [catalog listing as synonym of Brachysternus sinuatifrons]; Machatschke 1972:308 [catalog listing as synonym of Brachysternus sinuatifrons]; Jameson and Smith 2002:this issue [lectotype designated, placed in synonymy with Brachysternus prasinus].

Brachysternus prasinus viridipes Ohaus 1905:157, 166 [original description as sub- 
species]; Machatschke 1965:66 [catalog listing as synonym of Brachysternus sinuatifrons]; Machatschke 1972:308 [catalog listing as variety of Brachysternus sinuatifrons].

Brachysternus hirtus Ohaus 1905:158, 165, 167 [original description]; Ohaus 1909: 17 [placed in synonymy with Brachysternus pubescens]; Ohaus 1918:181 [catalog listing as synonym of Brachysternus pubescens]; Blackwelder 1944:247 [checklist as synonym of Brachysternus pubescens]; Machatschke 1965:65 [catalog listing as synonym of Brachysternus pubescens]; Machatschke 1972:308 [catalog listing as synonym of Brachysternus pubescens]; Jameson and Smith 2002:this issue [lectotype designated, placed in synonymy with Brachysternus prasinus].

Brachysternus viridipes, Ohaus 1909:19, 21 [placed in synonymy with Brachysternus dilatatus]; Ohaus 1918:180 [catalog listing as synonym of Brachysternus dilatatus]; Blackwelder 1944:247 [checklist as synonym of Brachysternus dilatatus]; Gutiérrez 1950:278 [synonym of Brachysternus sinuatifrons]; Jameson and Smith 2002:this issue [lectotype designated, placed in synonymy with Brachysternus prasinus].

\section{Brachysternus spectabilis Erichson, 1847}

Brachysternus spectabilis Erichson 1847:100 [original description]; Blanchard 1851: 226 [comparison with Brachysternus viridis]; Burmeister 1855:526 [list]; Lacordaire 1856:375 [list of species in Brachysternus]; Harold 1869a:1231 [catalog listing]; Ohaus 1905:149, 159, 161, 165, 167 [redescription]; Kolbe 1907:67 [catalog listing]; Ohaus 1909:19 [comment on morphology]; Ohaus 1918:181 [catalog listing]; Blackwelder 1944:247 [checklist]; Gutiérrez 1947:313 [distribution]; Gutiérrez 1949:34 [list]; Machatschke 1965:66, 145 [catalog listing, illustration]; Machatschke 1972:308 [catalog listing]; Arias 2000:75 [comment on distribution, comment on morphology]; Jameson and Smith 2002:this issue [key to species of Brachysternus, lectotype designated, redescription, distribution]; Smith 2002:this paper [phylogenetics].

Brachysternus obscurus Philippi and Philippi 1864:317 [original description]; Harold 1869a:1231 [catalog listing]; Germain 1905:481 [placed as synonym of Brachysternus philippii]; Ohaus 1905:150, 165 [placed as form of Brachysternus spectabilis]; Ohaus 1909:19 [placed as synonym of Brachysternus spectabilis]; Ohaus 1918:181 [catalog listing as synonym of Brachysternus spectabilis]; Blackwelder 1944:247 [checklist as synonym of Brachysternus spectabilis]; Machatschke 1965:66 [catalog listing as synonym of Brachysternus spectabilis]; Machatschke 1972:308 [catalog listing as synonym of Brachysternus spectabilis]; Jameson and Smith 2002:this issue [lectotype designated, listed as synonym of Brachysternus spectabilis].

Brachysternus major Philippi and Philippi 1864:317 [original description]; Harold 1869a:1231 [catalog listing]; Germain 1905:481 [placed as synonym of Brachysternus philippii]; Ohaus 1905:150, 156, 159, 165 [listed as form of Brachysternus spectabilis]; Ohaus 1909:19 [placed as synonym of Brachysternus spectabilis]; Ohaus 1918:181 [catalog listing as synonym of Brachysternus spectabilis]; Blackwelder 1944:247 [checklist as synonym of Brachysternus spectabilis]; Machatschke 1965:66 [catalog listing as synonym of Brachysternus spectabilis]; Machatschke 1972:308 [catalog listing as synonym of Brachysternus spectabilis]; Jameson and Smith 2002:this issue [lectotype designated, listed as synonym of Brachysternus spectabilis].

Brachysternus philippii Germain 1905:471, 481, 483 [key to species of Brachysternus, original description]; Ohaus 1909:10, 19 [key to species of Brachysternus, placed in synonymy with Brachysternus spectabilis]; Ohaus 1918:181 [catalog listing as synonym of Brachysternus spectabilis]; Blackwelder 1944:247 [checklist as synonym of Brachysternus spectabilis]; Machatschke 1965:66 [catalog listing as synonym of Brachysternus spectabilis]; Machatschke 1972:308 [catalog listing as synonym of Brachysternus spectabilis]; Jameson and Smith 2002:this issue [lectotype designated, listed as synonym of Brachysternus spectabilis]. 


\title{
Genus Hylamorpha Arrow, 1899
}

\author{
Callichloris (misapplied), Curtis 1845:449 [redescription].
}

Hylamorpha Arrow 1899:368 [original description]; Ohaus 1904b:256, 258 [comparison with other genera of Anoplognathiden]; Germain 1905:478 [comment on nomenclature]; Ohaus 1905:125, 127, 140, 162, 166 [key to genera of Brachysternidae, redescription, species list]; Ohaus 1909:6, 11, 21 [discussion of nomenclature, key to species, species list]; Ohaus 1918:181 [catalog listing]; Blackwelder 1944:247 [checklist]; Machatschke 1965:13, 60, 66 [distribution, key to genera of Brachysternina, catalog listing, redescription]; Machatschke 1972:308 [catalog listing]; Morón 1995:195 [comment on distribution]; Jameson and Smith 2002:this issue [comparison with Brachysternus]; Ratcliffe and Ocampo 2002:this issue [discussion of nomenclature, type species designation, redescription]; Smith 2002:this paper [phylogenetics, key to genera of Brachysternina].

Sulcipalpus (misapplied), Germain 1905:451, 470 [comparison with other genera of Brachysternina, key to genera of Brachysternina].

\section{Hylamorpha elegans (Burmeister, 1844)}

Aulacopalpus elegans Burmeister 1844:459 [original description]; Blanchard 1851:225 [catalog listing]; Burmeister 1855:526 [Callichloris perelegans placed as junior synonym]; Lacordaire 1856:376 [list of species in Aulacopalpus]; Philippi 1861:741 [comment on distribution, morphology]; Philippi and Philippi 1864:319 [comparison with Brachysternus chloris]; Germain 1905:478 [comment on nomenclature].

Callichloris perelegans Curtis 1845:449 [original description]; Solier 1851:91 [placed in synonymy with Aulacopalpus elegans]; Blanchard 1851:225 [catalog listing as synonym of Aulacopalpus elegans]; Burmeister 1855:526 [synonym of Aulacopalpus elegans]; Philippi 1861:741 [listed as synonym of Aulacopalpus elegans]; Ohaus 1918:181 [catalog listing as synonym of Hylamorpha elegans]; Blackwelder 1944:247 [checklist as synonym of Hylamorpha elegans]; Machatschke 1965:67 [catalog listing as synonym of Hylamorpha elegans]; Machatschke 1972:309 [catalog listing as synonym of Hylamorpha elegans]; Ratcliffe and Ocampo 2002:this issue [lectotype designation, synonym of Hylamorpha elegans].

Aulocopalpus elegans (=Aulacopalpus elegans, lapsus calami), Solier 1851:91 [redescription].

Aulacopalpus elegans australis (variety, unavailable name), Philippi 1861:741 [description as variety]; Ratcliffe and Ocampo 2002:this issue [comment on nomenclature].

Sulcipalpus elegans, Harold 1869a:1232 [new combination, catalog listing]; Machatschke 1972:305, 306 [cited as type species for Sulcipalpus, catalog listing].

Sulcipalpus perelegans, Harold 1869a:1232 [catalog listing as synonym of Sulcipalpus elegans].

Sulcipalpus subviolaceus Nonfried 1894:125 [original description]; Arrow 1901:401 [placed in synonymy with Hylamorpha elegans]; Ohaus 1918:181 [catalog listing as synonym of Hylamorpha elegans]; Machatschke 1972:309 [catalog listing as synonym of Hylamorpha elegans]; Ratcliffe and Ocampo 2002:this issue [synonym of Hylamorpha elegans].

Hylamorpha viridis (=Hylamorpha elegans, lapsus calami), Arrow 1899:368 [new combination]; Jameson and Smith 2002: this issue [comment on nomenclature].

Hylamorpha elegans, Arrow 1899:368 [new combination]; Arrow 1901:400 [comment on morphology]; Ohaus 1905:125, 160, 163, 164, 166, 167 [redescription]; Kolbe 1907: 67 [catalog listing]; Ohaus 1909:11 [key to species of Hylamorpha]; Ohaus 1918:181 [catalog listing]; Blackwelder 1944:247 [checklist]; Gutiérrez 1947:313 [distribution]; 
Gutiérrez 1949:35 [list]; Machatschke 1965:66, 67 [cited as type species for Aulacopalpus and Sulcipalpus, catalog listing]; Machatschke 1972:309 [catalog listing]; Carrillo and Cerda 1987:100 [biology]; Gentili and Gentili 1988:88 [biology]; Glare et al. 1993 [fungal pathogen]; Veblen et al. 1996:315, 316 [biology]; Arias 2000:75 [comment on distribution, comment on morphology]; Ratcliffe and Ocampo 2002:this issue [neotype designation, redescription, distribution, biology]; Smith 2002:this paper [phylogenetics, comment on nomenclature].

Hylamorpha rufimana Arrow 1899:368 [original description]; Arrow 1901:400 [placed in synonymy with Hylamorpha elegans]; Germain 1905:478 [comment on nomenclature]; Ohaus 1909:21 [placed in synonymy with Hylamorpha elegans]; Ohaus 1918:181 [catalog listing as synonym of Hylamorpha elegans]; Blackwelder 1944:247 [checklist as synonym of Hylamorpha elegans]; Machatschke 1965:67 [catalog listing as synonym of Hylamorpha elegans]; Machatschke 1972:309 [catalog listing as synonym of Hylamorpha elegans]; Ratcliffe and Ocampo 2002:this issue [lectotype designation, synonym of Hylamorpha elegans].

Hylamorpha cylindrica Arrow 1899:368 [original description]; Germain 1905:478 [comment on nomenclature]; Ohaus 1905:126, 164, 166 [redescription]; Ohaus 1909:11 [key to species of Hylamorpha]; Ohaus 1918:181 [catalog listing]; Blackwelder 1944: 247 [checklist]; Machatschke 1965:67 [catalog listing]; Machatschke 1972:309 [catalog listing]; Ratcliffe and Ocampo 2002:this issue [lectotype designation, placed in synonymy with Hylamorpha elegans].

Brachysternus subviolaceus, Ohaus 1905:124, 165 [new combination, placed in synonymy with Brachysternus prasinus].

Hylamorpha subviolacea (=Sulcipalpus subviolaceus), Blackwelder 1944:247 [checklist as synonym of Hylamorpha elegans].

Hylamorpha subviolaceus, Machatschke 1965:67 [catalog listing as synonym of Hylamorpha elegans].

Hylamorpha cilindrica (=Hylamorpha cylindrica, lapsus calami), Cartagena 1975:165 [biology].

\section{Acknowledgments}

I am very grateful to Pedro Vidal who provided a wealth of information and specimens that greatly augmented this paper. I acknowledge Mario Elgueta and Elizabeth Arias for taking time to answer my questions about Chilean entomology collections, collecting localities, and Philippi and Germain type material. I thank the individuals and institutions from which specimens were borrowed for making material available to me for study. I am especially grateful to Henry Howden and the CMNC for allowing me unlimited access to the voluminous "Martínez collection" because those specimens formed the cornerstone of this revision. I thank Al Newton of the FMNH and Bob Anderson and François Génier of the CMNC for allowing me to distribute paratypes of the two new species to other collections, and the USNM for the long-term loan of all the "higher scarabs" to the University of Nebraska State Museum for off-site enhancement. Dan Schmidt and Angie Fox are gratefully acknowledged for the excellent carbon dust habitus illustration and distribution maps respectively. Many thanks to Federico Ocampo for indispensable help in securing loans from Argentinean institutions, translating the keys to Spanish, and interpreting locality data. Thanks also to Aura Paucar for translating the abstract to Spanish and to Art Evans for being my all-knowing melolonthine guru. Much appreciation to Ben Hanelt and Paul Lago for translations of various passages and articles. Mary Liz Jameson and Brett Ratcliffe made con- 
tributions through our many discussions and debates about various aspects of our joint Brachysternina project, and my manuscript was greatly improved through their reviews. Mary Liz Jameson is acknowledged for composing the color photograph of the Brachysternina. This project was supported by an NSF/ PEET grant (DEB-9712447) to B. C. Ratcliffe and M. L. Jameson.

\section{Literature Cited}

Arias, E. T. 2000. Coleopteros de Chile/Chilean Beetles. Fototeknika, Santiago de Chile. $209 \mathrm{pp}$.

Arrow, G. J. 1899. On the classification of the coleopterous family Rutelidae. The Annals and Magazine of Natural History (series 4) 7:363-370.

Arrow, G. J. 1901. Remarks on the secondary sexual differences in rutelid Coleoptera, with descriptions of some new forms. The Annals and Magazine of Natural History (series 7) 7:393-401.

Blackwelder, R. E. 1944. Checklist of the coleopterous insects of Mexico, Central America, the West Indies, and South America. Part 2. United States National Museum Bulletin 185:189-341.

Blanchard, C. É. 1845. Histoire Naturelle des Insectes, Leurs Moeurs, Leurs Métamorphoses et Leur Classification ou Traité Élémentaire d'Entomologie, vol. 1. Librairie F. Savy, Paris. 398 pp.

Blanchard, C. É. 1851. Ordre des Coleoptera [pp. 129-240]. In: Muséum d'Histoire Naturelle de Paris. Catalogue de la Collection Entomologique. Classe des Insectes. vol. 1, part 2 (H. Milne-Edwards, C. É. Blanchard, and H. Lucus, editors). Gide and Baudry, Paris.

Browne, J., and C. H. Scholtz. 1998. Evolution of the scarab hindwing articulation and wing base: a contribution toward the phylogeny of the Scarabaeidae (Scarabaeoidea: Coleoptera). Systematic Entomology 23:307-326.

Browne, J., and C. H. Scholtz. 1999. A phylogeny of the families of Scarabaeoidea (Coleoptera). Systematic Entomology 24:51-84.

Burmeister, H. 1844. Handbuch der Entomologie, vol. 4, part 1. T. C. F. Enslin, Berlin. $586 \mathrm{pp}$.

Burmeister, H. 1855. Handbuch der Entomologie, vol. 4, part 2. T. C. F. Enslin, Berlin. $569 \mathrm{pp}$.

Carrillo, R., and L. Cerda. 1987. Zoofitofagos en Nothofagus Chilenos. Bosque 8(2): 99-103.

Cartagena, L. 1975. Crianza y reproduccion de Hylamorpha cilindrica Arr (Col. Scarabaeidae) en cuatro texturas de suelos. Revista Chilena de Entomología 9:165166.

Clapperton, C. M. 1993. Nature of environmental changes in South America during the last glacial maximum. Palaeogeography, Palaeoclimatology, Palaeoecology 101: 189-208.

Curtis, J. 1845. Descriptions, \&c. of the insects collected by Captain P. P. King, R. N., F. R. S. \& L. S., in the survey of the Straits of Magellan. Transactions of the Linnean Society of London 19:441-475.

Dalla Torre, K. W. 1913. Scarabaeidae; Melolonthinae IV. Coleopterorum Catalogus 50:291-450.

Erichson, W. F. 1847. Conspectus Insectorum Coleopterorum quae in Republica Peruana observata sunt. Archiv für Naturgeschichte 13:67-185.

Evenhuis, N. L. 1997. Litteratura Taxonomica Dipterorum (1758-1930), vol. 2. Backhuys Publishers, Leiden. Pp. 427-871.

Fairmaire, L. 1883. Coléoptères de Magellan et de Santa-Cruz. Annales de la Société Entomologique de France (series 6) 3:483-506.

Fairmaire, L., and P. Germain. 1860. Coleoptera Chilensis. Revue Zoologique (second series) 12:267-269.

Farrell, B. D. 1998. "Inordinate fondness" explained: why are there so many beetles? Science 281:555-559. 
Farris, J. S. 1969. A successive approximations approach to character weighting. Systematic Zoology 18:374-385.

Gentili, M., and P. Gentili. 1988. Lista comentada de los insectos asociados a las especies Sudamericanas del genero Nothofagus. Monografias de la Academia Nacional de Ciencias Exactas, Fisicas y Naturales Buenos Aires 4:85-106.

Germain, P. 1905. Apuntes entomolójicos. Anales de la Universidad, Republica de Chile 115:449-506. ["1904"].

Germain, P. 1911. Catálogo de los coleopteros chilenos del Museo Nacional. Boletin del Museo Nacional de Chile 3(1):47-73.

Glare, T. R., T. A. Jackson, and E. Cisternas. 1993. Beauveria vermiconia is an entomopathogenic fungus. Mycological Research 97:336-338.

Guérin-Méneville, F. E. 1831. Insectes. In: Voyage Autour du Monde, Exécuté par Ordre du Roi, sur la Corvette de la Majesté, la Coquille, Pendant les Années $1822,1823,1824$ et 1825 , sous le Ministère et Conformément aux Instructions de S. E. M. Le Marquis de Clermont-Tonnerre, Ministre de la Marine; et Publié sous les Auspices de son Excellence Mgr le Cte de Chabrol, Ministre de la Marine et des Colonies, Atlas (Histoire naturelle, Zoologie) (M. L. I. Duperrey, editor). Arthus Bertrand, Paris. 21 plates.

Guérin-Méneville, F. E. 1838a. Insectes du voyage de la Favorite. Magasin de Zoologie 8(9): $1-80$

Guérin-Méneville, F. E. 1838b. Insectes. Chapter 13 [pp. 57-302]. In: Voyage Autour du Monde, Exécuté par Ordre du Roi, sur la Corvette de la Majesté, la Coquille, Pendant les Années 1822, 1823, 1824 et 1825, sous le Ministère et Conformément aux Instructions de S. E. M. Le Marquis de Clermont-Tonnerre, Ministre de la Marine; et Publié sous les Auspices de son Excellence Mgr le Cte de Chabrol, Ministre de la Marine et des Colonies, vol. 2, Part 2 (Zoologie, M. Lesson editor), Division 1 (M. L. I. Duperrey, editor). Arthus Bertrand, Paris. 319 pp. [“1830”].

Guérin-Méneville, F. E. 1840. Description de quelques Coléoptères des côtes du détroit de Magellan. Revue Zoologique 1840:295-305.

Guérin-Méneville, F. E. 1844. Iconographie du Règne Animal de G. Cuvier, ou Représentation d'après Nature de L'une des Espèces les plus Remarquables et souvent non encore Figurees, de Chaque Genre d'Animaux, vol. 3. J. B. Baillière, Paris. $576 \mathrm{pp}$.

Gutiérrez, R. 1947. Escarabajos comunes a Chile y la Argentina (Col. Scarabaeidae). Revista de la Sociedad Entomológica Argentina 13:309-314.

Gutiérrez, R. 1949. Notas sobre Scarabaeidae Neotropicos. Anales de la Sociedad Científica Argentina 148:9-35.

Gutiérrez, R. 1950. Notas sobre Scarabaeidae Chilenos (Coleoptera Lamellicornia). Arthropoda 1(2/4):267-278.

Gutiérrez, R. 1951. Notas sobre Scarabaeidae Neotropicos II. Anales de la Sociedad Científica Argentina 151:105-125.

Harold, E. 1869a. Scarabaeidae [pp. 979-1346]. In: Catalogus Coleopterorum Hucusque Descriptorum Synonymicus et Systematicus, vol. 4 (M. Gemminger and E. Harold, editors). E. H. Gummi, Monachii.

Harold, E. 1869b. Abänderungen vergebener Namen. Coleopterologische Hefte 5:122125 .

Hill, R. S., and M. E. Dettmann. 1996. Origin and diversification of the genus Nothofagus. Ch. 2 [pp. 11-24]. In: The ecology and biogeography of Nothofagus forests. Yale University Press, New Haven. 403 pp.

Howden, H. F. 1981. Zoogeography of some Australian Coleoptera as exemplified by the Scarabaeoidea [pp. 1009-1035]. In: Ecological biogeography of Australia (A. Keast, editor). Dr. W. Junk Publishers, The Hague.

Howden, H. F. 1982. Larval and adult characteristics of Frickius Germain, its relationship to the Geotrupini, and a phylogeny of some major taxa in the Scarabaeoidea (Insecta: Coleoptera). Canadian Journal of Zoology 60:2713-2724.

International Commission on Zoological Nomenclature. 1999. International Code of Zoological Nomenclature, Fourth Edition. International Commission on Zoological Nomenclature, The Natural History Museum, London. 306 pp.

Jameson, M. L. 1998. Phylogenetic analysis of the subtribe Rutelina and revision of 
the Rutela generic groups (Coleoptera: Scarabaeidae: Rutelinae: Rutelini). Bulletin of the University of Nebraska State Museum 14:1-184. ["1997"].

Jameson, M. L., and A. B. T. Smith. 2002. Revision of the South American genus Brachysternus Guérin-Méneville (Coleoptera: Scarabaeidae: Rutelinae: Anoplognathini: Brachysternina). Coleopterists Bulletin 56:321-366.

Kolbe, H. 1907. Coleopteren. Ergebnisse der Hamburger Magalhaensische Sammelreise $8: 1-125$.

Lacordaire, J. T. 1856. Histoire Naturelle des Insectes. Genera des Coléoptères, vol. 3. Librairie Encyclopédique de Roret, Paris. 594 pp.

Laporte, F. L. (Comte de Castelnau). 1840. Histoire Naturelle des Insectes Coléoptères (Volume 2 of Histoire Naturelle des Animaux Articulés). P. Duménil, Paris. 564 pp.

Linder, H. P., and M. D. Crisp. 1995. Nothofagus and Pacific biogeography. Cladistics 11:5-32.

Machatschke, J. W. 1965. Coleoptera Lamellicornia. fam. Scarabaeidae, subfam. Rutelinae, section Rutelinae Orthochilidae. Genera Insectorum 199' $: 1-145$.

Machatschke, J. W. 1972. Scarabaeoidea: Melolonthidae, Rutelinae. Coleopterorum Catalogus Supplementa 66(1):1-361.

Maddison, D. R., and W. P. Maddison. 2000. MacClade. Version 4.0. Sinauer Associates, Sunderland, Massachusetts.

Markgraf, V., E. Romero, and C. Villagrán. 1996. History and paleoecology of South American Nothofagus forests [pp. 354-386]. In: The ecology and biogeography of Nothofagus forests (T. T. Veblen, R. S. Hill, and J. Read, editors). Yale University Press, New Haven. 403 pp.

Martínez, A. 1975. Contribución al conocimiento de los Pachydemini neotropicales (Col. Scarabaeidae, Melolonthinae). Entomologischen Arbeiten aus dem Museum G. Frey 26:227-251.

Meier, R., P. Kores, and S. Darwin. 1991. Homoplasy slope ratio: a better measurement of observed homoplasy in cladistic analyses. Systematic Zoology 40:74-88.

Mercer, J. H. 1976. Glacial history of southernmost South America. Quaternary Research 6:125-166.

Morón, M. A. 1995. Las especies mexicanas de Phalangogonia Burmeister (Coleoptera: Melolonthidae, Rutelinae). Giornale Italiano di Entomologia 7:195-202.

Morrone, J. J. 1999. Presentacion preliminar de un nuevo esquema biogeografico de America del sur. Biogeographica 75:1-16.

Morrone, J. J., L. Katinas, and J. V. Crisci. 1997. A cladistic biogeographic analysis of Central Chile. Journal of Comparative Biology 2:25-42.

Newton, A. F. 1985. South temperate Staphylinoidea (Coleoptera) their potential for biogeographic analysis of austral disjuctions, [pp. 180-220]. In: Taxonomy, phylogeny and zoogeography of beetles and ants (G. E. Ball, editor). Dr. W. Junk, Dordrecht. 514 pp.

Nonfried, A. F. 1894. Beschreibungen neuer Lamellicornier, Buprestiden und Cerambyciden aus Central- und Süd-Amerika. Entomologische Nachrichten 20:113-128.

Ohaus, F. 1904a. Revision der Anoplognathiden (Coleoptera lamellicornia). Stettiner Entomologische Zeitung 65:57-175.

Ohaus, F. 1904b. Revision der amerikanischen Anoplognathiden (Coleoptera lamellicornia). Stettiner Entomologische Zeitung 65:254-341.

Ohaus, F. 1905. Revision der amerikanischen Anoplognathiden (Coleoptera lamellicornia). Stettiner Entomologische Zeitung 66:120-167.

Ohaus, F. 1909. Nachträge und Berichtigungen zu meiner Revision der Brachysterniden (Coleopt. lamellicornia). Stettiner Entomologische Zeitung. 71:3-26. ["1910"].

Ohaus, F. 1918. Scarabaeidae: Euchirinae, Phaenomerinae, Rutelinae. Coleopterorum Catalogus 20:1-241. [“1915"].

Philippi, F. 1861. Observaciones sobre los lamelicornios de Chile, descritos en la obra del Señor Gay, con descripcion de algunas especies nuevas. Anales de la Universidad, Republica de Chile 18:735-742.

Philippi, R. A., and F. Philippi. 1864. Beschreibung einiger neuen Chilenischen Käfer. Stettiner Entomologische Zeitung 25:313-406.

Ratcliffe, B. C., and F. Ocampo. 2002. A review of the genus Hylamorpha Arrow 
(Coleoptera: Scarabaeidae: Rutelinae: Anoplognathini: Brachysternina). Coleopterists Bulletin 56:367-378.

Scholtz, C. H., and S. L. Chown. 1995. The evolution of habitat use and diet in the Scarabaeoidea: a phylogenetic approach (pp. 356-374). In: Biology, phylogeny, and classification of Coleoptera: papers Celebrating the 80th Birthday of Roy A. Crowson (J. Pakaluk and S. A. Slipinski, editors). Muzeum i Instytut Zoologii PAN, Warszawa, Poland. 1092 pp.

Solier, A. J. J. 1851. Orden III. Coleopteros [pp. 5-285]. In: Historia Fisica y Politica de Chile. Zoología, vol. 5 (C. Gay, editor). C. Gay, Paris. 564 pp.

Swenson, U., A. Backlund, S. McLoughlin, and R. S. Hill. 2001. Nothofagus biogeography revisited with special emphasis on the enigmatic distribution of subgenus Brassospora in New Caledonia. Cladistics 17:28-47.

Swofford, D. L. 2000. PAUP*. Phylogenetic Analysis Using Parsimony (* and Other Methods). Version 4. Sinauer Associates, Sunderland, Massachusetts.

Thayer, M. K. 1985. Revision, phylogeny and biogeography of the austral genus $\mathrm{Me}$ tacorneolabium Steel (Coleoptera: Staphylinidae: Omaliinae) [pp. 113-179]. In: Taxonomy, phylogeny and zoogeography of beetles and ants (G. E. Ball, editor). Dr. W. Junk, Dordrecht. 514 pp.

Veblen, T. T., C. Donoso, T. Kitzberger, and A. J. Rebertus. 1996. Ecology of southern Chilean and Argentinian Nothofagus forests [pp. 293-353]. In: The ecology and biogeography of Nothofagus forests (T. T. Veblen, R. S. Hill, and J. Read, editors). Yale University Press, New Haven. 403 pp.

Wilf, P., C. C. Labandeira, W. J. Kress, C. L. Staines, D. M. Windsor, A. L. Allen, and K. R. Johnson. 2000. Timing the radiations of leaf beetles: hispines on gingers from latest Cretaceous to Recent. Science 289:291-294.

Zunino, M., and E. Barbero. 1991. Note su alcuni Scarabaeoidea (Coleoptera) della Terra del Fuoco [pp. 142-147]. In: Atti del Primo Convegno di Biologia Antartica. Edizioni Universitarie Patavine, Padova (B. Battaglia, P. M. Bisol, and V. Varotto, editors). 408 pp.

(Received 11 December 2000; accepted 22 August 2001)

Appendix 1. Character matrix used in the phylogenetic analysis of the Brachysternina.

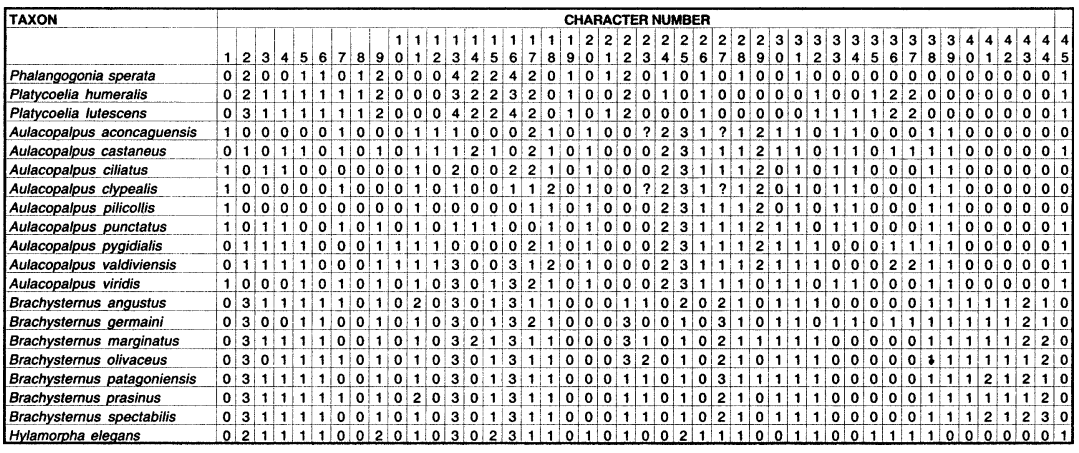

